\title{
AVALIAÇÃO RADIOGRÁFICA COMPARATIVA DA REABSORÇÃO RADICULAR APICAL APÓS O TRATAMENTO COM O APARELHO DE FRÄNKEL E OS GUIAS DE ERUPÇÃO
}

\section{ALEXANDRE YUDY NAKAMURA}

\begin{abstract}
Dissertação apresentada à Faculdade de Odontologia de Bauru da Universidade de São Paulo, como parte dos requisitos para obtenção do grau de mestre em Odontologia, área de Ortodontia
\end{abstract}

(Edição Revisada)

\section{BAURU}




\title{
AVALIAÇÃO RADIOGRÁFICA COMPARATIVA DA REABSORÇÃO RADICULAR APICAL APÓS O TRATAMENTO COM O APARELHO DE FRÄNKEL E OS GUIAS DE ERUPÇÃO
}

\section{ALEXANDRE YUDY NAKAMURA}

\begin{abstract}
Dissertação apresentada à Faculdade de Odontologia de Bauru da Universidade de São Paulo, como parte dos requisitos para obtenção do grau de mestre em Odontologia, área de Ortodontia
\end{abstract}

(Edição Revisada)

Orientador: Prof. Dr. Guilherme Janson

\section{BAURU}




\begin{tabular}{|c|c|}
\hline \multirow{5}{*}{ N145a } & Nakamura, Alexandre Yudy \\
\hline & $\begin{array}{l}\text { Avaliação radiográfica comparativa da reabsorção radicular apical após o } \\
\text { tratamento com o aparelho de Fränkel e os Guias de Erupção / Alexandre Yudy } \\
\text { Nakamura. -- Bauru, } 2004 \text {. }\end{array}$ \\
\hline & 122p. : il. ; $30 \mathrm{~cm}$. \\
\hline & Universidade de São Paulo. \\
\hline & Orientador: Prof. Dr. Guilherme Janson \\
\hline
\end{tabular}

\footnotetext{
Autorizo, exclusivamente para fins acadêmicos e científicos, a reprodução total ou parcial desta dissertação, por processos fotocopiadores e outros meios eletrônicos.

Bauru, 6 de dezembro de 2004.

Assinatura:
}

Projeto de pesquisa aprovado pelo Comitê de Ética em Pesquisa da Faculdade de Odontologia de Bauru, Universidade de São Paulo, em 09 de agosto de 2004. 


\section{ALEXANDRE YUDY NAKAMURA}

05 de setembro de 1978

Assis Chateaubriand - PR

$1996-2000$

$2001-2002$

$2003-2004$

Associação
Nascimento

Curso de Odontologia pela Faculdade de Odontologia de Bauru - Universidade de São Paulo

Curso de Aperfeiçoamento em Ortodontia pela ACOPEN Assessoria e Consultoria em Ortodontia, Pesquisa e Ensino

Curso de Pós-graduação em Ortodontia, ao nível de mestrado, pela Faculdade de Odontologia de Bauru Universidade de São Paulo APCD - Associação Paulista de Cirurgiões-Dentistas APEO - Associação Paulista de Especialistas em Ortodontia 
“(...) penso que é melhor sentir-se herdeiro do que se sentir dono de algo que se transmite. Não sei se tenho alguma coisa. Mas sei que recebi muito".

Jorge Luis Borges 


\section{DEDICATÓRIA}

Com amor, respeito e gratidão, dedico este trabalho a

Maria Terezinha Natsue Nakamura

e

Kokite Nakamura,

minha mãe e meu pai. 


\section{AGRADECIMENTO ESPECIAL}

Prof. Dr. Guilherme Janson

Coordenador do Curso de Pós-Graduação em Ortodontia, ao nível de mestrado, e orientador deste trabalho. O convívio permitiu-nos conhecer suas faculdades científicas, seu indiscutível dinamismo e o apreço pelo estudo. Como professor de elevados princípios, recebe de seus alunos mais do que a admiração, a amizade. 


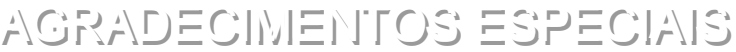

Ao Prof. Dr. Marcos Roberto de Freitas, Chefe do Departamento de Odontopediatria, Ortodontia e Saúde Coletiva.

Ao Prof. Dr. José Fernando Castanha Henriques, Prefeito do Campus administrativo da Faculdade de Odontologia de Bauru - Universidade de São Paulo.

Ao Prof. Dr. Guilherme Janson, Coordenador do Curso de Pós-Graduação em Ortodontia, ao nível de Mestrado.

Aos professores da disciplina de Ortodontia, do Departamento de Odontopediatria, Ortodontia e Saúde Coletiva, Professores Doutores Arnaldo Pinzan, Décio Rodrigues Martins e Renato Rodrigues de Almeida.

Homens com qualidades por todos reconhecidos. Suas participações em nossa formação sempre serão lembradas. 


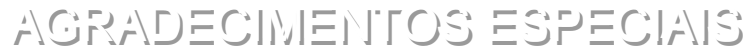

Aos queridos irmãos Ricardo, Tatiana e Bianca. Valiosos presentes da vida. $O$ destino nos aproximou e a amizade nos uniu. Pela cumplicidade em todos os momentos.

Aos tios Albertina e Hermínio, pelo carinho e bondade demonstrados.

Aos tios Isaura e Elizeo, presentes nos momentos mais importantes.

As primas Carolina e Mirian, exemplos de alegria e de afeição.

A toda família, tios, tias e primos, por acompanhar o nosso trajeto com interesse e motivação, e pelos encontros cheios de boas recordações.

Aos amigos William e Marcelo, pela convivência e pelo exemplo de companheirismo.

Aos colegas de infância Sayuri, Hideki, Katsuo, Yoko e Yudi, que concederam, de maneira generosa e lealmente, as suas amizades. 


\section{AGRADECIMENTOS}

Aos colegas do curso de mestrado, Adriana, Darwin, Fernando Pedrin, Fernando Torres, Kelly, Lívia, Marcos, Marcus, Paula, Rafael, Renata e Sérgio, por todos os momentos que convivemos e por tudo que aprendemos.

Aos colegas do curso de doutorado, Analu, Célia, Fabrício, Fenanda, José Eduardo, Karina Freitas, Karina Lima, Leniana, Rejane, Ricardo e Rodrigo, pela amizade e cordialidade despendidas.

Aos colegas do antigo curso de doutorado, Adriano, Ana Carla, Ana Cláudia, Daniela, Danilo, Karina, Karyna, Fausto, Paulo e Renata, pela solicitude e atenção concedidas.

Aos colegas de mestrado das outras disciplinas, pelo convívio memorável da "Prática Docente".

$\mathrm{Na}$ vida acadêmica nos aprimoramos com alegrias e tristezas entre aqueles que por aqui passaram e que retornaram aos seus locais de origem, e que compõem os grupos pelos quais sucessiva e periodicamente formamos enquanto vivemos. É uma troca de favores e gentilezas pelos quais Deus é o maior responsável e que, em última análise, deve merecer o nosso mais profundo reconhecimento, pela sua infinita bondade. 


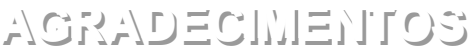

Aos Professores Doutores Maria Fidela de Lima Navarro e José Carlos Pereira, Diretora e Presidente da Comissão de Pós-Graduação da Faculdade de Odontologia de Bauru, da Universidade de São Paulo.

Ao Prof. Dr. José Fernando Castanha Henriques, Prefeito do Campus administrativo da Faculdade de Odontologia de Bauru, da Universidade de São Paulo.

Aos professores da Faculdade de Odontologia de Bauru - USP, pela formação acadêmica sólida oferecida durante o curso.

Ao Prof. Dr. José Roberto Lauris, pela atenção e dedicada orientação na análise estatística deste trabalho e pela paciência na sua realização.

Aos funcionários da disciplina de Ortodontia, Cristina, Vera, Neide, Sérgio, Daniel, Danilo, Thiago e Régis, pela disponibilidade e agradável convivência durante o curso.

Aos funcionários da Acopen, Sônia, Luciana, César e Valter, por toda a consideração e respeito demonstrados.

Aos funcionários da Biblioteca, pela cordialidade e atenção demonstradas.

Aos atenciosos e gentis funcionários da secretaria de pós-graduação.

Aos pacientes, indispensáveis à nossa formação profissional e humana.

Uma instituição, qualquer que seja ela, é moldada por leis e normas, mas cumpre suas funções por meio de homens. Quanto melhor for o caráter deles e mais sólidas a sua formação, tanto mais saudável e eficiente será a instituição. 


\section{SUMÁRIO}

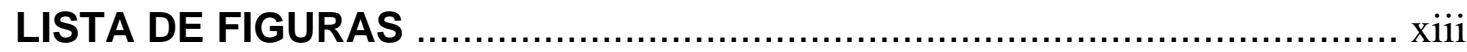

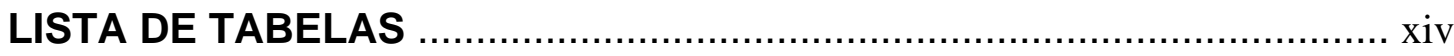

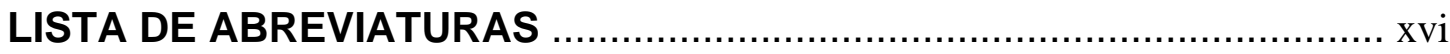

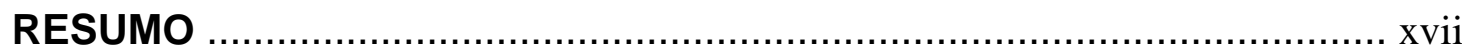

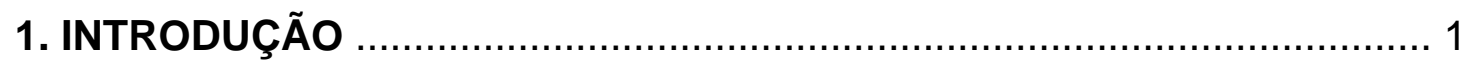

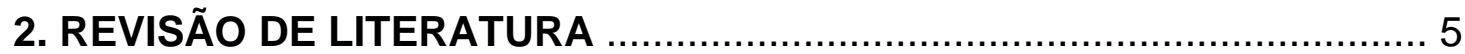

$2.1 \mathrm{O}$ aparelho de Fränkel ......................................................... 6

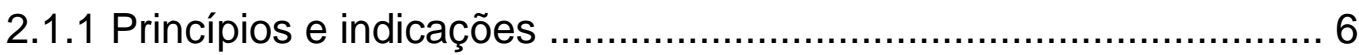

2.1.2 Efeitos sobre as estruturas dentoesqueléticas ......................... 9

$2.2 \mathrm{O}$ aparelho Guia de Erupção ...................................................... 17

2.2.1 Histórico e indicações ....................................................... 17

2.2.2 Efeitos sobre as estruturas dentoesqueléticas ........................ 19

2.3 Os aparelhos removíveis e a reabsorção radicular ......................... 23

2.4 Movimento ortodôntico em dentes com rizogênese incompleta .......... 30

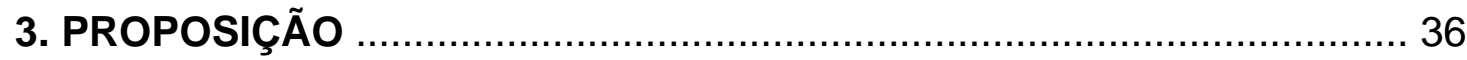

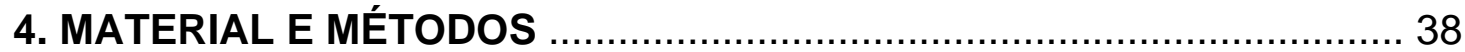

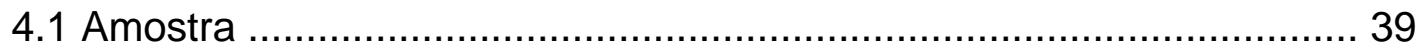

4.1.1 Grupo experimental 1 .............................................. 39

4.1.2 Grupo experimental 2 ...................................................... 41

4.1.3 Grupo controle .......................................................... 43

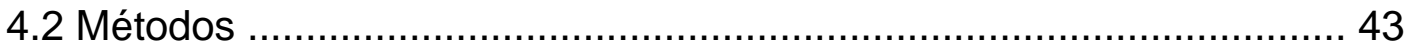

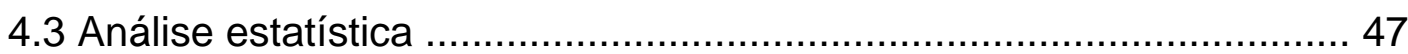

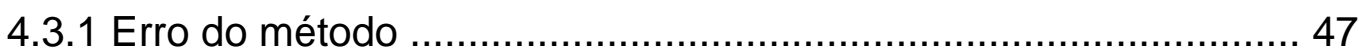

4.3.2 Comparações entre os grupos ............................................... 48

4.3.3 Prevalência de reabsorção nos incisivos ................................. 50

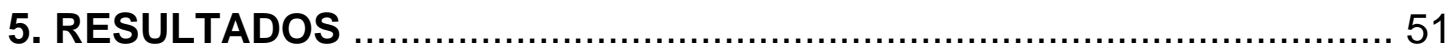




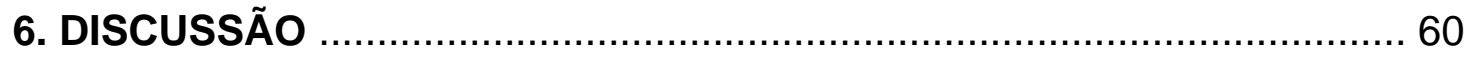

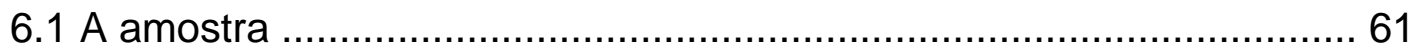

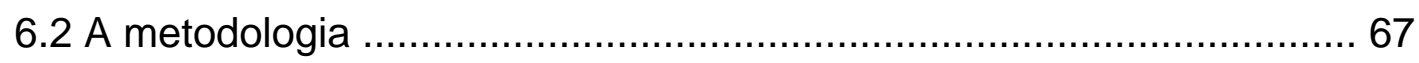

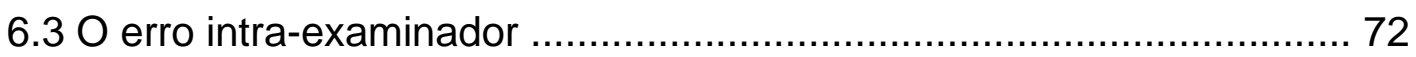

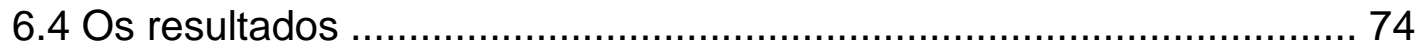

6.4.1 Quantidade de reabsorção ............................................ 74

6.4.2 Prevalência de reabsorção ............................................... 84

6.5 Implicações clínicas ........................................................ 88

6.6 Sugestões para pesquisas futuras ............................................. 89

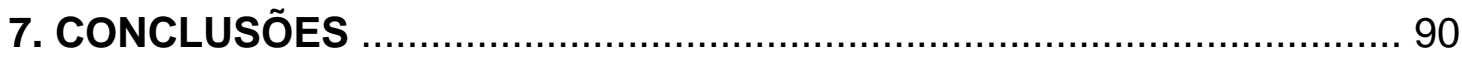

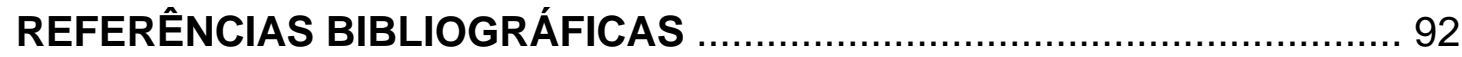

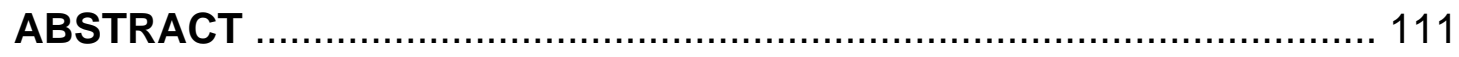

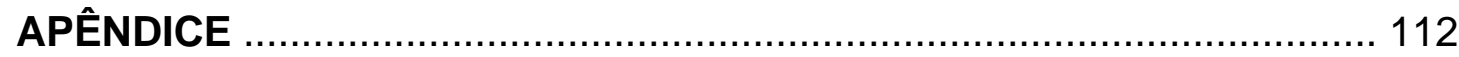




\section{LISTA DE FIGURAS}

Figura 1 - Aparelho de Fränkel 43

Figura 2 - Aparelho Guia de Erupção 43

Figura 3 - Classificação dos graus de reabsorção, segundo Levander \& Malmgren

Figura 4 - Radiografias periapicais dos incisivos superiores 46

Figura 5 - Radiografias periapicais dos incisivos inferiores 46 


\section{LISTA DE TABELAS}

Tabela 1 - Resultados do erro intra-examinador 53

Tabela 2 - Comparação entre as idades iniciais e finais, pelo teste $t$ de Student

Tabela 3 - Comparação entre os tempos de tratamentos, pelo teste $t$ de Student

Tabela 4 - Comparação entre as idades no momento da tomada radiográfica, pela análise de variância - ANOVA

Tabela 5 - Compatibilidade dos grupos entre os gêneros, pelo teste Quiquadrado

Tabela 6 - Comparação do grau de reabsorção entre os três grupos, pelo teste Kruskal-Wallis

Tabela 7 - Comparação do grau de reabsorção entre os subgrupos 1.1, 2.1 e o grupo controle, pelo teste Kruskal-Wallis

Tabela 8 - Comparação do grau de reabsorção entre os subgrupos 1.2, 2.2 e o grupo controle, pelo teste Kruskal-Wallis

Tabela 9 - Comparação do grau de reabsorção entre o subgrupo 1.1 e o subgrupo 1.2, pelo teste Mann-Whitney

Tabela 10 - Comparação do grau de reabsorção entre o subgrupo 2.1 e o subgrupo 2.2, pelo teste Mann-Whitney 56

Tabela 11 - Comparação do grau de reabsorção entre os três grupos, sem discriminação pelo tipo de dente, por meio do teste Kruskal-Wallis 
Tabela 12 - Comparação do grau de reabsorção entre os subgrupos 1.1, 2.1 e o grupo controle, sem discriminação pelo tipo de dente, por meio do teste Kruskal-Wallis

Tabela 13 - Comparação do grau de reabsorção entre os subgrupos 1.2, 2.2 e o grupo controle, sem discriminação pelo tipo de dente, por meio do teste Kruskal-Wallis 57

Tabela 14 - Comparação do grau de reabsorção entre o subgrupo 1.1 e o subgrupo 1.2, pelo teste Mann-Whitney 57

Tabela 15 - Comparação do grau de reabsorção entre o subgrupo 2.1 e o subgrupo 2.2, pelo teste Mann-Whitney 57

Tabela 16 - Prevalência de reabsorção radicular nos três grupos estudados, de grau leve a moderado (escores 1 e 2) 58

Tabela 17 - Prevalência de reabsorção radicular nos três grupos estudados, de grau acentuado (escore 3) 58

Tabela 18 - Prevalência de reabsorção radicular nos subgrupos 1.1, $1.2,2.1$ e 2.2, de grau leve a moderado (escores 1 e 2) 59

Tabela 19 - Prevalência de reabsorção radicular nos subgrupos 1.1, 1.2, 2.1 e 2.2, de grau acentuado (escore 3) 59 


\section{LISTA DE ABREVIATURAS}

D12 - Incisivo lateral superior direito

D11 - Incisivo central superior direito

D21 - Incisivo central superior esquerdo

D22 - Incisivo lateral superior esquerdo

D42 - Incisivo lateral inferior direito

D41 - Incisivo central inferior direito

D31 - Incisivo central inferior esquerdo

D32 - Incisivo lateral inferior esquerdo

DM - Média dos escores obtidos das avaliações dos incisivos 


\section{RESUMO}

O objetivo deste estudo foi avaliar comparativamente a quantidade de reabsorção radicular apical dos tratamentos realizados com dois tipos diferentes de aparelhos removíveis: o Regulador de Função de Fränkel e os Guias de Erupção, em relação a um grupo de indivíduos não-tratados. Foram obtidas radiografias periapicais após o término do tratamento, pela técnica do paralelismo, dos incisivos superiores e inferiores de 88 pacientes, divididos em três grupos. O grupo 1 compreendeu 24 pacientes tratados com o aparelho de Fränkel, o grupo 2 incluiu 40 pacientes tratados com o aparelho Guia de Erupção e o grupo 3 constou de 24 indivíduos que não receberam tratamento ortodôntico. Como critério de avaliação, utilizou-se a classificação da reabsorção de acordo com o método proposto por Levander \& Malmgren. A calibração intra-examinador foi considerada substancial ou quase perfeita pela avaliação Kappa. Os resultados do teste Kruskal-Wallis demonstraram diferença estatisticamente significante dos grupos e subgrupos de pacientes tratados em relação ao grupo controle. Entretanto, não se verificou diferença estatística entre o aparelho de Fränkel e o Guia de Erupção. Na comparação entre os subgrupos tratados somente com aparelhos removíveis e aqueles que finalizaram o tratamento com aparelho fixo, o teste Mann-Whitney indicou diferença estatisticamente significante. Considerando a prevalência da amostra total de pacientes tratados, não se encontrou reabsorção radicular em 23,25\% dos dentes analisados. O grupo 2 apresentou maior prevalência de reabsorção de grau leve a moderado, e o grupo 1 apresentou reabsorção de grau acentuado somente em 7,30\% dos dentes analisados, correspondente a dois pacientes. A prevalência de reabsorção para cada grupo de incisivos indicou, em ordem decrescente, maior reabsorção para os incisivos centrais superiores, seguidos dos incisivos laterais superiores, incisivos centrais inferiores e, por último, os incisivos laterais inferiores. 
INTRODUÇÃO 


\section{INTRODUÇÃO}

Na Ortodontia, assim como na Medicina, o objetivo maior do plano de tratamento incide no desenvolvimento de uma estratégia que beneficie ao máximo o paciente com um mínimo de riscos e custos. O completo entendimento das vantagens e desvantagens que um procedimento oferece pode auxiliar o profissional na busca por melhores resultados com os tratamentos.

Durante a década de 80, mais de 130 artigos reportando dados sobre grupos de 10 ou mais pacientes com más oclusões de Classe II foram publicados nas quatro revistas ortodônticas mais divulgadas de língua inglesa $^{139}$. Reunidos, esses artigos oferecem informações de 14 sistemas de aparelhos diferentes ou protocolos de tratamento. Embora os objetivos sejam os mesmos, isto é, melhorar a estética facial e dentária, conservar ou melhorar a saúde bucal, e desenvolver uma oclusão estável e funcional, as formas de tratamento são bastante diferentes.

Apesar da grande variedade, os aparelhos funcionais são similares entre si quanto ao seu modo de ação. De maneira geral, todos os aparelhos funcionais utilizados para corrigir as más oclusões de Classe II apresentam um componente que promove uma alteração postural na mandíbula, posicionandoa anteriormente ${ }^{57}$. Entretanto, os aparelhos funcionais removíveis apresentam ampla diversidade em seus desenhos, que poderia afetar diretamente na sua aceitação pelos pacientes. O aparelho ideal deveria ser confortável para o paciente, permitir os movimentos mandibulares, deixar espaço para a língua, além de oferecer resultados satisfatórios para as estruturas dentoalveolares e esqueléticas $^{49}$. Dentre os dispositivos mais aceitos entre os ortodontistas, destaca-se o Regulador de Função de Fränkel ${ }^{40}$, proposto em 1966, com um mecanismo de ação que considera o exercício muscular como um importante fator no desenvolvimento ósseo ${ }^{15}$. O Regulador de Função diferencia-se dos outros aparelhos funcionais por ser mucosuportado. Por meio de escudos de acrílico colocados ao nível dos vestíbulos bucal e labial, altera a posição mandibular enquanto mantém um mínimo de contato com os dentes inferiores, teoricamente propiciando um menor efeito dentoalveolar ${ }^{44,138}$. 
BERGERSEN, em 1975, em trabalho citado por POURRAHIMI ${ }^{110}$, desenvolveu um aparelho pré-fabricado, de material borrachóide, para a correção das más oclusões, denominado de Guia de Erupção. Como um dispositivo pré-fabricado, suas características consistem, basicamente, da associação de um aparelho funcional com um posicionador ${ }^{11-14}$. As características atribuídas aos aparelhos funcionais consistem do avanço mandibular para a correção da má oclusão de Classe II, e a abertura vertical na região anterior para permitir maior desenvolvimento vertical dos dentes posteriores. Dos posicionadores, o Guia de Erupção herdou a possibilidade de pequenos movimentos dentários devido ao material elastomérico do qual é constituído. Como propiciam maior detalhamento oclusal ao final do tratamento, estudo prévio já demonstrou que a porcentagem de pacientes com os Guias de Erupção que necessitaram de aparelhos fixos foi menor em comparação com o aparelho de Fränkel ${ }^{65}$. Não obstante o Regulador de Função e o Guia de Erupção apresentem mecanismos de ação similares, o tamanho reduzido do aparelho contemporâneo idealizado por Bergersen causa menos desconforto e por isso facilita a utilização por pacientes jovens. Associado a este fator, a necessidade de menor número de horas diárias de uso do aparelho já mostrou resultar em maior colaboração do paciente, em relação ao Regulador de Função, que deve ser usado em tempo integral, excetuando apenas o período das refeições ${ }^{65}$.

Durante a escolha por uma das modalidades de tratamento mencionadas, o primeiro aspecto a se considerar é a sua eficácia na correção dos diversos aspectos da má oclusão, especialmente as características oclusais. Quando pesquisada, esta não se apresentou como um fator diferencial, ambos os aparelhos demonstrando alterações semelhantes ${ }^{59}$. Conseqüentemente, torna-se necessária uma avaliação comparativa do aparelho Guia de Erupção com o Regulador de Função de Fränkel sobre outros ângulos, para que se possa compreender melhor as vantagens e desvantagens advindas do uso de cada aparelho, adquirindo assim, fundamentos que auxiliem na escolha de um ou de outro dispositivo, na prática clínica. Uma forma de contribuir para o melhor entendimento da ação desses aparelhos seria a determinação da quantidade de reabsorção radicular, conseqüência 
deletéria e inevitável a qualquer intervenção ortodôntica. Como o aparelho de Fränkel não aplica forças verticais nos incisivos e nem corrige apinhamentos, além de alterar a posição mandibular por atuação na face lingual do processo alveolar inferior, poderia se conjeturar menor quantidade de reabsorção radicular. Dessa forma, comparar-se-ão dois tipos distintos de aparelhos removíveis quanto à forma de atuação sobre os dentes: um preconizado a atuar principalmente na musculatura peribucal, sem apoio nos incisivos, em que se espera um menor efeito dentoalveolar e, conseqüentemente, menor grau de reabsorção radicular; e o outro amparado diretamente sobre os incisivos para alterar a posição da mandíbula no sentido horizontal, e também com efeitos sobre o trespasse vertical. Foi com este objetivo em mente que se decidiu dar prosseguimento às primeiras investigações ${ }^{59,65}$, avaliando agora, seus efeitos sobre as estruturas radiculares, por meio de comparação com um grupo de jovens que não receberam tratamento ortodôntico. 
REVISÃO DE LITERATURA 


\section{REVISÃO DE LITERATURA}

Este tópico propõe-se a revisar a literatura pertinente à terapêutica com os aparelhos ortopédicos removíveis (Fränkel e o Guia de Erupção), apresentando suas características e protocolos de tratamentos, e os seus efeitos dentoesqueléticos em jovens durante a fase de crescimento e desenvolvimento craniofacial. Em adição, discorrer-se-ão sobre a reabsorção radicular ocasionada pela utilização dos aparelhos removíveis e os efeitos da movimentação ortodôntica em dentes com rizogênese incompleta. Os aparelhos supracitados destacam-se pelos bons resultados obtidos e são os preconizados pela disciplina de Ortodontia da Faculdade de Odontologia de Bauru na correção das más oclusões de Classe II que respondem favoravelmente a esses aparelhos.

\subsection{0 aparelho de Fränkel}

\subsubsection{Princípios e indicações}

A utilização dos aparelhos ortopédicos funcionais data desde a década de 1930, porém somente a partir do início da década de 1970 que estes aparelhos tornaram-se muito utilizados na correção de discrepâncias sagitais moderadas ou severas da mandíbula, em jovens ${ }^{15}$.

A palavra ortopedia provém do grego que significa "educação ou correção apropriada" ${ }^{44}$. O princípio da ortopedia bucofacial é o de otimizar o desenvolvimento das estruturas bucofaciais, removendo as restrições ou retardamentos na complementação dos padrões de crescimento, eliminando as alterações funcionais que possam interferir na evolução normal do desenvolvimento dentoesquelético. De outro modo, o termo aparelho ortopédico funcional refere-se aos aparelhos removíveis que utilizam as forças musculares provenientes da alteração intermitente da posição postural da mandíbula, com a finalidade de corrigir as más oclusões ${ }^{49}$.

O objetivo da ortodontia tradicional, seja com aparelhos fixos ou 
removíveis, é uma mudança de forma, esperando que ao final do tratamento haja uma adaptação espontânea do comportamento neuromuscular. Em contraste, o princípio de ação da ortopedia funcional objetiva corrigir a falha de desempenho postural e as alterações espaciais. A correção de um padrão morfológico anormal será o resultado natural de uma adaptação da forma aberrante à função alterada.

Dentre os aparelhos ortopédicos funcionais, destaca-se o Corretor Funcional, denominado em seguida como "Regulador de Função" (RF), idealizado por FRÄNKEL ${ }^{41}$ e FRÄNKEL \& FRÄNKEL ${ }^{44}$, na Alemanha, em 1967. Como o próprio termo Regulador de Função sugere, o tratamento utilizando este aparelho, primariamente, não é dirigido aos dentes ou aos próprios tecidos ósseos, mas, principalmente às alterações funcionais associadas à má formação dentoesquelética. Indicado principalmente para a correção da Classe II, durante a dentadura mista ou permanente precoce, sua concepção baseiase nos princípios da ortopedia médica, que considera o exercício e o treinamento dos músculos como fatores importantes no desenvolvimento dos ossos $^{44}$.

MOYERS ${ }^{96}$ considera que na Classe II, divisão 1 , o perfil retrognata e a sobressaliência dentária excessiva exigem que os músculos faciais e a língua se adaptem mediante padrões anormais de contração. Tipicamente, há uma hiperatividade do músculo mentoniano, que se contrai fortemente para elevar o orbicular dos lábios para efetuar o selamento bucal. Porém, FRÄNKEL \& FRÄNKEL ${ }^{44}$ não concordam com a que denomina de "apreciação morfológica", que atribui a dificuldade de selamento bucal aos desvios estruturais. Estes autores e seus seguidores afirmam que a Classe II é o resultado de um comportamento postural deficiente da musculatura, derivado de ou superimposto a uma tendência genética.

Ao restabelecer as condições espaciais fisiológicas da cavidade bucal, corrigindo as alterações estruturais existentes, por meio do Regulador de Função, ocorre a normalização do desempenho funcional dos músculos formadores da cápsula peribucal, pelo treinamento da musculatura. Esta passa ser forçada a adaptar sua performance funcional às superfícies externas dos escudos de acrílico, que podem ser consideradas como a configuração correta 
do processo dentoalveolar, normalizando o padrão de comportamento muscular. FRÄNKEL \& FRÄNKEL ${ }^{44}$ advogam que um aparelho que altere a posição da mandíbula pela estimulação proprioceptiva, em vez de fazê-lo pelo travamento posicional dos dentes, possui maior efeito sobre o desenvolvimento mandibular ${ }^{23}$. Tanto é assim que, para a correção da Classe II, LEE ${ }^{76}$ recomenda a utilização do RF somente nos casos graves onde exista uma contribuição identificável dos tecidos moles na discrepância dentoesquelética.

Dessa forma, segundo seu idealizador ${ }^{41}$, este aparelho atua exercitando a musculatura bucofacial, modificando o padrão postural dos músculos, basicamente por meio de escudos de acrílico, unidos por fios ortodônticos, dispostos nos vestíbulos dos dentes anteriores e posteriores. Durante o tratamento, deve-se enfatizar a importância do selamento labial adequado como um importante componente da terapia funcional. O paciente deve exercitar a respiração nasal com os lábios em contato, dessa forma eliminando a atividade muscular anormal. Os exercícios labiais devem iniciar desde o primeiro dia de uso do dispositivo ${ }^{89}$. O propósito dos exercícios é encorajar a respiração nasal, fortalecer o músculo orbicular dos lábios, e diminuir a atividade do músculo mentoniano.

Para a correta indicação do Regulador de Função deve-se considerar que este aparelho não é um dispositivo de movimentação dentária e nem está destinado a atuar diretamente sobre os tecidos esqueléticos, mas sim sobre o conjunto peribucal de tecidos moles. O aparelho de Fränkel diferencia-se da maioria dos outros aparelhos ortopédicos funcionais porque altera a posição mandibular enquanto mantém um contato mínimo entre os dentes e o aparelho, teoricamente propiciando um menor efeito dentoalveolar. Por isto, sua aplicação é limitada e em muitas ocasiões deve ser utilizado em conjunto com aparelhos fixos ou removíveis. A mecanoterapia fixa pode ser aplicada para a finalização do caso, ou inclusive antes do uso do RF, corrigindo as más posições dentárias e/ou discrepâncias dentoalveolares, de modo que o RF seja utilizado mais como um aparelho de contenção, que ao regularizar a função muscular, evita a recidiva do tratamento com aparelho fixo ${ }^{44,102,138}$. Esta fase é muitas vezes utilizada para intruir os incisivos inferiores e para vestibularizar os incisivos superiores, previamente ao uso do Regulador de Função. Segundo 
MCNAMARA Jr.; HOWE; DISCHINGER ${ }^{92}$, a intrusão dos incisivos inferiores reduz a quantidade de abertura vertical conseqüente ao registro de mordida anterior do aparelho de Fränkel. Em casos de curva de Spee profunda, um menor desenvolvimento vertical da AFAI poderá ser observada se os incisivos tiverem sido intruídos. A intrusão dos incisivos previamente ao tratamento com o Fränkel presumivelmente teria como resultado uma posição mais anterior do mento, ao final do tratamento.

\subsubsection{Efeitos sobre as estruturas dentoesqueléticas}

Apesar de classificado primariamente como mucosuportado, existem alguns componentes do RF que, obviamente, apresentam efeitos mecânicos. Desta forma, quando os fios tocam os dentes, exercem pressão e podem produzir efeito de movimentação dentária. Cuidado especial com o aparelho de Fränkel deve ser tomado para que o apoio de caninos permaneça em contato com a face mesial do primeiro pré-molar, que é de grande importância para assegurar a ancoragem intermaxilar. Da mesma forma que é impossível alterar a posição de um dente sem o uso de ancoragem, o RF é incapaz de alterar a posição mandibular sem que o aparelho seja estabilizado contra os dentes superiores.

Em entrevista, McNAMARA Jr. ${ }^{89}$, em 1982, relatou que quando comparou 58 pacientes com Classe II, tratados com o aparelho de Fränkel a um grupo de pacientes não tratados, notou um pequeno efeito de restrição do crescimento da maxila no grupo experimental. O efeito do tratamento com 0 dispositivo sobre o crescimento da mandíbula foi maior do que sobre o crescimento da maxila. Em média, o comprimento efetivo da mandíbula aumentou 3,5mm por ano no grupo tratado, comparado ao aumento de 2,3mm por ano no grupo sem tratamento.

Para determinar se a correção da má oclusão com o aparelho de Fränkel era ocasionada pelas alterações na relação das bases ósseas, pelas alterações nas posições dentárias ou pela combinação de ambos, ROBERTSON ${ }^{118}$, em 1983, comparou dois grupos de 12 jovens. O grupo 1 consistiu de jovens apresentando má oclusão de Classe II, divisão 1 com idade 
média inicial de 11 anos e final de 13,1 anos. O grupo 2 compôs-se de jovens apresentando má oclusão de Classe III, com idade inicial de 9,4 anos e final de 11,4 anos. Após o período inicial de adaptação, os pacientes deviam usar o aparelho de 20 a 24 horas por dia. Notou que as alterações produzidas pelo aparelho de Fränkel foram principalmente dentoalveolares. No grupo com má oclusão de Classe II ocorreu redução dos trespasses horizontal e vertical. A redução do trespasse horizontal foi resultado da inclinação para lingual dos incisivos superiores e para vestibular dos incisivos inferiores. As alterações esqueléticas foram mínimas.

MCNAMARA Jr.; BOOKSTEIN; SHAUGHNESSY ${ }^{91}$, em 1985, estudaram cefalometricamente uma amostra de 100 pacientes com má oclusão de Classe II, tratados com o aparelho de Fränkel durante 24 meses e compararam-na com um grupo controle semelhante de 41 jovens sem tratamento. Verificaram que o principal efeito do aparelho resultou no aumento do comprimento mandibular e das dimensões verticais da face. O aparelho não apresentou efeito sobre as estruturas esqueléticas da maxila. Os efeitos no posicionamento do ponto A refletem apenas as alterações do tratamento sobre as estruturas dentárias. Observaram uma diminuição da movimentação mesial dos molares superiores, no sentido horizontal, mas não no sentido vertical. Ocorreu inclinação para lingual dos incisivos superiores e para vestibular dos incisivos inferiores, assim como uma maior erupção dos molares inferiores, que não mostraram avanço horizontal em relação ao corpo mandibular, mas que avançaram substancialmente em relação à maxila.

A influência do tratamento com o RF em 25 pacientes que apresentavam má oclusão de Classe II foram avaliadas consecutivamente por meio de sobreposições cefalométricas por HAMILTON; SINCLAIR; HAMILTON ${ }^{50}$, em 1987, e também foram realizadas tomografias para se avaliar a posição do côndilo. Após 24 meses de tratamento os autores notaram que o aparelho de Fränkel corrigiu a má oclusão primariamente por alterações dentárias, com poucas modificações esqueléticas ou de posição do côndilo. Não se observou restrição no crescimento anterior da maxila como também não se notou estimulação do crescimento mandibular. Houve um pequeno aumento no ângulo do plano mandibular e aumento da altura facial ântero-inferior durante o 
tratamento. O aparelho de Fränkel produziu significante inclinação para lingual dos incisivos superiores e para vestibular dos incisivos inferiores.

MCNAMARA Jr; HOWE; DISCHINGER ${ }^{92}$, em 1990, compararam cefalometricamente dois tipos de aparelhos funcionais indicados para 0 tratamento da má oclusão de Classe II: o Regulador de Função de Fränkel RF2, aparelho primariamente mucosuportado, e o Herbst, aparelho apoiado diretamente sobre os dentes, em relação a um grupo controle. Para o grupo do Fränkel, 41 pacientes tratados em clínica particular ${ }^{91}$ foram avaliados, com idade média de 11 anos e 6 meses no início do tratamento. O grupo tratado com o aparelho de Herbst consistiu de 45 pacientes, com idade de 12 anos ao início do tratamento. Para compatibilizar as idades iniciais, considerou-se o intervalo entre 10 anos e seis meses e 13 anos e um mês. Segundo os autores, o propósito desse critério de exclusão se deve ao fato de que, em geral, a terapia com o Fränkel se inicia em idade mais precoce do que o tratamento com o Herbst. Como resultados, verificaram que ambos as formas de tratamento produziram mudanças esqueléticas e dentoalveolares similares no complexo craniofacial. Obviamente os efeitos do uso dos aparelhos não foram uniformemente distribuídos, com diferenças em áreas específicas, dependendo do dispositivo utilizado. Com relação às alterações dentoalveolares, os incisivos superiores movimentaram-se para lingual 0,1 mm/ano para o grupo do Fränkel, e 0,5mm/ano para o grupo do Herbst. Os incisivos inferiores experimentaram um movimento de vestibularização de $2 \mathrm{~mm}$ maior para o grupo tratado com o aparelho de Herbst. A explicação para os autores seria o mecanismo diferente de atuação entre os dois aparelhos, sendo que se devem esperar maiores alterações dentoalveolares com o Herbst, aparelho suportado pelos dentes, em relação ao Fränkel. Em conclusão, salientaram que a avaliação considerou somente medições esqueléticas e dentárias observadas cefalometricamente, e outros fatores deveriam também ser considerados na seleção por um tipo de aparelho funcional.

Comparando as alterações cefalométricas em pacientes com Classe II, divisão 1, tratados com os aparelhos extrabucal cervical, Fränkel e Herbst, URSI $^{142}$, em 1993, propôs verificar os efeitos destes aparelhos sobre o complexo craniofacial. A amostra constituiu-se de telerradiografias de 30 
pacientes tratados com o aparelho extrabucal, 35 com o Regulador de Função e 29 com o aparelho de Herbst, com idades iniciais entre 9 e 12 anos. Para tanto, selecionou um grupo controle composto por 29 jovens não tratados e com más oclusões similares. Os resultados permitiram observar um crescimento mandibular significantemente maior nos grupos tratados com os aparelhos ortopédicos funcionais, simultaneamente a um aumento no grau de protrusão mandibular, comparando-se com o grupo tratado com o aparelho extrabucal cervical e o grupo controle. O padrão de crescimento craniofacial não foi influenciado em nenhum grupo tratado. Notou também um incremento das alturas faciais anterior e posterior significantes nos três grupos experimentais, concentrado principalmente nos terços inferiores dos pacientes tratados com o Regulador de Função e o aparelho de Herbst. Verificando os componentes dentoalveolares, observou uma significante retrusão dos incisivos superiores nos jovens tratados com os aparelhos extrabucal cervical e Fränkel, enquanto as posições horizontal e vertical dos molares superiores demonstraram uma maior influência do aparelho de Herbst. Os incisivos inferiores apresentaram uma discreta tendência a linguoversão com o aparelho extrabucal; no grupo tratado com o Fränkel esta tendência foi de intensidade similar, mas em sentido contrário.

Havendo a necessidade de se realizar um estudo prospectivo ${ }^{91}$ com o aparelho de Fränkel, TORUÑO ${ }^{138}$ em 1995 avaliou as alterações cefalométricas dos componentes craniofaciais e dentários, em jovens brasileiros, leucodermas com Classe II, divisões 1 e 2, após um ano de tratamento. A amostra constituiu-se de 27 jovens, com idade variando entre $9 \mathrm{e}$ 10 anos, sendo que 23 apresentavam Classe II, divisão 1 e os outros quatro possuíam Classe II, divisão 2. Para tanto, utilizou telerradiografias em norma lateral, obtidas no início e ao final de tratamento. Os resultados demonstraram que o referido aparelho promoveu um aumento do comprimento mandibular e da altura facial ântero-inferior, assim com a linguoversão dos incisivos superiores. Evidenciou-se também uma suave restrição da protrusão maxilar e do deslocamento anterior dos molares superiores; um discreto aumento da protrusão mandibular e da inclinação para vestibular dos incisivos inferiores foi observado. Verificou os mesmos efeitos em relação ao tratamento da Classe II, 
divisão 2, diferindo unicamente pela vestibularização dos incisivos superiores.

COURTNEY; HARKNESS; HERBISON ${ }^{34}$, em 1996, em estudo prospectivo, avaliaram as alterações maxilares e na base do crânio em 13 pacientes tratados com o RF e 12 com o ativador de Harvold, e as compararam com um grupo controle de 17 jovens. Ambos os aparelhos demonstraram aumentos estatisticamente significantes na altura facial total e ântero-inferior, sendo um pouco maior no grupo tratado com o ativador de Harvold. Entretanto, os efeitos do tratamento se confinaram principalmente nas estruturas dentoalveolares. A redução do trespasse horizontal ocorreu pela lingualização dos incisivos superiores e vestibularização dos incisivos inferiores, maior para o grupo tratado com o ativador.

No mesmo ano, utilizando os mesmos grupos do estudo anterior, WEBSTER; HARKNESS; HERBISON ${ }^{145}$ verificaram a associação das alterações cefalométricas ocorridas durante o tratamento com ambos os aparelhos e o índice PAR (Peer Assesment Rating), utilizado para medir as alterações oclusais pela avaliação das características dos modelos de estudo. Objetivaram relacionar principalmente a tendência de crescimento do paciente com o sucesso do tratamento ortodôntico, especialmente no sentido anteroposterior. Em comparação com o grupo controle, os grupos tratados, conjuntamente, mostraram as seguintes alterações significantes: aumento do comprimento mandibular, inclinação inferior da maxila e da mandíbula, aumento das alturas faciais total, posterior e ântero-inferior, redução dos trespasses vertical e horizontal e maior erupção do primeiro molar permanente inferior. O índice PAR mostrou associações positivas com o aumento das alturas faciais posterior e total, a retrusão maxilar, aumento do ângulo SNB e diminuição do ANB. Uma correlação negativa ocorreu com a inclinação inferior da maxila e da mandíbula e o aumento da AFAI. Interessantemente, o aumento do comprimento mandibular não mostrou correlação com a avaliação do sucesso do tratamento. Os autores verificaram que a premissa de que um "bom" crescimento da mandíbula ${ }^{134}$ contribui para o sucesso dos resultados do tratamento apresenta dúvidas. Asseveraram ainda que as alterações no ponto B ocorreram em função da inclinação para vestibular dos incisivos inferiores. 
$\mathrm{Na}$ pesquisa realizada por GHAFARI et al. ${ }^{46}$ no ano de 1998, compararam-se os efeitos do aparelho extrabucal com o aparelho de Fränkel, em pacientes que apresentavam Classe II, divisão 1. Dividiram os pacientes de cada grupo pela idade esquelética e pela magnitude do ângulo ANB (com o mínimo de 4,50). Selecionou-se 63 pacientes com idades entre 7 e 13 anos. Os resultados foram avaliados utilizando modelos e telerradiografias em norma lateral. Nos modelos, ambos os grupos mostraram uma melhora nas relações de canino e molar, com melhor resultado para o grupo com o AEB. No arco superior, o grupo que utilizou o AEB mostrou um maior aumento da distância intercaninos enquanto o grupo que utilizou o RF apresentou um maior aumento da distância intermolares. No arco inferior, os aumentos destas distâncias foram maiores para o grupo com o RF. Verificaram que o aparelho extrabucal distalizou os molares superiores e restringiu o desenvolvimento para anterior da maxila. O aparelho de Fränkel promoveu uma menor restrição para anterior da maxila e uma maior verticalização dos incisivos superiores. Comparando-se os resultados em relação à posição mandibular, verificaram que o aparelho de Fränkel apresentou melhores resultados quando comparado ao aparelho extrabucal. Observaram também uma maior vestibularização dos incisivos inferiores no grupo tratado com o aparelho RF. Entretanto, não se observou uma diferença significante no comprimento mandibular entre os aparelhos estudados. Ademais, os pacientes que utilizaram o aparelho de Fränkel obtiveram uma maior redução na quantidade do trespasse horizontal, em função de uma força no sentido distal atuante sobre os incisivos superiores.

WOODSIDE ${ }^{147}$, em 1998 considerou que a correção da Classe II pelos aparelhos ortopédicos funcionais pode ocorrer pela combinação dos seguintes fatores: alterações dentoalveolares; restrição do crescimento anterior da face média; estímulo do crescimento mandibular além do que ocorreria normalmente num jovem em crescimento; redirecionamento do crescimento condilar de uma direção ântero-superior para uma direção posterior; deflexão do formato do ramo; expressão horizontal do crescimento mandibular de ântero-inferior para horizontal; alterações na anatomia e função neuromuscular induzindo à remodelação óssea; e alterações adaptativas na localização da fossa glenóide para uma posição mais anterior e vertical. 


\section{BISHARA \& ZIAJA ${ }^{15}$, CREEKMORE \& RADNEY ${ }^{35}$ e RIGHELLIS ${ }^{117}$} concordam que a correção da Classe II é obtida por meio de uma combinação de efeitos dentoalveolares, em torno de 60 a 70\% do total das alterações, e ortopédicos, que variam de 30 a 40\%, propiciando o retardamento ou redirecionamento do crescimento mesial e vertical da maxila; o aumento do comprimento mandibular; o retardamento do crescimento dentoalveolar mesial e vertical da maxila; o crescimento mesial e vertical dentoalveolar inferior; a correção do trespasse horizontal acentuado pela combinação de efeitos ortopédicos maxilares e mandibulares, com uma inclinação para palatino dos incisivos superiores e para labial dos incisivos inferiores e a remodelação da ATM.

Em estudo recente, JANSON et al. ${ }^{58}$ avaliaram prospectivamente e cefalometricamente os efeitos do RF em 18 jovens brasileiros após dois anos de tratamento, pelos alunos de pós-graduação da disciplina de Ortodontia, da Faculdade de Odontologia de Bauru. Os resultados demonstraram que o RF originou um aumento estatisticamente significante no comprimento do corpo mandibular, do tamanho proporcional da mandíbula em relação ao tamanho da maxila e da altura facial ântero-inferior. Induziu também, uma maior protrusão dos incisivos inferiores, assim como um maior desenvolvimento vertical dos molares inferiores. Observou-se também uma redução da sobremordida, sobressaliência e da protrusão e inclinação dos incisivos superiores. Entretanto não se observaram alterações no padrão de crescimento dos pacientes, ou melhora esquelética das bases ósseas. Concluiu-se, portanto, que os efeitos do RF-Ic para as correções das más oclusões foram principalmente dentoalveolares, com uma menor participação das alterações esqueléticas.

Para a correção da má oclusão de Classe III a ação do Regulador de Função de Fränkel ocasiona uma movimentação dos dentes superiores para frente e um redirecionamento do crescimento mandibular no sentido vertical, com respostas variáveis na maxila ${ }^{91}$. O RFIII proporciona um aumento do trespasse horizontal positivo devido a uma somatória da rotação para baixo e para trás da mandíbula, com conseqüente diminuição do ângulo SNB e aumento do ANB. O aumento do ângulo SNA e da protrusão dos incisivos superiores não são significantes. A sobremordida diminui devido principalmente 
à rotação para baixo e para trás da mandíbula ${ }^{62,141}$.

Com o objetivo de alcançar os melhores resultados com o tratamento, o profissional deve atentar a alguns detalhes durante a manipulação do aparelho. Segundo sustentam seus defensores, a técnica de moldagem, o preparo do modelo de trabalho, a construção e manipulação clínica do aparelho, representam de importância fundamental na obtenção dos resultados clínicos desejados $^{138}$. Do paciente requer-se utilização contínua, não somente o uso noturno. Além disso, o exercício funcional diário é de vital importância para o sucesso do aparelho de Fränkel. Para FRÄNKEL ${ }^{41}$, funcional significa atividades contínuas, repetitivas e freqüentes, o que não é possível somente durante o sono ${ }^{40,43,44}$.

A participação do paciente com o tratamento é a chave do sucesso para a ortopedia funcional com o uso do $\mathrm{RF}^{65}$. A colaboração do paciente pode ser avaliada principalmente com a verificação da melhora da correção da má oclusão, o acúmulo de cálculo na superfície do aparelho e a abertura de diastemas devido ao assentamento do fio estabilizador do aparelho. Um sinal clínico é freqüentemente observado pelo profissional mais experiente: o não relato por parte dos pais ou pelo paciente de desconforto e ausência de evidências de áreas hiperêmicas dos tecidos moles da boca demonstra falta de colaboração $^{91}$. A cooperação do paciente é extremamente necessária e deve ser encorajada pelos pais, considerando o tamanho do aparelho e a necessidade de utilizá-lo constantemente.

O tratamento ativo na fase da dentadura mista dura entre 1,5 a 2 anos, seguido por um período de contenção de 2 anos. A época para o início de tratamento com o aparelho de Fränkel inclui duas faixas etárias: a idade mais jovem compreende as crianças no primeiro período transitório e período intertransitório, e a idade mais tardia inclui os indivíduos no segundo período transitório e início da dentadura permanente. Para alcançar os melhores efeitos terapêuticos a época ótima compreende o período de crescimento rápido, ou tão logo os incisivos laterais inferiores entrarem em oclusão ${ }^{44}$. Ao postergar o tratamento para uma idade mais avançada, por volta da puberdade, o profissional poderá não obter boa cooperação do paciente, fundamental para o 
sucesso do tratamento. Além disso, no período final da dentadura mista, os molares e os caninos decíduos apresentam o processo de rizólise em estágio avançado ou já foram esfoliados, o que dificulta o correto apoio do aparelho. Iniciando até o período intertransitório, o término do tratamento coincidirá com o início da dentadura permanente, quando então poderá ser instalado o aparelho fixo, que não pode ser removido pelo paciente ${ }^{65}$.

O aparelho de Fränkel apresenta limitações especialmente em problemas de apinhamento que requerem controle individual dos dentes. Todavia, modificações sagitais e verticais significativas podem ser obtidas. Somente uma pequena porcentagem dos casos pode ser tratada com 0 aparelho de Fränkel isoladamente. Os aparelhos fixos são quase sempre utilizados após a fase de tratamento com o aparelho de Fränkel ${ }^{89}$. Freqüentemente indica-se, ao menos em 50\% dos casos tratados com estes aparelhos, a necessidade de aparelhos fixos para a correção e melhora dos detalhes finais ${ }^{65}$.

\subsection{O aparelho Guia de Erupção}

\subsubsection{Histórico e indicações}

Os Guias de Erupção são considerados como uma associação do posicionador dentário com os aparelhos funcionais, que atua sob a ação da musculatura. Após sofrer adaptação por KESLING ${ }^{68}$, em 1944, o posicionador passou a objetivar a finalização e contenção após o tratamento ortodôntico convencional. No ano seguinte, em 1945, o autor ${ }^{69}$ descreveu o posicionador dentário para a utilização no posicionamento artístico e na contenção dos dentes após o tratamento com aparelhos fixos ter sido completado. A partir dos modelos de gesso, os dentes eram recortados individualmente, realizava-se a montagem de trabalho ("set up") e sobre ela confeccionava-se o posicionador. Relatou que este aparelho não somente estabilizava os dentes em seus processos alveolares, mas por ser confeccionado em material borrachóide, proporcionava uma pequena movimentação dentária, permitindo o 
posicionamento artístico dos dentes. O paciente, ao colocar o posicionador forçava os dentes para dentro dos encaixes do aparelho e pela elasticidade do material, os dentes assumiam as posições programadas. A grande vantagem do posicionador sobre os aparelhos convencionais consistia na utilização das forças funcionais produzidas pela pressão dos músculos, possibilitando eficácia na intrusão dentária dos incisivos, nos casos de trespasse vertical excessivo ${ }^{69}$.

Com o objetivo de simplificar a confecção do posicionador e ampliar as suas possibilidades para o tratamento, BERGERSEN ${ }^{11-14}$, em 1967, desenvolveu o posicionador pré-fabricado e, mais tarde, baseado em princípios semelhantes, introduziu o Guia de Erupção para a correção das más oclusões $^{110}$. Além de possibilitar pequenos movimentos dentários pelo material borrachóide, os Guias de Erupção proporcionam a protrusão mandibular para a correção das discrepâncias ântero-posteriores nos casos de Classe II, simultaneamente com uma maior abertura no sentido vertical, na região anterior. Isto é conseguido pela espessura maior do material na região anterior, e pela ausência de contato dos dentes posteriores com o material. Desta maneira, o contato do material com os dentes anteriores, associado à pressão exercida pelo paciente, restringe o desenvolvimento vertical destes dentes, ao mesmo tempo em que possibilita um maior desenvolvimento vertical dos dentes posteriores. Para que o aparelho fosse pré-fabricado, os tamanhos dos dentes, as distâncias intercaninos e intermolares, assim como a altura das coroas clínicas foram determinados, baseando-se na média, mais ou menos dois desvios-padrão, obtidos em estudos da amostra de Bolton. Dessa forma, a partir das médias de tamanho dentário da população, o aparelho pode ser encontrado em 13 tamanhos, para ajustarem-se em $95 \%$ dos $\operatorname{casos}^{65}$.

Duas séries diferentes foram desenvolvidas para determinadas faixas etárias: a série $C$, para utilização na dentadura decídua e mista precoce, corrigindo os trespasses vertical e horizontal durante a erupção dos incisivos permanentes; e a série G (Occlus-o-Guide), para casos sem extração durante a dentadura mista, anteriormente à erupção dos segundos molares permanentes $^{11,12,14,65}$.

Ao relatar sobre o modo de utilização do aparelho Guia de Erupção, BERGERSEN ${ }^{11}$, em 1984, descreveu-o como uma combinação de um 
posicionador e um aparelho funcional, que atua sob a ação da musculatura. Segundo o autor, a vantagem deste aparelho consiste em sua ação semelhante a um ativador na correção das relações sagitais e verticais dos arcos dentários e na possibilidade de correção das rotações, do apinhamento e da melhora na intercuspidação dentária, como um posicionador, o que acelera o tempo de tratamento. O tempo recomendado de uso do aparelho foi de 4 horas, ativamente, durante o dia e, passivamente, à noite. As quatro horas de uso diário devem ser divididas em quatro períodos de uma hora, não consecutivas, com o paciente ocluindo intensamente no aparelho, por um minuto, relaxando por trinta segundos, repetidamente, até completar meia hora. $\mathrm{Na}$ outra meia hora deverá manter ligeira pressão no aparelho. Os lábios devem permanecer selados durante os exercícios. Resultados satisfatórios devem ser avaliados dentro de 1 a 2 meses, caso contrário deve-se, suspender o uso do aparelho. Dois fatores são importantes para o sucesso do tratamento: a seleção do caso e a motivação do paciente ${ }^{65}$.

\subsubsection{Efeitos sobre as estruturas dentoesqueléticas}

Em pesquisa clínica, BERGENSEN ${ }^{11-13}$, em 1977, utilizou o Guia de Erupção em 50 crianças que apresentavam Classe II, divisão 1 e trespasse vertical e horizontal aumentados. O aparelho foi recomendado a ser usado durante 4 horas diárias, ativamente, onde o paciente ocluía com força sobre 0 dispositivo e passivamente à noite, por 2 a 8 meses. O autor observou redução média de $69,5 \%$ do trespasse vertical e de $85 \%$ do trespasse horizontal no período de 6 meses, além de melhora na relação de Classe II.

Em 1980, YOSHII ${ }^{148}$ aperfeiçoou o posicionador de KESLING ${ }^{68,69}$, indicado para utilização apenas para pequenas movimentações dentárias ao final do tratamento com aparelhos fixos. O autor desenvolveu o "Posicionador Dinâmico" para a correção das más oclusões. Ao contrário do dispositivo original, o posicionador dinâmico é confeccionado a partir da montagem de trabalho realizada no modelo inicial do paciente, com a má oclusão. Os dentes são recortados do modelo e montados em posição de oclusão normal. 0 silicone utilizado para confecção do aparelho pode apresentar três diferentes 
consistências: silicone leve, médio e pesado. Um mesmo paciente pode utilizar vários posicionadores dinâmicos confeccionados com os vários tipos de silicone, iniciando sempre por um posicionador confeccionado com um silicone mais leve, produzindo uma força ideal para a correção e posteriormente, utilizando os silicones mais consistentes. A fase ideal para o início do tratamento é na dentadura mista tardia. Este aparelho age servindo como guia da erupção dentária durante a fase de crescimento. Indica-se a utilização do posicionador dinâmico para as más oclusões de origem dentária com leves apinhamentos, rotações, más posições dentárias individuais e trespasse vertical excessivo; para as más oclusões de Classe II e III de origem funcional e para as más oclusões de Classe II e III esqueléticas suaves. Casos com grande discrepância dente-osso, onde a extração seriada está indicada, o posicionador pode ser utilizado durante o período de extração para melhorar o posicionamento dentário, finalizando o tratamento com aparelho fixo.

POURRAHIMI ${ }^{110}$, em 1982, objetivou avaliar os efeitos dentários do Guia de Erupção, na redução dos trespasses vertical e horizontal excessivos. Para tanto, utilizou este aparelho em 36 jovens, sendo que dezessete pacientes apresentavam má oclusão de Classe I e 19 apresentavam Classe II, divisão 1. Para comparação, utilizou 20 jovens que não receberam tratamento algum, com idade média compatível. Nove apresentavam má oclusão de Classe I e 11 apresentavam Classe II, divisão 1. Ambos os grupos apresentavam trespasses vertical e horizontal similares ao início do período de observação. Os resultados demonstraram diminuição significativa dos trespasses vertical e horizontal, acompanhada de intrusão e inclinação para lingual dos incisivos superiores, extrusão e suave inclinação para vestibular dos incisivos inferiores. A altura facial ântero-inferior e o ângulo interincisivos aumentaram significantemente no grupo tratado.

Em 1990, METHENITOU et al. ${ }^{93}$ investigaram a possibilidade do aparelho Guia de Erupção limitar o desenvolvimento vertical e horizontal excessivos durante as horas de sono da criança. Para isso, analisaram telerradiografias iniciais e após 13 meses de tratamento os efeitos produzidos pelo dispositivo em 43 pacientes apresentando idade média de 6,17 anos, inicialmente. Para efeito de comparação, utilizou-se um grupo controle de 50 
jovens não tratados, do estudo longitudinal da amostra de crescimento de Denver da Universidade Odontologia do Colorado, possuindo o mesmo tipo de má oclusão do grupo avaliado. Ocorreu um aumento suave da altura facial ântero-inferior durante o tratamento. Concluíram que quando o aparelho era utilizado durante a fase da dentadura mista, os dentes permanentes ânterosuperiores não irrompiam excessivamente, o que ajudava a manter o trespasse vertical normal.

JANSON et al. ${ }^{60}$, em 1997, desenvolveram um estudo prospectivo com o objetivo de avaliar cefalometricamente os efeitos do Guia de Erupção nas bases apicais, no padrão de crescimento craniofacial, nos dentes e na altura facial anterior. O grupo experimental constou de 27 pacientes apresentando má oclusão de Classe II, divisão 1 e 3 com má oclusão de Classe I, com idade cronológica média de 9 anos, ao início do tratamento. O grupo experimental foi comparado com um grupo controle de 30 jovens, com idade similar e observado durante o mesmo período de tempo. Neste grupo, 26 jovens apresentavam uma má oclusão de Classe II, divisão 1, e 4 uma má oclusão de Classe I. As telerradiografias foram obtidas ao início do tratamento e após 10 meses. Os jovens do grupo controle pertenciam à amostra do estudo longitudinal de crescimento craniofacial da Disciplina de Ortodontia da Faculdade de Odontologia de Bauru. Os resultados deste estudo demonstraram que este tipo de tratamento aumentou significantemente a altura facial ântero-inferior, reduziu a sobremordida e a sobressaliência, restringiu o desenvolvimento vertical dos incisivos superiores e aumentou 0 desenvolvimento vertical dos molares superiores e inferiores. Não houve nenhuma mudança significante no crescimento maxilar ou mandibular, e ocorreu uma leve melhora na relação esquelética maxilomandibular.

Sendo necessária uma avaliação cefalométrica do aparelho Guia de Erupção por um tempo mais prolongado, os mesmos autores ${ }^{64}$ avaliaram, no ano de 2000, os possíveis efeitos cefalométricos do aparelho Guia de Erupção no complexo craniofacial, em uma amostra de 30 pacientes após 26 meses de tratamento, comparados a um grupo controle. Os resultados demonstraram um aumento significante do comprimento mandibular, alturas faciais inferior e total. Verificaram também, uma melhora na relação maxilomandibular, assim como 
uma melhora dos trespasses vertical e horizontal, e uma inibição do desenvolvimento vertical dos incisivos superiores. Este estudo demonstrou que os efeitos decorrentes do aparelho Guia de Erupção, são principalmente dentoalveolares, com um pequeno, mas significante efeito esquelético.

Devido às amplas modalidades de tratamento propostas para a má oclusão de Classe II, como se verifica com os dois tipos de aparelhos anteriormente mencionados, a escolha por um deles deve se basear, principalmente, sobre a sua eficácia, aliada a facilidade de aplicação pelo profissional, bem como a aceitação do método pelo paciente ${ }^{65,132}$.

Com a finalidade de conhecer as respostas dos pacientes à utilização do Regulador de Função de Fränkel e ao aparelho Guia de Erupção, JANSON et al. ${ }^{65}$, em 2003, avaliaram o grau de colaboração e aceitação desses dois tipos diferentes de aparelhos removíveis. Além disso, compararam a porcentagem de pacientes que necessitaram de aparelhos fixos para a finalização. A amostra de guia de erupção compreendeu 57 pacientes, dos quais a quantidade de 43 utilizou o aparelho Occlus-o-Guide série G e 14 pacientes, o aparelho Nite-Guide série C; a amostra de Fränkel compreendia 38 pacientes, sendo que destes, 34 apresentavam má oclusão de Classe II e 5 pacientes, má oclusão de Classe III. Verificaram uma menor quantidade de pacientes que apresentaram uma boa colaboração com o aparelho de Fränkel, devido ao aparelho apresentar maior volume e desta maneira causar maior desconforto. Também se encontrou uma maior porcentagem de pacientes com os Guias de Erupção que não necessitaram de aparelho fixo. Para os autores, esse resultado era esperado, uma vez que os Guias de Erupção apresentam as características dos posicionadores dentários, que propiciam maior detalhamento da oclusão final ${ }^{110}$.

Com o objetivo de comparar os resultados oclusais do aparelho Guia de Erupção e o aparelho de Fränkel, JANSON et al. ${ }^{59}$, em 2004, avaliaram os modelos de estudo inicial e final utilizando o índice PAR. Vinte e cinco pacientes compreenderam o grupo submetido ao tratamento com o aparelho de Fränkel e 30 pacientes foram tratados com o aparelho Guia de Erupção. Os 
autores concluíram que as alterações oclusais foram semelhantes para os dois grupos investigados. Esse estudo demonstrou que a escolha dentre esses dois aparelhos não deve se basear exclusivamente em sua eficácia, e sim em outras características. A principal desvantagem do aparelho de Fränkel é o desconforto inicial que o paciente pode apresentar, por se tratar de um dispositivo volumoso ${ }^{128}$. Já o aparelho Guia de Erupção apresenta a vantagem de ser menor e por isso mais confortável. Entretanto, o seu tempo de tratamento se apresenta suavemente maior. Como oferecem o mesmo índice de sucesso terapêutico, a escolha sobre qual aparelho removível o clínico optará para o tratamento de uma má oclusão recairá sobre outros fatores que não seja a sua eficácia.

\subsection{Os aparelhos removíveis e a reabsorção radicular}

Na última década, várias revisões de literatura sobre o tema reabsorção radicular foram publicadas ${ }^{19,20,54,71,143}$. A revisão de literatura de BREZNIAK \& WASSERSTEIN ${ }^{18,17}$ lista mais de 120 artigos que reportam os diversos aspectos do problema da reabsorção dentária entre 1856 e 1993. Durante este período, obteve-se um progresso significante no entendimento do processo. Um novo termo relacionado a este fenômeno foi cunhado: a conseqüência iatrogênica do tratamento ortodôntico ${ }^{20}$.

Um interesse crescente sobre a reabsorção radicular apical inflamatória ocorreu principalmente por duas razões: o mapeamento do genoma humano, transmitindo a idéia de que isso poderia assistir num melhor entendimento do processo patológico ${ }^{4,53}$ e o número crescente de processos legais contra os ortodontistas. Do ponto de vista legal a situação torna-se embaraçosa para o profissional e, se nenhum tipo de conduta preventiva foi adotada durante 0 tratamento com a finalidade de controlar este risco, poderia ser caracterizada como negligência. Na edição de dezembro de 2002 da revista Seminars in Orthodontics, cujo tema é "Avaliação e conduta dos riscos na clínica ortodôntica", o exemplo legal mais comumente discutido foi relacionado à reabsorção radicular induzida ortodonticamente ${ }^{124}$. 
De fato, quando atinge os seus estágios mais avançados, a reabsorção radicular pode representar um risco à estabilidade e longevidade da oclusão ${ }^{67}$. Felizmente os pacientes que terminam o tratamento ortodôntico com reabsorções severas ou extremas, com implicações clínicas significantes, não caracterizam situações freqüentes $^{63}$. Em 1988, LEVANDER \& MALMGREN ${ }^{77}$ investigaram a estimação do risco de reabsorção radicular apical após o tratamento ortodôntico. O exame radiográfico foi realizado em 390 dentes, avaliados antes, após 6 a 9 meses do início, e ao final do tratamento. Após o término do tratamento, cinco dentes, correspondentes a $1 \%$ da amostra, apresentaram reabsorção extrema, com perda de mais de um terço do comprimento radicular. A maioria dos autores concorda com este trabalho na constatação de que raramente a reabsorção radicular apical decorrente do tratamento ortodôntico é extrema ${ }^{25,38,66,119}$.

A literatura pertinente oferece dados e evidências de alguns aspectos importantes relacionados ao maior ou menor grau de reabsorção radicular. Os movimentos dentários de inclinação, mecânica intrusiva, tratamento com extrações dentárias, técnicas ortodônticas que aplicam forças intensas são freqüentemente associados à reabsorção dentária ${ }^{20,95}$. Na comparação entre aparelhos fixos e removíveis, as evidências revelam um índice maior de reabsorção radicular durante o uso de aparelhos fixos ${ }^{80,103,105}$. KETCHAM $^{70}$ alegou que a função normal dos dentes é alterada pelo efeito de esplintagem dos aparelhos fixos por um longo período de tempo e pode causar reabsorção radicular. Por outro lado, STUTEVILLE ${ }^{136}$ sugeriu que os movimentos oscilatórios ("jiggling”) causados pelos aparelhos removíveis são mais prejudiciais para as raízes.

OPPENHEIM ${ }^{101}$, de 1930 a 1933, ocupou-se na interpretação histológica do movimento dentário ortodôntico, propondo que uma força excessiva aplicada intermitentemente produz um movimento de oscilação do dente, levando-o a sofrer reabsorção radicular. No entanto, em 1944, o autor ${ }^{101}$ ainda advogava o uso de forças suaves para "um movimento dentário fisiológico", e recomendava períodos freqüentes de descansos.

Em 1938, STUTEVILLE ${ }^{137}$ analisou microscopicamente os dentes de 14 jovens e de 64 cães. Os dentes foram movidos com forças ativas, por 
distâncias determinadas, com o objetivo de verificar as alterações que ocorrem nos dentes e nos tecidos de suporte, após a movimentação dentária induzida. Para o pesquisador, as estruturas mais afetadas com a movimentação foram a membrana periodontal, a superfície da raiz, o osso alveolar, a gengiva e a polpa. Analisando as lâminas obtidas, o autor encontrou reabsorção radicular praticamente em todos os casos tratados ortodonticamente, mas em maior número nos casos com aparelhos removíveis, em função dos movimentos de vai-e-vem. Salientou que outros fatores importantes devem ser analisados em relação à força aplicada, como a quantidade e o tipo de força, a distância na qual a força permanece ativa e a presença de outras forças, além daquelas exercidas pelo aparelho.

Durante aproximadamente 30 anos, o norueguês Kaare Reitan ${ }^{113}$ foi considerado um dos maiores pesquisadores sobre a microscopia da movimentação dentária induzida. No ano de 1957, estudou o emprego de forças em Ortodontia. Analisou a variação individual dos tecidos, o tipo de força aplicada e os princípios mecânicos. Os resultados permitiram elucidar a existência de um período inicial necessário após a aplicação da força, para atingir um estágio de proliferação celular e promover a alteração tecidual. Este estágio depende de uma série de fatores, incluindo a idade do paciente e as características anatômicas da raiz. Com relação ao tipo de força aplicada, distinguiu as forças do tipo intermitente e contínua. As forças intermitentes podem determinar a formação de áreas hialinas de maior extensão e de curta duração, quando comparada com as forças contínuas.

As forças são freqüentemente interrompidas com o uso de aparelhos removíveis. Cada momento de remoção do aparelho corresponde à interrupção da ação da força. É de conhecimento que o reparo das cavidades de reabsorção se inicia quando se elimina a força ortodôntica ou até mesmo apenas reduzida abaixo de um certo nível ${ }^{24,115}$. Este período de repouso propicia melhores condições para a resposta metabólica exigida pelo movimento dentário, permitindo melhor proliferação e atividade celular nos tecidos de suporte e criando condições mais favoráveis a uma nova resposta quando o aparelho for reativado ${ }^{30}$. Já está bem estabelecido que a força extraoral e os aparelhos funcionais produzem movimentação dentária sem a 
necessidade de uso 24 horas por dia. Acredita-se que os períodos de descanso restituem a circulação nos tecidos de suporte e melhoram a proliferação celular. Por outro lado, isto implica em menor eficiência do ponto de vista ortodôntico em relação aos aparelhos fixos. CUOGHI ${ }^{36}$, em 1995, ao analisar a movimentação dentária induzida em macacos da espécie Cebus apella, verificou que as forças aplicadas sem períodos de repouso proporcionaram maior quantidade de movimentação em um menor período de tempo. O autor verificou que a movimentação dentária induzida atingiu seu ponto máximo após 10 horas de força contínua dissipante e que, após um período de repouso de 5 horas, a quantidade de movimentação não se recuperou totalmente. Dessa maneira, entre as conclusões do estudo, estabeleceu que os períodos de repouso devem ser mínimos e não atingir 5 horas.

Entretanto, na literatura existem evidências de que as forças descontínuas são capazes de produzir movimentação dentária equivalente à obtida pelas forças contínuas. Em estudo com ratos, PROFFIT \& SELLERS ${ }^{111}$ demonstraram que forças intrusivas suaves aplicadas em 50\% do tempo produziram a mesma quantidade de movimento intrusivo que a força contínua. Mais experimentos são necessários para mostrar se esse efeito pode ser conseguido também em humanos.

Num sistema classificatório, os aparelhos funcionais removíveis se caracterizam por promover forças suaves e intermitentes, as categorias de força em que se encontram nos tipos de movimento que causam menor reabsorções ${ }^{115}$. Caracterizam-se por forças contínuas, interrompidas por períodos de repouso. Além dos aparelhos móveis, as forças intermitentes se associam a alguns recursos auxiliares ao tratamento com aparelhos fixos, como os elásticos intermaxilares.

Em 1981, RÖNNERMAN \& LARSSON ${ }^{119}$ examinaram radiografias periapicais dos incisivos superiores de 23 pacientes tratados com a técnica do Arco de Canto, antes, imediatamente após, três e 10 anos após o término do tratamento ativo. Os pacientes foram divididos em 4 grupos: o grupo A foi formado por 5 pacientes com má oclusão de Classe II, divisão 1, tratados com ativador; o grupo B constituiu-se de 9 pacientes, sendo 8 Classe II, divisão 1 e 
um Classe II, divisão 2, tratados com 4 extrações; o grupo C foi formado por 5 pacientes Classe II, divisão 1, tratados com extrações apenas no arco superior e, finalmente, o grupo D, por 4 pacientes com má oclusão de Classe I e com apinhamento, tratados com extrações em ambos os arcos dentários. A média de idade, ao início do tratamento, foi de 11 anos no grupo A e de 14,7 anos nos grupos B, C e D. A reabsorção foi classificada por escores, variando de 0 a 2. Os autores encontraram reabsorção radicular apical nos incisivos superiores, na extensão de 1 a 3 mm, em 39\% dos casos. Nenhuma reabsorção marcante foi observada no grupo tratado com o ativador, à semelhança dos resultados de LINGE \& LINGE $^{80}$, que encontraram baixa incidência de reabsorção radicular com a utilização de aparelhos removíveis. A maior movimentação necessária para a correção da má oclusão nos grupos B e C pode ter sido responsável pela maior quantidade de reabsorção encontrada nestes, em relação ao grupo $D$, embora este grupo também tenha sido tratado com extrações.

LINGE \& LINGE $^{81}$, em 1991, verificaram que o tratamento com o ativador não promoveu reabsorção radicular em seu estudo, demonstrando, que nestes casos, não há correlação entre o grau de "overjet" e de reabsorção radicular apical.

Para avaliar a qualidade dos tratamentos ortodônticos realizados no Departamento de Ortodontia, da Universidade de Lund, em Malmo, em um período de 10 anos, AHLGREN² ${ }^{2}$ em 1993, examinou os registros radiográficos de 480 pacientes tratados na clínica de pós-graduação. Cinqüenta por cento dos casos foram tratados com aparelhos fixos e a outra metade, com aparelhos removíveis. A reabsorção foi diagnosticada por meio de radiografias periapicais e panorâmicas e as alterações radiculares com menos de $1 \mathrm{~mm}$ não foram consideradas. A reabsorção radicular foi encontrada em praticamente todos os casos tratados com aparelhos fixos. Entretanto, a quantidade de encurtamento radicular foi pequeno, usualmente de 1 a 3mm, nunca excedendo a um terço do comprimento radicular, sendo que os incisivos superiores foram os dentes mais vulneráveis. O autor verificou a nãoocorrência de reabsorção radicular nos casos tratados com aparelhos removíveis. 
A predileção pela força ortodôntica leve e interrompida não tem comprovação absoluta. Em trabalho realizado em humanos, OWMAN-MOLL; KUROL; LUNDGREN ${ }^{105}$ compararam a força leve contínua com a força leve contínua interrompida. O material consistiu de 32 pré-molares superiores de 16 pacientes, que apresentavam apinhamento ou protrusão do arco superior, cujos planos de tratamento ortodôntico consistiram de extração dos prémolares superiores. Os dentes foram movimentados em direção vestibular com o aparelho fixo por períodos de 4 e 7 semanas, tempo relativamente curto de experimento. Os pacientes foram divididos em dois grupos: o primeiro recebeu quatro semanas de tratamento e, o outro, sete semanas. Em cada paciente foi aplicado força leve contínua de um lado e leve contínua interrompida do outro. A força leve contínua não era exatamente contínua, porque embora reajustada toda semana, mostrava sempre perda (média de 24\%). A força leve interrompida contínua, foi assim chamada porque após ser colocada com ativação e permanecer agindo durante 3 semanas, era deixada passiva por uma semana, para criar um intervalo de repouso e depois reativada. Os resultados em termos de quantidade de movimento mostraram maior eficácia para a força leve contínua e, em relação à reabsorção radicular, não houve diferenças.

De maneira semelhante, ACAR et al. ${ }^{1}$, em 1999, objetivaram comparar os efeitos sobre as raízes dentárias devido à aplicação de forças contínuas e descontínuas. A amostra consistiu de 22 primeiros pré-molares que seriam extraídos como parte do planejamento ortodôntico de oito pacientes. Uma força de inclinação de 100 gramas foi aplicada por meio de elásticos durante nove semanas. Um lado foi selecionado aleatoriamente para a aplicação da força contínua, por meio do uso do elástico 24 horas por dia, sem período de repouso. A cada 24 horas, o paciente trocava o elástico. No lado de aplicação da força descontínua, um elástico foi utilizado durante 12 horas diárias. Após este período, os pacientes removiam o elástico e somente reinstalavam uma nova liga elástica após 12 horas de repouso. Após o experimento os dentes foram extraídos e submetidos à avaliação por meio de microscopia eletrônica de varredura. O grau de reabsorção radicular foi avaliado por meio de escores. As áreas médias de reabsorção foram 11\% pela aplicação de força contínua e 
de $6 \%$ com força descontínua. A freqüência de arredondamento radicular apical foi maior nos dentes submetidos à força contínua. Os resultados deste estudo demonstraram que a aplicação de forças descontínuas resultam em menor reabsorção radicular.

Como em investigação prévia ${ }^{140}$ demonstrou-se que a efetividade na correção da Classe II em uma ou duas fases de tratamento apresenta poucas diferenças, BRIN et al. $^{22}$, em 2003, intentaram avaliar a reabsorção radicular dessas duas abordagens como forma de complementar informações em relação à época ótima para tratar os pacientes pré-adolescentes. Para isso, compararam a quantidade e freqüência de reabsorção em um grupo de 40 pacientes que se submeteram a tratamento em uma fase, com aparelho fixo, ou em duas fases de tratamento, em um grupo de 49 pacientes tratados com o aparelho extrabucal e outro formado de 40 pacientes tratados com o bionator, seguidos pelos aparelhos fixos. Os pacientes em cada grupo se encontravam similares quanto à idade, gênero e à severidade da má oclusão ao início do tratamento, com má oclusão de Classe II e sobressaliência maior que $7 \mathrm{~mm}$. As radiografias panorâmicas tomadas ao início do tratamento e as radiografias periapicais realizadas ao final do tratamento ortodôntico corretivo foram utilizadas para avaliação. A quantidade de reabsorção foi determinada por meio de escores. Os pacientes tratados em duas fases com o bionator, seguido por aparelhos fixos, tiveram menor grau de reabsorção radicular, de moderado à severo, enquanto que os pacientes tratados em uma fase, com os aparelhos fixos, demonstraram a maior quantidade de reabsorção. Já os pacientes tratados com o aparelho extrabucal apresentaram menor grau de reabsorção para a classificação suave. A quantidade de correção da sobressaliência durante a fase 2 do tratamento e duração da mesma foram estatisticamente associadas com o grau de reabsorção. Este tipo de movimento foi reduzido com o uso do extrabucal e o bionator. Segundo os autores, uma possível explicação para os resultados da pesquisa seria que os pacientes que se submeteram a tratamento com aparelhos ortopédicos necessitaram de menor correção da sobressaliência, durante a fase de aparelhos fixos. 


\subsection{Movimento ortodôntico em dentes com rizogênese incompleta}

Apesar de a reabsorção radicular ser assunto extensamente analisado, a literatura se apresenta escassa no tocante aos efeitos do tratamento ortodôntico em dentes com rizogênese incompleta.

O primeiro artigo que relacionou a quantidade de reabsorção radicular durante o tratamento ortodôntico com a idade foi publicado em 1936 por RUDOLPH ${ }^{121}$. Verificou que o maior número de casos de reabsorção ocorreu nos pacientes tratados durante e após os 11 anos de idade. O autor relata que, embora os dados da pesquisa não estejam disponíveis, parece evidente que a aplicação de forças suaves sobre dentes com ápice incompleto tem pouco efeito sobre o seu tamanho predestinado. De modo contrário, afirmam que os dentes podem ter o seu desenvolvimento alterado com a aplicação de forças intensas.

Em 1940, o mesmo autor ${ }^{122}$ desenvolveu um estudo radiográfico em que variáveis como gênero, idade ao início do tratamento, e o tempo de tratamento foi considerado. Os resultados mostraram que a porcentagem de reabsorção ao início do tratamento aumentou de acordo com a idade do paciente e o tempo. Dessa forma, o autor concluiu que o tratamento ortodôntico é menos prejudicial às estruturas radiculares quando iniciado precocemente. Entretanto, os resultados da pesquisa devem ser analisados cuidadosamente quanto à precisão de sua metodologia: a avaliação foi realizada por meio de radiografias panorâmicas, e não houve descrição do tipo de aparelho ortodôntico empregado e os dentes envolvidos.

Em 1972, ROSENBERG ${ }^{120}$ avaliou a prevalência e quantidade de reabsorção radicular e dilaceração ocasionadas pelo tratamento ortodôntico em dentes com rizogênese incompleta. Por meio de radiografias panorâmicas ao início e ao final do tratamento com a técnica de Begg, envolvendo as extrações de quatro pré-molares, determinou-se um valor médio de reabsorção insignificante, menor que 0,5 mm, para cada uma dos grupos de dentes estudados. Observou-se dilaceração da porção apical anterior ao tratamento em $25 \%$ dos dentes estudados. Apenas $8 \%$ dos dentes que apresentaram dilaceração após o tratamento não apresentavam antes do mesmo. Pode-se 
afirmar que estes 8\% foram ocasionados pelo tratamento. Apenas 6\% dos dentes apresentaram reabsorção maior que $2 \mathrm{~mm}$, enquanto que a prevalência de reabsorção foi de 37\%. A prevalência e a quantidade de reabsorção encontradas neste estudo não foi significantemente diferente da quantidade observada em estudos com dentes com raízes completas. Os autores constataram que os dentes com rizogênese incompleta submetidos à movimentação ortodôntica atingem o seu tamanho normal e o comprimento esperado. Não se observaram efeitos adversos e significantes que contraindiquem a movimentação ortodôntica em dentes com rizogênese incompleta. $\mathrm{Na}$ verdade, parece haver menos reabsorções radiculares nestes dentes do que nos dentes com raízes completamente formadas.

Em 1983, LINGE \& LINGE $^{80}$ avaliaram a extensão e a incidência da reabsorção radicular apical de 719 pacientes tratados ortodonticamente, em radiografias periapicais, obtidas com a técnica do paralelismo, de 2.451 incisivos. Da amostra total, que incluiu pacientes tratados com aparelho fixo pela técnica do Arco de Canto e aparelhos removíveis, 25\% dos pacientes fizeram uso de aparelhos removíveis em algum momento do tratamento. O encurtamento radicular foi determinado pela diferença de comprimento dos dentes nas radiografias finais e iniciais. Evidenciaram uma maior alteração no comprimento radicular com o uso dos aparelhos fixos. Os pacientes que iniciaram o tratamento aos 11 anos, época em que se supõe que os incisivos laterais tenham o seu desenvolvimento radicular completado, exibiram um encurtamento radicular médio em dobro $(0,97 \mathrm{~mm})$ com relação aos pacientes cujos tratamentos iniciaram antes dos 11 anos de idade (0,5mm). Os pacientes que iniciaram o tratamento ortodôntico precocemente (antes dos 11 anos), muito raramente mostraram sinais radiográficos de reabsorção radicular. Os resultados deste estudo sobre a influência da idade do paciente e o estágio do desenvolvimento radicular ao início do tratamento suporta os estudos radiográficos de RUDOLPH ${ }^{122}$ e ROSENBERG ${ }^{120}$ e os estudos histológicos de REITAN ${ }^{114}$, todos favorecendo o tratamento precoce mesmo quando a malformação radicular apical possa resultar da movimentação de dentes com desenvolvimento incompleto ${ }^{39}$. 
Com o objetivo de determinar a extensão da reabsorção radicular e avaliar os possíveis fatores predisponentes como gênero, idade no início do tratamento ortodôntico, estágio da formação radicular no início da terapia e a duração do tratamento nos dentes posteriores, HENDRIX et. al. ${ }^{56}$, em 1994, selecionaram 153 casos de jovens com idades entre 14 a 16 anos, submetidos ao tratamento ortodôntico com/sem extração, utilizando a técnica de edgewise. Foram analisadas radiografias panorâmicas pré e pós-tratamento, e os dentes foram divididos segundo o estágio de formação radicular ao início do tratamento: completa ou incompleta. Como resultado, verificaram que os dentes com rizogênese incompleta não atingiram seu tamanho "normal" esperado ao final do tratamento, mas ainda assim apresentavam raízes mais longas do que os dentes do grupo de pacientes que apresentavam dentes com raízes completas. O fenômeno foi explicado atribuindo-se aos dentes com raízes incompletas uma maior proteção, interrompendo o seu processo de desenvolvimento em vez de sofrerem reabsorção. Os autores recomendaram que os tratamentos ortodônticos sejam iniciados mais precocemente, quando as raízes ainda apresentam-se incompletas, como já salientado em estudos radiográficos $^{81,120,121}$ e histológicos ${ }^{114}$ anteriores.

CONSOLARO; MARTINS-ORTIZ; VELLOSO ${ }^{29}$, em 2001, realizaram uma revisão de literatura com o objetivo de esclarecer dúvidas à respeito da movimentação ortodôntica em dentes com rizogênese incompleta. Procuraram fornecer respostas com respeito à três perguntas freqüentes entre os ortodontistas: dentes com rizogênese incompleta quando movimentados apresentam maior índice e risco de reabsorção dentária? Podem apresentar raízes mais curtas? Podem ser movimentados ortodonticamente? Baseados na organização estrutural e no funcionamento dos tecidos responsáveis pela formação radicular a na literatura pertinente, os autores afirmaram que a morfofisiologia do processo de desenvolvimento radicular impede a ocorrência de processos de reabsorção radicular. Devido à papila dentária e tecidos vizinhos serem "moles", não haverá de ocorrer necrose e áreas hialinas na região apical, muito menos morte dos cementoblastos recém estabelecidos. Entretanto, a aplicação de forças intensas pode provocar o colabamento dos vasos e a isquemia da papila dentária e do folículo dentário, levando ao 
encurtamento do dente. Dessa forma, a movimentação de dentes com rizogênese incompleta deve obedecer às forças de baixa ou média intensidade, aplicadas em tempo adequado.

Com o propósito de avaliar a influência do aparelho Guia de Erupção "Occlus-o-Guide" nos incisivos superiores e inferiores, com rizogênese incompleta, QUINTELLA ${ }^{112}$, em 2001, analisou as radiografias periapicais de 23 pacientes, possuidores de más oclusões de Classe II, divisão 1, com apinhamento suave ântero-inferior e superior. Desses pacientes, 8 se submeteram à terapia corretiva num período posterior, constituindo um subgrupo. Para a análise comparativa selecionou para o grupo controle 23 pacientes leucodermas e que não foram submetidos ao tratamento ortodôntico pregresso, sem história de trauma nos incisivos, sinais radiográficos de patologias dentárias e com oclusão aceitável. Não se verificaram diferenças entre os tipos radiculares, portanto, concluiu que o tratamento durante a dentadura mista com o Guia de Erupção não acarreta alteração no processo de rizogênese. A quantidade de reabsorção radicular, embora estatisticamente significante, apresentou-se em grau mínimo, em comparação com o grupo controle. Entre os pacientes que fizeram uso dos Guias de Erupção, exclusivamente, e aqueles que finalizaram com aparelhos fixos, não houve diferença estatística.

Em 2002, MAVRAGANI et al. ${ }^{87}$ avaliaram a relação custo/benefício do tratamento ortodôntico precoce com respeito à reabsorção radicular dos quatro incisivos superiores. Uma amostra de 80 pacientes tratados com a técnica edgewise e a técnica do arco reto foi comparada com 66 indivíduos que não se submeteram a tratamento ortodôntico. Os pacientes foram tratados com extrações de dois ou quatro pré-molares, com uma idade média de 12,7 anos ao início da terapia. Os comprimentos das coroas e raízes dentárias foram medidos nas radiografias periapicais pré e pós-tratamento, estas corrigidas por um fator de distorção de imagem. A análise de regressão revelou que o comprimento radicular médio se relacionou significantemente com a idade ao início do tratamento. Quando a mesma idade foi considerada, as raízes cujos comprimentos aumentaram durante o tratamento ortodôntico não apresentaram diferenças quando comparadas aos dentes que não foram submetidos às 
forças ortodônticas. Os dentes com raízes parcialmente formadas previamente ao tratamento alcançaram um comprimento maior do que os dentes com as raízes totalmente formadas ao início da terapia. Concluíram que o tratamento ortodôntico não causa reabsorção radicular em dentes com raízes parcialmente formadas. Os autores julgaram conveniente iniciar a movimentação dos incisivos durante a dentadura mista, como uma fase de tratamento introdutória. Após a erupção dos outros dentes permanentes, uma segunda fase de tratamento se inicia. Embora possa prolongar o tempo de tratamento, essa estratégia pode oferecer benefícios estéticos ao paciente jovem, e os dentes anteriores ficam protegidos da reabsorção radicular.

Observa-se que a literatura se mostra extensa no que se refere ao tratamento com o aparelho de Fränkel e o aparelho Guia de Erupção, e os seus efeitos dentoesqueléticos e oclusais são de domínio do clínico experiente ${ }^{14,59,58,63,60,86,91,92}$. Entretanto, esses aparelhos se classificam como removíveis, e por isso a aplicação de força é intermitente, e os melhores resultados se apresentam em idade precoce, o que requer um tratamento mais prolongado, muitas vezes seguido por aparelhos fixos.

Neste sentido, como assistir os profissionais atuantes na clínica ortodôntica na escolha de um ou outro aparelho? Ou ainda: existe algum aparelho de preferência que promova menor efeito iatrogênico? Dessa forma, o estudo das dificuldades do tratamento ofereceria uma oportunidade de se obter perspectivas em direção à melhora na qualidade de serviços prestada aos pacientes. Por serem utilizados na fase de dentadura mista e início da permanente, durante a formação radicular dos dentes, torna-se preocupante a interferência que esses aparelhos possa ocasionar nessas estruturas. Passa a ser interessante a avaliação dos efeitos desses aparelhos sobre a estrutura radicular dos incisivos.

A procura constante dos ortodontistas por uma técnica que minimize esse efeito deletério induziram a busca pelo esclarecimento das conseqüências reais e o estabelecimento de um maior domínio na utilização de cada aparelho, aumentando a previsibilidade de seus resultados ${ }^{9,26,63,86}$. LINGE \& LINGE $^{80}$, em 
1983, escreveu: "na escolha por um tipo de tratamento, o risco de reabsorção radicular deve ser relevado juntamente à eficiência do aparelho e os objetivos de tratamento individuais". 
PROPOSIÇÃO 


\section{PROPOSIÇÃO}

O objetivo da presente investigação consistiu em avaliar comparativamente a quantidade de reabsorção radicular apical, decorrente do tratamento com o Regulador Funcional de Fränkel e o aparelho Guia de Erupção, em relação a um grupo controle. 
MATERI AL E MÉTODOS 


\section{MATERIAL E MÉTODOS}

\subsection{Amostra}

O presente estudo constituiu-se de três grupos: grupo experimental 1, grupo experimental 2 e grupo controle.

Para estudar o grau de reabsorção radicular dos pacientes com 0 tratamento utilizando o Aparelho de Fränkel e os Guias de Erupção foram selecionadas radiografias periapicais de pacientes que realizaram seu tratamento com estes aparelhos na disciplina de Ortodontia da Faculdade de Odontologia de Bauru - USP. Utilizou-se como critério básico para a seleção da amostra, que os indivíduos dos grupos 1, 2 e 3 não deveriam apresentar história pregressa de trauma, indícios de patologias dentárias, ou mesmo terem se submetido a qualquer tipo de tratamento ortodôntico, previamente à utilização destes aparelhos. A possível reabsorção estabelecida ao início do tratamento foi verificada pela análise das radiografias periapical ou panorâmica.

\subsubsection{Grupo experimental 1}

Para a composição do grupo submetido ao tratamento com o aparelho de Fränkel selecionou-se 24 pacientes (10 do gênero feminino e 14 do gênero masculino), com uma faixa etária média de 9,69 anos (DP: $\pm 1,29$, Mín.: 6,31, Máx:: 12,00) ao início do tratamento (Figura 1). O tempo total médio de tratamento ortodôntico foi de 3,59 anos (DP: $\pm 1,22$, Mín.: 1,93, Máx:: 7,30; Tabela 3). Quando da finalização dos casos, estes pacientes apresentavam uma média de idade de 13,57 anos (DP: $\pm 1,77$, Mín.: 9,92, Máx.: 17,68). Os pacientes selecionados não possuíam agenesias ou perdas de dentes permanentes, e o arco inferior apresentava apinhamento suave.

Neste grupo, na fase pré-tratamento, a maioria dos pacientes apresentava má oclusão de Classe II, divisão 1 de Angle. Três pacientes portavam má oclusão de Classe III e dois, má oclusão de Classe II, divisão 2. Todos os casos incluídos foram satisfatoriamente tratados quanto à correção da discrepância ântero-posterior. 
Em metade desses pacientes selecionados instalou-se aparelho fixo, com o propósito de refinamento da oclusão, para alinhar e nivelar os dentes anteriores, reduzir diastemas e corrigir giroversões. O tempo médio de tratamento ortodôntico fixo foi de 1,67 anos (DP: $\pm 0,91$, Mín.: 0,67, Máx.: 4,10; Tabela 3).

Realizaram-se as tomadas radiográficas periapicais imediatamente ao final do tratamento em oito pacientes. Nos 16 pacientes restantes, consideraram-se as radiografias periapicais do período pós-contenção. As radiografias periapicais foram tomadas após 3,39 anos (DP: $\pm 3,18$, Mín.: 0,00, Máx.: 8,91), em média, do final do tratamento. À época, os pacientes apresentavam idade média de 16,97 anos (DP: \3,58, Mín.: 11,72, Máx.: $22,78)$.

\section{Modo de uso do aparelho}

O tratamento com o Regulador de Função iniciou-se com o uso durante duas horas no período diurno nas duas primeiras semanas ${ }^{44}$. Para promover a estabilidade ântero-posterior do aparelho, foram efetuados desgastes nas superfícies distais dos segundos molares decíduos superiores, nas superfícies mesiais dos primeiros molares decíduos superiores e nas distais dos caninos decíduos superiores, para a adaptação dos fios do arco palatino e do apoio de caninos, respectivamente ${ }^{44,90}$. Embora deva ser usado em tempo integral, excetuando apenas o período das refeições, o tratamento iniciou-se devagar e com muito cuidado, para que o tecido mole, mucosa e musculatura se adaptassem aos poucos ao aparelho. Na primeira consulta de retorno, os tecidos moles foram examinados cuidadosamente e executaram-se os ajustes periféricos necessários e polimento. O uso de um gargarejo adstringente, água morna salina, Orabase ou Cankaid serviu como paliativo para irritações menores $^{65}$. O tempo de utilização do aparelho foi sendo aumentado paulatinamente, efetuando-se os ajustes e desgastes necessários para 0 conforto do paciente. Durante as 3 semanas seguintes, o uso foi estendido de 4 a 6 horas. Na terceira consulta, após a verificação da estabilidade, o tempo diurno foi dobrado nesta etapa. Após a completa adaptação do aparelho, 
recomendou-se aos pacientes a utilização do aparelho para dormir, sem exceção, e o máximo possível durante o dia, tirando-o apenas durante as refeições e a higienização, e na prática de esportes. Recomendou-se também aos pacientes a manter o selamento labial e praticar a leitura em voz alta com o aparelho na boca. De maneira geral, despendeu-se 2 meses antes do uso do aparelho à noite. Verificou-se o aparelho e o progresso do tratamento em intervalos de 4 semanas. Após 3 meses de uso já foi possível observar uma melhora transversal, sagital e vertical ${ }^{65}$.

Efetuou-se um avanço mandibular inicial de 5 a $7 \mathrm{~mm}$, procedendo posteriormente a um segundo avanço naqueles casos com trespasse horizontal acentuado, seguindo os critérios propostos por McNAMARA Jr90.

\subsubsection{Grupo experimental 2}

O grupo submetido ao tratamento com os Guias de Erupção consistiu de 40 pacientes (22 do gênero feminino e 18 do gênero masculino), com uma faixa etária média de 8,17 anos (DP: ^1,37, Mín.: 5,84, Máx.: 11,05) ao início do tratamento (Figura 2). O tempo total médio de tratamento foi de 4,51 anos (DP: 土2,14, Mín.: 0,84, Máx.: 7,72; Tabela 3). Quando da finalização dos casos, estes pacientes apresentavam uma média de idade de 13,01 anos (DP: $\pm 2,48$, Mín.: 9,01, Máx.: 19,13), e de 16,97 anos (DP: $\pm 2,56$, Mín.: 13,08, Máx.: 21,58) no momento da tomada radiográfica, 3,95 anos (DP: $\pm 2,91$, Mín.: 0,00, Máx.: $9,76)$ após o término do tratamento. Em sete pacientes a tomada radiográfica foi realizada ao final do tratamento, enquanto que o restante do grupo, no período pós-contenção.

Os pacientes tratados com os Guias de Erupção apresentavam as seguintes características ao início do tratamento: leucodermas, com más oclusões de Classe II, divisão 1, com apinhamento suave ântero-inferior e superior; ausência de história pregressa de trauma, ou indícios de patologias dentárias. Doze pacientes, após o período de contenção ativa, foram submetidos a nivelamento e alinhamento dos dentes, com aparelho fixo. $\mathrm{O}$ tratamento ortodôntico corretivo teve duração média de 1,68 anos (DP: $\pm 1,08$, Mín.: 0,55, Máx.: 3,83; Tabela 3). 
- Modo de uso do aparelho

Os pacientes foram instruídos para utilizar o aparelho Guia de Erupção 4 horas ativamente durante o dia e passivamente à noite. As quatro horas de utilização diária foram divididas em quatro períodos de uma hora, não consecutivas, com o paciente ocluindo intensamente no aparelho, por um minuto, relaxando por trinta segundos, repetidamente, até completar meia hora. $\mathrm{Na}$ outra meia hora, mantinha ligeira pressão no aparelho. Durante os exercícios, os lábios deviam permanecer selados ${ }^{11,12}$. Como forma de verificar o grau de cooperação ao tratamento, o material do qual é constituído o aparelho se caracteriza de forma distinta. Os Guias de Erupção apresentam um detector de cooperação para auxiliar na avaliação do profissional quanto à freqüência de uso do aparelho, que altera a cor inicial translúcida, transformando-a em uma cor quase branca opaco devido à absorção da umidade do meio bucal. Entretanto, caso em 24 horas, o paciente deixe de utilizá-lo, o aspecto brilhante volta novamente pela perda do líquido absorvido. Esta característica do aparelho pode auxiliar na observação da cooperação do paciente durante o período de tratamento ${ }^{11,12,108}$. Adicionalmente, cada paciente mantinha um cartão, que apresentava uma tabela semanal na qual deveria ser anotado o número exato de horas de utilização do aparelho, que era controlado rigorosamente a cada consulta e observado diariamente pelos pais dos mesmos.

Nos casos de pacientes colaboradores, que utilizaram o aparelho corretamente, algumas mudanças puderam ser observadas em um a dois meses, ocorrendo uma correção satisfatória com o progresso do tratamento ${ }^{65}$.

- Ortodontia corretiva

Após a obtenção de uma relação ântero-posterior normal, doze pacientes do grupo 1 e doze pacientes do grupo 2 foram submetidos ao tratamento ortodôntico corretivo para o alinhamento e nivelamento dos dentes, visando a uma boa intercuspidação. De um modo geral, utilizaram-se 
braquetes "edgewise" padrão sem especificações. Após a finalização do tratamento, instalou-se a placa de Hawley no arco superior e realizou-se a colagem do $3 \times 3$ fixo no arco inferior.

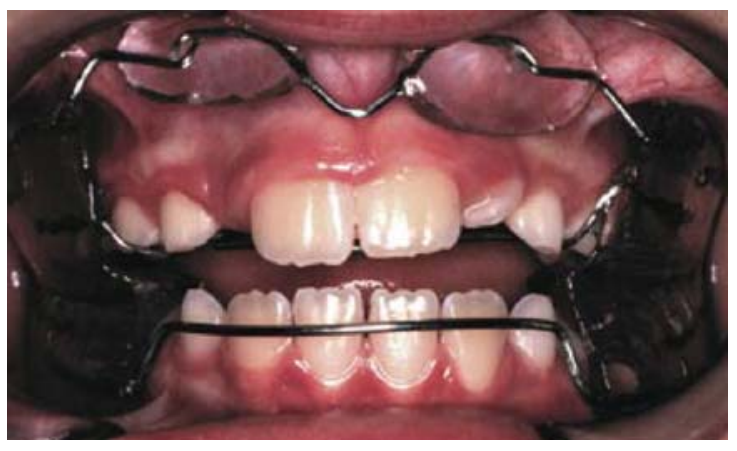

Figura 1 - Aparelho de Fränkel

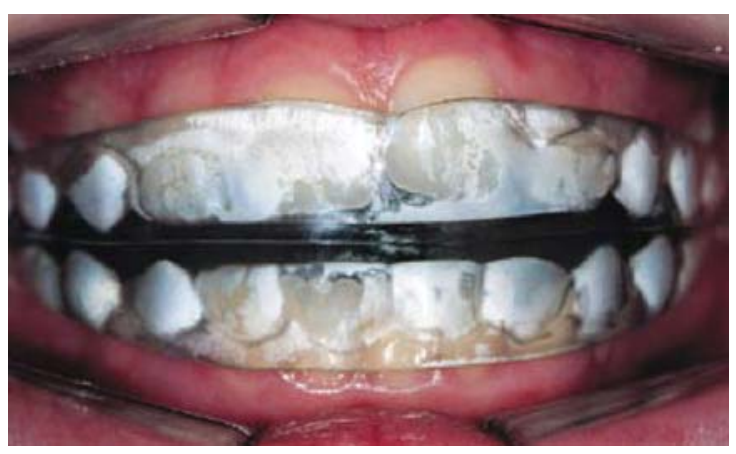

Figura 2 - Aparelho Guia de Erupção

\subsubsection{Grupo controle}

Com o intuito de diferenciar as alterações radiculares dos dois grupos experimentais em relação a indivíduos não tratados, foram selecionados para o grupo controle, 24 pacientes (12 do gênero feminino e 12 do gênero masculino), com uma faixa etária média de 17 anos (DP: $\pm 3,16$, Mín.: 13,00, Máx.: 26,07) na época da tomada radiográfica periapical. Todos os pacientes selecionados para este grupo apresentavam más oclusões de Classe II de Angle, com apinhamento suave, não tratadas ortodonticamente, servindo como parâmetro de comparação. Os pacientes não deveriam ter história pregressa de trauma nos incisivos, hábito de onicofagia ${ }^{100}$, outros vícios ${ }^{80,135}$ ou sinais radiográficos de patologias dentárias.

\subsection{Métodos}

Para a quantificação da reabsorção, foram examinadas apenas as radiografias periapicais pós-tratamento dos incisivos superiores e inferiores. Um total de 704 dentes foi analisado. Optou-se por trabalhar somente com os incisivos, por serem os dentes sujeitos à maior movimentação durante o tratamento, e porque a grande maioria dos autores concorda que são esses os 
dentes reabsorvidos com maior freqüência e intensidade durante o tratamento ortodôntico 2,3,6,25,32,51,55,63,66,70,97,109.

A documentação ortodôntica dos pacientes foi utilizada para determinar o gênero, a idade do paciente ao início do tratamento, o tipo de tratamento ao qual o paciente foi submetido (somente aparelho removível ou com associação ao aparelho fixo), o tipo de dispositivo utilizado e a duração do mesmo. O tratamento foi considerado iniciado no momento da instalação do aparelho removível e finalizado quando o seu uso foi suspenso, incluindo-se o período de contenção ativa, necessário para a manutenção das alterações desejadas. O tempo total de utilização do próprio aparelho removível como contenção dependeu da gravidade das alterações funcionais associadas ao mau desenvolvimento dento-esquelético existente antes do tratamento ${ }^{44}$. Em geral, neste período o número de horas de uso diário foi sendo diminuído gradativamente, e passou a atuar como contenção noturna por pelo menos um ano ${ }^{65}$.

As radiografias periapicais pós-tratamento foram obtidas de pacientes tratados na Clínica de Pós-Graduação da Faculdade de Odontologia de Bauru, obtidas com um aparelho de raios-X DABI 70 Spectro $1070 \mathrm{X}$, regulado para $70 \mathrm{KV}$ e $10 \mathrm{~mA}$, em um tempo de exposição de 0.75 segundos. Sempre que possível procurou-se obter o máximo de padronização para a análise radiográfica. A técnica para obtenção destas radiografias foi sempre a mesma ${ }^{5}$, utilizando-se do localizador longo para as periapicais, com uma distância anódio/filme de $40 \mathrm{~cm}$. Os filmes utilizados foram da marca Kodak "EctaSpeed" $E P 21$ e os ângulos, determinados pelo uso de um posicionador intra-oral $X C P^{a}$. A possível distorção entre as radiografias não ofereceu dificuldades, já que a quantidade de reabsorção foi expressa pelo método de escores.

Para a mensuração das radiografias, optou-se por um método de leitura digital indireto. As radiografias periapicais foram escaneadas por um Scanner ScanMaker // $S P^{\mathrm{b}}$, configurado com 300 dots per inch (dpi) de resolução, e 256 tons de cinza. As imagens foram ajustadas e analisadas no programa Adobe-

\footnotetext{
${ }^{a}$ Rinn-Dentisply.

${ }^{\mathrm{b}}$ Microtek International, Inc., Taiwan.
} 
Photoshop 7.0 . Estas imagens digitais foram armazenadas em arquivos de formato joint photographic experts group (JPEG), e puderam ser ampliadas em até $300 \%$, sem que sofressem perda em sua qualidade, em um monitor de 17" com 0.25 dot pitch fineness. Com a finalidade de melhor visualização das estruturas, a sala permaneceu totalmente escura durante as leituras e, quando necessário, o brilho e o contraste das imagens foram ajustados.

Para a quantificação da reabsorção radicular apical, a exemplo de outros pesquisadores ${ }^{9,21,22,26,52}$, utilizou-se o método proposto por LEVANDER \& MALMGREN $^{77}$, classificando a reabsorção em 5 graus (Figura 3, 4 e 5):

- grau 0: ausência de reabsorção radicular;

- grau 1: reabsorção leve, observando-se apenas contorno irregular, com a raiz apresentando o seu comprimento normal;

- grau 2: reabsorção moderada, com pequena perda radicular e o ápice exibindo um contorno quase retilíneo;

- grau 3: reabsorção acentuada, com grande perda radicular, atingindo quase 1/3 do seu comprimento;

- grau 4: reabsorção extrema, com perda de mais de 1/3 do comprimento radicular.

\footnotetext{
${ }^{c}$ Adobe Systems Incorporated 1990-2002, EUA.
} 


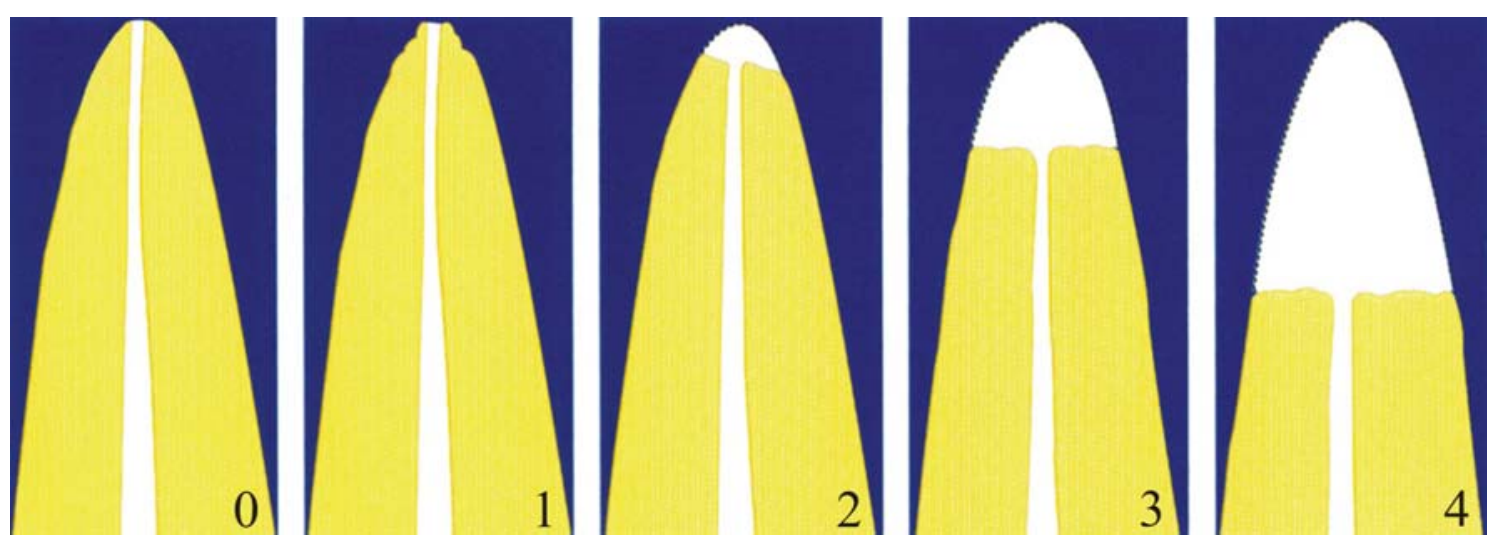

Figura 3 - Classificação dos graus de reabsorção, segundo Levander \& Malmgren $^{77}$

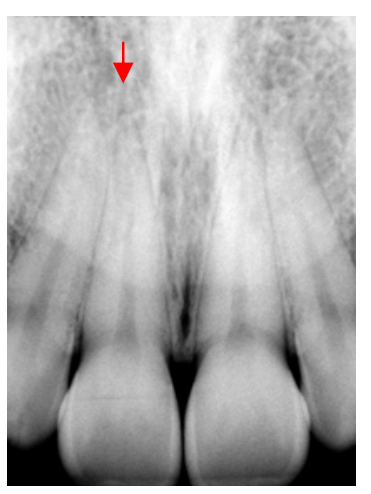

Grau 0

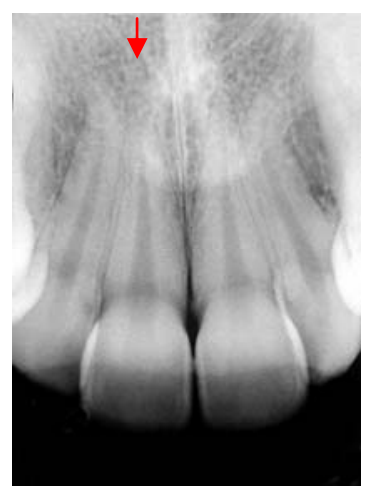

Grau 1

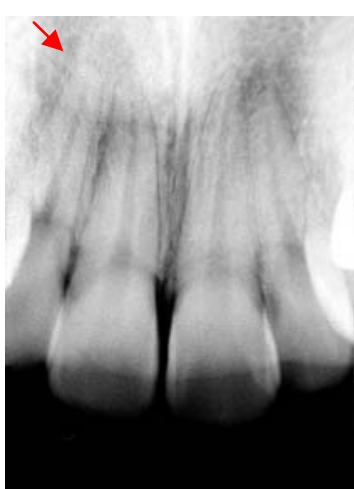

Grau 2

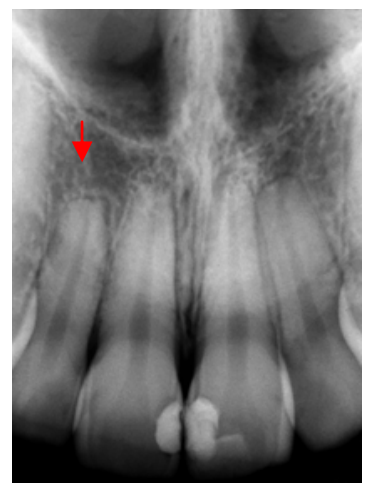

Grau 3

Figura 4 - Radiografias periapicais dos incisivos superiores

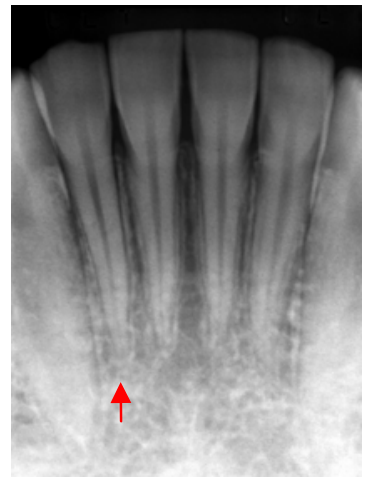

Grau 0

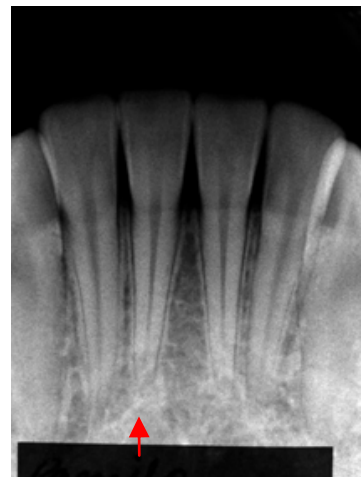

Grau 1

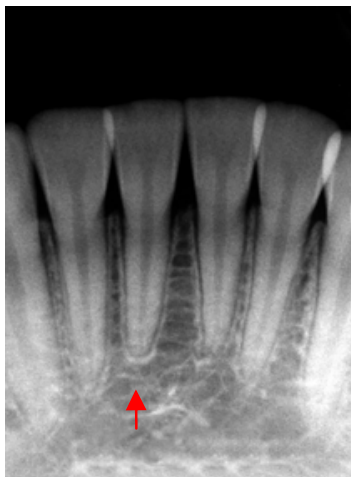

Grau 2

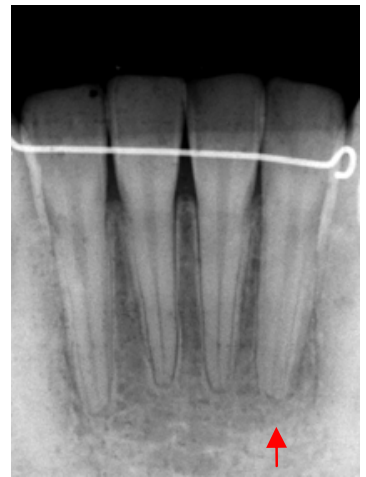

Grau 3

Figura 5 - Radiografias periapicais dos incisivos inferiores 
Para evitar tendenciosidade, um mesmo examinador conduziu a leitura das radiografias sem que se soubesse a que grupo as mesmas pertenciam (estudo cego), embora alguns pacientes que receberam tratamento fixo e que apresentavam contenção fixa inferior fossem distinguidos mais facilmente dos demais. A seqüência de leitura das radiografias foi definida aleatoriamente.

\subsection{Análise Estatística}

\subsubsection{Erro do método}

Com a intenção de avaliar o grau de concordância intra-examinador, instituiu-se a medição da reprodutibilidade do exame radiográfico. Trinta casos foram selecionados aleatoriamente (dez de cada grupo) e medidos novamente pelo mesmo examinador (erro intra-examinador). As medidas repetidas foram testadas pelo coeficiente Kappa (א) ou Cohen's kappa para a obtenção dos valores de concordância, de acordo com LANDIS \& $\mathrm{KOCH}^{74}$ no qual assim o qualifica:

\begin{tabular}{|c|c|}
\hline$\kappa$ & Confiabilidade \\
\hline$<0,00$ & - \\
\hline $0,00-0,20$ & Baixo \\
\hline $0,21-0,40$ & Médio \\
\hline $0,41-0,60$ & Moderado \\
\hline $0,61-0,80$ & Substancial \\
\hline $0,81-1,00$ & quase perfeito \\
\hline
\end{tabular}

O cálculo é realizado por meio da seguinte fórmula:

$$
\kappa=\frac{P o-P e}{100-P e}
$$


Onde:

Po $=$ porcentagem de dentes nos quais houve concordância diagnóstica;

$\mathrm{Pe}=$ porcentagem de concordância esperada

O cálculo foi realizado mediante o emprego de uma planilha do Microsoft Excel $X \mathrm{p}^{\mathrm{a}}$. Os valores expressando a concordância entre os métodos e o padrão obedeceu à escala do Cohen's kappa ${ }^{74}$.

\subsubsection{Comparações entre os grupos}

- Compatibilidade dos grupos

Para verificar se existem diferenças com relação à idade inicial e tempo de tratamento entre os grupos e subgrupos que receberam tratamento, aplicouse $o$ teste $t$ de Student. Para a verificação da compatibilidade da idade no momento da tomada radiográfica, para os três grupos, foi empregada a análise de variância - Anova. A diferença dos grupos com respeito à proporção entre os gêneros foi comparada pelo teste não-paramétrico Qui-quadrado (teste $\mathrm{X}^{2}$ ). Os resultados foram considerados estatisticamente significantes para $p<0,05$.

- Quantidade de reabsorção

$\mathrm{Na}$ análise das radiografias periapicais, a quantidade de reabsorção, para os três grupos, foi comparada por meio do teste não-paramétrico KruskalWallis $^{28}$ (teste $\mathrm{H}$ ). A presença de diferença estatisticamente significante foi evidenciada quando a variável apresentava $p<0,05$. Nestes casos, aplicou-se o teste de Dunn ${ }^{28}$ para comparações individuais com o objetivo de localizar as diferenças detectadas.

\footnotetext{
${ }^{a}$ Copyright $^{\circledR}$ Microsoft Corporation 1985-2001, EUA.
} 
Como havia pacientes que receberam terapia complementar com ortodontia fixa nos grupos 1 e 2, que poderia influenciar na quantidade de reabsorção, foi estabelecido os subgrupos 1.1, 1.2, 2.1 e 2.2. Nos subgrupos 1.1 e 2.1 se encontram os pacientes que receberam somente tratamento ortodôntico com aparelhos removíveis, referentes ao aparelho de Fränkel e aos Guias de Erupção, respectivamente. Por sua vez, os subgrupos 1.2 e 2.2 se caracterizam pelos pacientes que receberam finalização com aparelhos fixos, sendo o subgrupo 1.2 submetido ao tratamento com o Fränkel e o subgrupo 2.2 aos Guias de Erupção. Dessa forma, permitiu-se que as diferentes modalidades de tratamento fossem comparadas com o propósito de distinção da variável em questão. O mesmo teste Kruskal-Wallis foi utilizado para a avaliação entre os subgrupos, em comparação com o grupo controle.

Para a análise entre os subgrupos 1.1 e 1.2, e entre os subgrupos 2.1 e 2.2, utilizou-se o teste não-paramétrico Mann-Whitney ${ }^{28}$ (teste $U$ ), para comparação de duas amostras independentes. Estes testes foram realizados com o programa Statisticab.

A avaliação do grau de reabsorção radicular se procedeu para cada grupo de incisivos, separadamente, com distinção entre os lados direito e esquerdo, reunindo um total de 8 avaliações. Em adição, com o propósito de generalizar e facilitar a interpretação dos resultados determinou-se a média dos escores obtidos das avaliações dos incisivos (DM). Para cada paciente, além dos escores conferidos ao grau de reabsorção radicular para os incisivos, a média aritmética desses escores foi calculada e considerada como outra avaliação durante as comparações entre os grupos e subgrupos.

Avaliação complementar

Como é de conhecimento que o poder de qualquer prova nãoparamétrica pode ser elevado aumentando-se o tamanho da amostra ${ }^{28,130}$, e com o intento de simplificar a análise dos resultados obtidos, o cálculo também foi efetuado sem a discriminação das amostras pelo tipo de dente. Considerou-

\footnotetext{
${ }^{\mathrm{b}}$ Statistica for Windows - Release 6.0 - Copyright ${ }^{\circledR}$ Statsoft, Inc. 1984-2001.
} 
se a reabsorção radicular dos incisivos indistintamente, em que os testes estatísticos foram aplicados para somente uma avaliação por escores.

A comparação entre os três grupos foi possível pela aplicação do teste não-paramétrico Kruskal-Wallis. Da mesma forma se procedeu para a comparação dos subgrupos experimentais em relação ao grupo controle. Para a comparação entre os subgrupos 1.1 e 1.2, e entre os subgrupos 2.1 e 2.2, foi aplicado o teste Mann-Whitney.

\subsubsection{Prevalência de reabsorção nos incisivos}

Para avaliar a prevalência de reabsorção radicular decorrente do tratamento com os aparelhos removíveis e fixos, calculou-se a porcentagem de reabsorção encontrada para cada grupo de incisivos, sem distinção entre os lados direito e esquerdo. 
RESULTADOS 


\section{RESULTADOS}

Os resultados se encontram nas tabelas seguintes. A Tabela 1 apresenta os resultados do erro intra-examinador. As Tabelas 2 e 3 retratam os resultados das comparações entre as idades ao início e final do tratamento e a duração dos mesmos em anos, respectivamente. A Tabela 4 apresenta a comparação entre as idades no momento da tomada radiográfica, e a Tabela 5 demonstra a comparação entre os gêneros.

Na Tabela 6 estão expostos os resultados do teste não-paramétrico Kruskal-Wallis para os três grupos avaliados. A Tabela 7 retrata a comparação entre os subgrupos que somente receberam tratamento com aparelhos removíveis e a Tabela 8, os subgrupos que se submeteram ao tratamento com aparelhos removíveis e fixos, em comparação com o grupo controle. Na Tabela 9 estão dispostos os resultados do teste Mann-Whitney para a comparação entre o subgrupo de pacientes que utilizaram o aparelho de Fränkel, exclusivamente, e o subgrupo de pacientes que foram tratados com o aparelho de Fränkel, mas que finalizaram com aparelhos fixos. Similarmente, a Tabela 10 representa a comparação entre o subgrupo de pacientes que somente utilizou os Guias de Erupção com aqueles que complementaram o tratamento com aparelhos fixos.

Nas tabelas subseqüentes, considerou-se a reabsorção radicular indiferentemente ao tipo do incisivo. A Tabela 11 apresenta os resultados da comparação entre os três grupos analisados. A Tabela 12 confronta os resultados entre os subgrupos de pacientes que fizeram uso exclusivamente dos dois tipos de aparelhos removíveis, em comparação com o grupo controle, e a Tabela 13, entre os pacientes que também foram tratados com aparelho fixo. As Tabelas 14 e 15 demonstram as comparações dos subgrupos de pacientes que utilizaram aparelho removível com os pacientes que complementaram o tratamento com aparelho fixo, para o aparelho de Fränkel e o Guia de Erupção, respectivamente. Finalmente, as Tabelas 16 a 19 descrevem a prevalência de reabsorção radicular em cada grupo e subgrupo de pacientes para as diferentes abordagens de tratamento. 
TABELA 1 - Resultados do erro intra-examinador.

\begin{tabular}{|c|c|c|c|}
\hline & $\begin{array}{c}\text { Porcentagem de } \\
\text { concordância (\%) }\end{array}$ & Coeficiente $(\kappa)$ & Confiabilidade \\
\hline D12 & 90,00 & 0,84 & quase perfeito \\
\hline D11 & 83,33 & 0,74 & substancial \\
\hline D21 & 83,33 & 0,71 & substancial \\
\hline D22 & 86,67 & 0,80 & substancial \\
\hline D42 & 86,67 & 0,75 & substancial \\
\hline D41 & 86,67 & 0,78 & substancial \\
\hline D31 & 90,00 & 0,83 & quase perfeito \\
\hline D32 & 83,33 & 0,71 & substancial \\
\hline
\end{tabular}

TABELA 2 - Comparação entre as idades iniciais e finais, pelo teste $t$ de Student.

\begin{tabular}{|c|c|c|c|c|}
\hline & Idade & Fränkel & Guia de Erupção & p \\
\hline Grupo $1 \times 2$ & Média (D.P.) & Média (D.P.) & \\
\hline Subgrupo $1.1 \times 2.1$ & Inicial & $9,69(1,29)$ & $8,17(1,37)$ & 0,000047 \\
\hline Subgrupo $1.2 \times 2.2$ (fase 1) & Inicial & $9,67(1,06)$ & $8,09(1,34)$ & 0,000913 \\
\hline Subgrupo $1.2 \times 2.2$ (fase 2) & Inicial & $9,72(1,54)$ & $8,37(1,47)$ & 0,039029 \\
\hline Grupo $1 \times 2$ & Final & $12,61(1,72)$ & $13,52(1,42)$ & 0,172492 \\
\hline
\end{tabular}

TABELA 3 - Comparação entre os tempos de tratamentos, pelo teste $t$ de Student.

\begin{tabular}{|c|c|c|c|}
\hline & Fränkel & Guia de Erupção & \multirow{2}{*}{ P } \\
\hline & Média (D.P.) & Média (D.P.) & \\
\hline Grupo $1 \times 2$ & $3,59(1,22)$ & $4,51(2,14)$ & 0,061677 \\
\hline Subgrupo $1.1 \times 2.1$ & $3,18(0,96)$ & $3,97(2,12)$ & 0,231707 \\
\hline Subgrupo $1.2 \times 2.2$ (fase 1) & $2,32(0,83)$ & $4,07(1,32)$ & 0,000835 \\
\hline Subgrupo $1.2 \times 2.2$ (fase 2) & $1,67(0,91)$ & $1,68(1,08)$ & 0,981563 \\
\hline
\end{tabular}


TABELA 4 - Comparação entre as idades no momento da tomada radiográfica, pela análise de variância - ANOVA.

\begin{tabular}{|c|c|c|c|c|}
\hline Grupo $1(\mathrm{n}=24)$ & Grupo 2 $(\mathrm{n}=40)$ & Grupo $3(\mathrm{n}=24)$ & $\mathrm{F}$ & $\mathrm{P}$ \\
\hline Média (D.P.) & Média (D.P.) & Média (D.P.) & & \\
\hline $16,97(3,58)^{\mathrm{A}}$ & $16,97(2,56)^{\mathrm{A}}$ & $17,00(3,16)^{\mathrm{A}}$ & 0,001035 & 0,998966 \\
\hline
\end{tabular}

${ }^{\text {A }}$ Diferentes letras representam diferenças estatisticamente significantes

TABELA 5 - Compatibilidade dos grupos entre os gêneros, pelo teste Quiquadrado.

\begin{tabular}{|c|c|c|c|c|c|}
\hline & Grupo 1 $(n=24)$ & Grupo 2 $(n=40)$ & Grupo 3 $(n=24)$ & \multirow{2}{*}{$X^{2}$} & P \\
\hline Feminino & N (\%) & N (\%) & N (\%) & \\
\hline Masculino & $10(41,7)$ & $22(55)$ & $12(50)$ & \multirow{2}{*}{1,0667} & 0,586646 \\
\hline
\end{tabular}

TABELA 6 - Comparação do grau de reabsorção entre os três grupos, pelo teste Kruskal-Wallis.

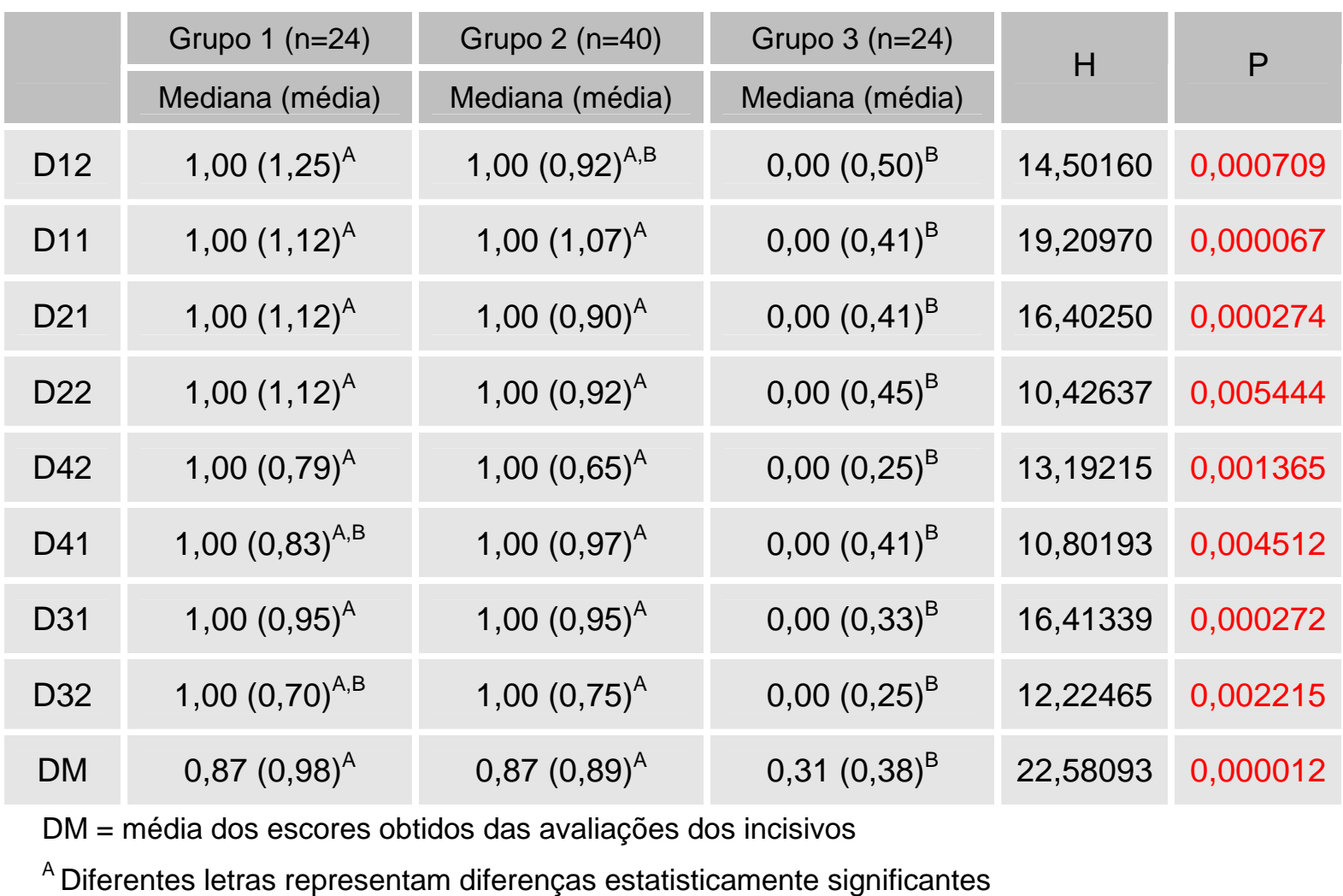


TABELA 7 - Comparação do grau de reabsorção entre os subgrupos 1.1, 2.1 e o grupo controle, pelo teste Kruskal-Wallis.

\begin{tabular}{|c|c|c|c|c|c|}
\hline & Subgrupo $1.1(n=12)$ & Subgrupo $2.1(n=28)$ & Grupo $3(n=24)$ & \multirow{2}{*}{$\mathrm{H}$} & \multirow{2}{*}{$p$} \\
\hline & Mediana (média) & Mediana (média) & Mediana (média) & & \\
\hline $\mathrm{D} 12$ & $1,00(0,91)^{A}$ & $1,00(0,85)^{A}$ & $0,00(0,50)^{A}$ & 5,666843 & 0,058811 \\
\hline D11 & $1,00(0,66)^{A, B}$ & $1,00(1,00)^{A}$ & $0,00(0,41)^{B}$ & 14,93344 & 0,000571 \\
\hline $\mathrm{D} 21$ & $1,00(0,75)^{A, B}$ & $1,00(0,82)^{A}$ & $0,00(0,41)^{B}$ & 9,063267 & 0,010763 \\
\hline D22 & $0,50(0,58)^{A}$ & $1,00(0,71)^{A}$ & $0,00(0,45)^{A}$ & 3,549820 & 0,169498 \\
\hline D42 & $1,00(0,58)^{A, B}$ & $1,00(0,57)^{\mathrm{A}}$ & $0,00(0,25)^{B}$ & 6,298522 & 0,042883 \\
\hline D41 & $1,00(0,58)^{A, B}$ & $1,00(0,92)^{A}$ & $0,00(0,41)^{B}$ & 9,434482 & 0,008939 \\
\hline D31 & $1,00(0,91)^{A, B}$ & $1,00(0,85)^{A}$ & $0,00(0,33)^{B}$ & 12,88885 & 0,001589 \\
\hline D32 & $0,00(0,33)^{A, B}$ & $1,00(0,64)^{A}$ & $0,00(0,25)^{B}$ & 9,197368 & 0,010065 \\
\hline DM & $0,68(0,66)^{A, B}$ & $0,87(0,79)^{A}$ & $0,31(0,38)^{\mathrm{B}}$ & 15,26457 & 0,000484 \\
\hline
\end{tabular}

TABELA 8 - Comparação do grau de reabsorção entre os subgrupos 1.2, 2.2 e o grupo controle, pelo teste Kruskal-Wallis.

\begin{tabular}{|c|c|c|c|c|c|}
\hline & Subgrupo $1.2(n=12)$ & Subgrupo $2.2(n=12)$ & Grupo $3(n=24)$ & \multirow{2}{*}{$\mathrm{H}$} & \multirow{2}{*}{$\mathrm{p}$} \\
\hline & Mediana (média) & Mediana (média) & Mediana (média) & & \\
\hline D12 & $1,50(1,58)^{A}$ & $1,00(1,08)^{A, B}$ & $0,00(0,50)^{B}$ & 18,13120 & 0,000115 \\
\hline D11 & $1,00(1,58)^{A}$ & $1,00(1,25)^{A}$ & $0,00(0,41)^{\mathrm{B}}$ & 19,80618 & 0,000050 \\
\hline D21 & $1,00(1,50)^{A}$ & $1,00(1,08)^{A}$ & $0,00(0,41)^{B}$ & 17,59520 & 0,000151 \\
\hline D22 & $2,00(1,66)^{A}$ & $1,00(1,41)^{A}$ & $0,00(0,45)^{B}$ & 20,44713 & 0,000036 \\
\hline D42 & $1,00(1,00)^{A}$ & $1,00(0,83)^{A}$ & $0,00(0,25)^{\mathrm{B}}$ & 16,70914 & 0,000235 \\
\hline D41 & $1,00(1,08)^{A, B}$ & $1,00(1,08)^{A}$ & $0,00(0,41)^{B}$ & 9,276105 & 0,009676 \\
\hline D31 & $1,00(1,00)^{A, B}$ & $1,00(1,16)^{A}$ & $0,00(0,33)^{B}$ & 13,52157 & 0,001158 \\
\hline D32 & $1,00(1,08)^{A}$ & $1,00(1,00)^{A}$ & $0,00(0,25)^{B}$ & 15,23365 & 0,000492 \\
\hline DM & $1,25(1,31)^{A}$ & $1,06(1,11)^{A}$ & $0,31(0,38)^{B}$ & 23,91533 & 0,000006 \\
\hline
\end{tabular}


TABELA 9 - Comparação do grau de reabsorção entre o subgrupo 1.1 e o subgrupo 1.2, pelo teste Mann-Whitney.

\begin{tabular}{|c|c|c|c|c|}
\hline & Subgrupo 1.1 (n=12) & Subgrupo $1.2(n=12)$ & U \\
\hline & Mediana (média) & Mediana (média) & \\
\hline D12 & $1,00(0,91)$ & $1,50(1,58)$ & 40,50 & 0,050331 \\
\hline D11 & $1,00(0,66)$ & $1,00(1,58)$ & 29,50 & 0,007015 \\
\hline D21 & $1,00(0,75)$ & $1,00(1,50)$ & 33,50 & 0,012342 \\
\hline D22 & $0,50(0,58)$ & $2,00(1,66)$ & 25,50 & 0,004838 \\
\hline D42 & $1,00(0,58)$ & $1,00(1,00)$ & 47,00 & 0,091540 \\
\hline D41 & $1,00(0,58)$ & $1,00(1,08)$ & 48,50 & 0,145173 \\
\hline D31 & $1,00(0,91)$ & $1,00(1,00)$ & 68,00 & 0,803872 \\
\hline D32 & $0,00(0,33)$ & $1,00(1,08)$ & 36,00 & 0,022702 \\
\hline DM & $0,68(0,66)$ & $1,25(1,31)$ & 27,00 & 0,009191 \\
\hline
\end{tabular}

TABELA 10 - Comparação do grau de reabsorção entre o subgrupo 2.1 e o subgrupo 2.2, pelo teste Mann-Whitney.

\begin{tabular}{|c|c|c|c|c|}
\hline & Subgrupo $2.1(\mathrm{n}=28)$ & Subgrupo $2.2(\mathrm{n}=12)$ & $\mathrm{U}$ \\
\hline & Mediana (média) & Mediana (média) & \\
\hline D12 & $1,00(0,85)$ & $1,00(1,08)$ & 135,00 & 0,213488 \\
\hline D11 & $1,00(1,00)$ & $1,00(1,25)$ & 129,00 & 0,114217 \\
\hline D21 & $1,00(0,82)$ & $1,00(1,08)$ & 129,00 & 0,098302 \\
\hline D22 & $1,00(0,71)$ & $1,00(1,41)$ & 70,00 & 0,000465 \\
\hline D42 & $1,00(0,57)$ & $1,00(0,83)$ & 124,00 & 0,116084 \\
\hline D41 & $1,00(0,92)$ & $1,00(1,08)$ & 147,00 & 0,472105 \\
\hline D31 & $1,00(0,85)$ & $1,00(1,16)$ & 124,00 & 0,107263 \\
\hline D32 & $1,00(0,64)$ & $1,00(1,00)$ & 118,00 & 0,077487 \\
\hline DM & $0,87(0,79)$ & $1,06(1,11)$ & 71,00 & 0,003838 \\
\hline
\end{tabular}


TABELA 11 - Comparação do grau de reabsorção entre os três grupos, sem discriminação pelo tipo de dente, por meio do teste Kruskal-Wallis.

\begin{tabular}{|c|c|c|c|c|c|}
\hline & Grupo $1(n=192)$ & Grupo $2(n=320)$ & Grupo 3 $(n=192)$ & H & p \\
\hline & Mediana (média) & Mediana (média) & Mediana (média) & & \\
\hline Incisivos & $1,00(0,98)^{A}$ & $1,00(0,89)^{A}$ & $0,00(0,38)^{B}$ & 104,3488 & 0,000000 \\
\hline
\end{tabular}

TABELA 12 - Comparação do grau de reabsorção entre os subgrupos 1.1, 2.1 e o grupo controle, sem discriminação pelo tipo de dente, por meio do teste Kruskal-Wallis.

\begin{tabular}{|c|c|c|c|c|c|}
\hline & Subgrupo 1.1 $(\mathrm{n}=96)$ & Subgrupo 2.1(n=224) & Grupo 3 $(\mathrm{n}=192)$ & $\mathrm{H}$ & $\mathrm{p}$ \\
\hline & Mediana (média) & Mediana (média) & Mediana (média) & & \\
\hline Incisivos & $1,00(0,66)^{\mathrm{A}}$ & $1,00(0,79)^{\mathrm{A}}$ & $0,00(0,38)^{\mathrm{B}}$ & 62,59848 & 0,000000 \\
\hline
\end{tabular}

TABELA 13 - Comparação do grau de reabsorção entre os subgrupos 1.2, 2.2 e o grupo controle, sem discriminação pelo tipo de dente, por meio do teste Kruskal-Wallis.

\begin{tabular}{|c|c|c|c|c|c|}
\hline & Subgrupo $1.2(n=96)$ & Subgrupo $2.2(n=96)$ & Grupo $3(n=192)$ & H & p \\
\hline Mediana (média) & Mediana (média) & Mediana (média) & & \\
\hline Incisivos & $1,00(1,31)^{A}$ & $1,00(1,11)^{A}$ & $0,00(0,38)^{B}$ & 124,2326 & 0,000000 \\
\hline
\end{tabular}

TABELA 14 - Comparação do grau de reabsorção entre o subgrupo 1.1 e o subgrupo 1.2, sem discriminação pelo tipo de dente, pelo teste Mann-Whitney.

\begin{tabular}{|c|c|c|c|c|}
\hline & Subgrupo $1.1(n=96)$ & Subgrupo $1.2(n=96)$ & \multirow{2}{*}{ U } \\
\hline & Mediana (média) & Mediana (média) & \\
\hline Incisivos & $1,00(0,66)$ & $1,00(1,31)$ & 2624,00 & 0,000000 \\
\hline
\end{tabular}

TABELA 15 - Comparação do grau de reabsorção entre o subgrupo 2.1 e o subgrupo 2.2, sem discriminação pelo tipo de dente, pelo teste Mann-Whitney.

\begin{tabular}{|c|c|c|c|c|}
\hline & Subgrupo 2.1 $(\mathrm{n}=224)$ & Subgrupo $2.2(\mathrm{n}=96)$ & $\mathrm{U}$ & $\mathrm{p}$ \\
\hline Mediana (média) & Mediana (média) & & \\
\hline Incisivos & $1,00(0,79)$ & $1,00(1,11)$ & 7887,50 & 0,000003 \\
\hline
\end{tabular}


TABELA 16 - Prevalência de reabsorção radicular nos três grupos estudados, de grau leve a moderado (escores 1 e 2).

\begin{tabular}{|c|c|c|c|c|c|c|}
\hline & \multicolumn{2}{|c|}{ Grupo 1 $(\mathrm{n}=24)$} & \multicolumn{2}{|c|}{ Grupo 2 $(\mathrm{n}=40)$} & \multicolumn{2}{|c|}{ Grupo 3 $(\mathrm{n}=24)$} \\
\hline & Prev. ${ }^{*}$ & $\%$ & Prev. & $\%$ & Prev. & $\%$ \\
\hline ILS & $34 / 192$ & 17,70 & $65 / 320$ & 20,31 & $21 / 192$ & 10,90 \\
\hline ICS & $36 / 192$ & 18,80 & $71 / 320$ & 22,19 & $16 / 192$ & 8,30 \\
\hline ILI & $29 / 192$ & 15,10 & $54 / 320$ & 16,88 & $11 / 192$ & 5,70 \\
\hline ICI & $32 / 192$ & 16,70 & $65 / 320$ & 20,31 & $18 / 192$ & 9,40 \\
\hline Arco sup. & $70 / 192$ & 36,50 & $136 / 320$ & 42,50 & $37 / 192$ & 19,20 \\
\hline Arco inf. & $61 / 192$ & 31,80 & $119 / 320$ & 37,19 & $29 / 192$ & 15,10 \\
\hline Total & $131 / 192$ & 68,30 & $255 / 320$ & 79,69 & $66 / 192$ & 34,30 \\
\hline
\end{tabular}

*Correspondente ao número de raízes reabsorvidas / número de raízes examinadas

TABELA 17 - Prevalência de reabsorção radicular nos três grupos estudados, de grau acentuado (escore 3).

\begin{tabular}{|c|c|c|c|c|c|c|}
\hline & \multicolumn{2}{|c|}{ Grupo 1 $(n=24)$} & \multicolumn{2}{|c|}{ Grupo 2 $(n=40)$} & \multicolumn{2}{c|}{ Grupo 3 $(n=24)$} \\
\hline & Prev. & $\%$ & Prev. & $\%$ & Prev & $\%$ \\
\hline ILS & $3 / 192$ & 1,56 & 0 & 0,00 & 0 & 0,00 \\
\hline ICS & $3 / 192$ & 1,56 & 0 & 0,00 & 0 & 0,00 \\
\hline ILI & $1 / 192$ & 0,52 & 0 & 0,00 & 0 & 0,00 \\
\hline ICI & 0 & 0,00 & 0 & 0,00 & 0 & 0,00 \\
\hline Arco sup. & $6 / 192$ & 3,12 & 0 & 0,00 & 0 & 0,00 \\
\hline Arco inf. & $1 / 192$ & 0,52 & 0 & 0,00 & 0 & 0,00 \\
\hline Total & $7 / 192$ & 3,64 & 0 & 0,00 & 0 & 0,00 \\
\hline
\end{tabular}


TABELA 18 - Prevalência de reabsorção radicular nos subgrupos 1.1, 1.2, 2.1 e 2.2, de grau leve a moderado (escores 1 e 2).

\begin{tabular}{|c|c|c|c|c|c|c|c|c|}
\hline & \multicolumn{3}{|c|}{ Subgrupo $1.1(\mathrm{n}=12)$} & \multicolumn{2}{|c|}{ Subgrupo $1.2(\mathrm{n}=12)$} & \multicolumn{2}{|c|}{ Subgrupo $2.1(\mathrm{n}=28)$} & \multicolumn{2}{|c|}{ Subgrupo $2.2(\mathrm{n}=12)$} \\
\hline & Prev. & $\%$ & Prev. & $\%$ & Prev & $\%$ & Prev & $\%$ \\
\hline ILS & $14 / 96$ & 14,58 & $20 / 96$ & 20,83 & $42 / 224$ & 18,75 & $23 / 96$ & 23,96 \\
\hline ICS & $15 / 96$ & 15,63 & $21 / 96$ & 21,88 & $49 / 224$ & 21,88 & $22 / 96$ & 22,92 \\
\hline ILI & $11 / 96$ & 11,46 & $18 / 96$ & 18,75 & $34 / 224$ & 15,18 & $20 / 96$ & 20,83 \\
\hline ICI & $16 / 96$ & 16,67 & $16 / 96$ & 16,67 & $44 / 224$ & 19,64 & $21 / 96$ & 21,88 \\
\hline Arco sup. & $29 / 96$ & 30,21 & $41 / 96$ & 42,71 & $91 / 224$ & 40,63 & $45 / 96$ & 46,88 \\
\hline Arco inf. & $27 / 96$ & 28,13 & $34 / 96$ & 35,42 & $78 / 224$ & 34,82 & $41 / 96$ & 42,71 \\
\hline Total & $56 / 96$ & 58,34 & $75 / 96$ & 78,13 & $169 / 224$ & 75,45 & $86 / 96$ & 89,59 \\
\hline
\end{tabular}

TABELA 19 - Prevalência de reabsorção radicular nos subgrupos 1.1, 1.2, 2.1 e 2.2, de grau acentuado (escore 3).

\begin{tabular}{|c|c|c|c|c|c|c|c|c|}
\hline & \multicolumn{2}{|c|}{ Subgrupo $1.1(n=12)$} & \multicolumn{2}{|c|}{ Subgrupo $1.2(n=12)$} & \multicolumn{2}{|c|}{ Subgrupo $2.1(n=28)$} & \multicolumn{2}{|c|}{ Subgrupo $2.2(n=12)$} \\
\hline & Prev. & $\%$ & Prev. & $\%$ & Prev. & $\%$ & Prev. & $\%$ \\
\hline ILS & 0 & 0 & $3 / 96$ & 3,13 & 0 & 0,00 & 0 & 0,00 \\
\hline ICS & 0 & 0 & $3 / 96$ & 3,13 & 0 & 0,00 & 0 & 0,00 \\
\hline ILI & 0 & 0 & $1 / 96$ & 1,04 & 0 & 0,00 & 0 & 0,00 \\
\hline ICI & 0 & 0 & 0 & 0,00 & 0 & 0,00 & 0 & 0,00 \\
\hline Arco sup. & 0 & 0 & $6 / 96$ & 6,26 & 0 & 0,00 & 0 & 0,00 \\
\hline Arco inf. & 0 & 0 & $1 / 96$ & 1,04 & 0 & 0,00 & 0 & 0,00 \\
\hline Total & 0 & 0 & $7 / 96$ & 7,30 & 0 & 0,00 & 0 & 0,00 \\
\hline
\end{tabular}


DISCUSSÃO 


\section{DISCUSSÃO}

Com o objetivo de melhor compreensão da discussão dos resultados obtidos, este capítulo foi dividido em tópicos, considerando-se vários fatores relacionados ao desenvolvimento desta pesquisa. Desse modo, discutir-se-ão, primeiramente, as características da amostra levando-se em consideração a sua composição e a compatibilidade entre os grupos. A seguir, serão feitas considerações sobre a metodologia empregada e, por fim, analisar-se-ão os resultados verificados nas comparações inter e intragrupos com respeito à quantidade e à prevalência de reabsorção.

\subsection{A amostra}

A representatividade de uma amostra é importante para que os dados coletados sejam extrapolados para a população ${ }^{28}$. Entretanto, o correto dimensionamento da amostra torna-se uma tarefa complexa e, muitas vezes, independe da boa vontade do pesquisador.

Este estudo se comporta de maneira retrospectiva, pois a coleta dos dados é realizada antes do planejamento da pesquisa, como parte dos dados da documentação ortodôntica. A seleção da amostra talvez seja o ponto vulnerável desse modelo de pesquisa, por favorecer apenas casos completamente finalizados. Como conseqüência, as conclusões só se aplicam ao grupo estudado, ou a grupos similares, e não podem ser extrapolados para a população em geral.

Na seleção dos casos do presente trabalho, houve uma diminuição do número de componentes da amostra. Um dos critérios utilizados baseou-se na obtenção dos casos com tratamento concluído, ressaltando-se que a colaboração dos pacientes e a realização da fase de aparelhos fixos sem extrações constituíram critérios decisivos para a inclusão na amostra.

Para compor o grupo experimental 1, verificou-se inicialmente uma amostra de 38 pacientes tratados com o Regulador de Função de Fränkel $^{41}$ pelos alunos do curso de pós-graduação, ao nível de mestrado, da Faculdade 
de Odontologia de Bauru. Destes pacientes pré-selecionados, oito pacientes interromperam o tratamento por motivo de desistência ${ }^{65}$. Outros seis pacientes foram excluídos por razões diversas, como não apresentar a documentação necessária para a realização da pesquisa, recusa em fazer o controle póstratamento, falta de colaboração ou mudança de cidade. Portanto, do total de 38, foram selecionados 24 pacientes para a composição deste grupo, o que representa $63,15 \%$ da amostra. O propósito de incluir três pacientes com má oclusão de Classe III e dois com má oclusão de Classe II, divisão 2, foi de ampliar a amostra e com isso tornar consistentes os resultados. Por se tratarem de discrepâncias suaves, que não necessitaram de extrações dentárias ou mesmo cirurgia ortognática, a diferença no tipo de má oclusão foi consentida $^{144}$.

O grupo experimental 2, composto por 40 pacientes, receberam tratamento com o aparelho Guia de Erupção pelos alunos de pós-graduação ao nível de mestrado da Faculdade de Odontologia de Bauru. Estes 40 pacientes foram selecionados de uma pré-avaliação de um total de 60 pacientes, correspondente a $66,66 \%$ da amostra total, que durante o tratamento mostraram-se colaboradores. Em relação ao número de pacientes desistentes, onze pacientes não estavam dispostos a prosseguirem com o tratamento ${ }^{65}$. Adicionalmente, outros nove pacientes foram excluídos por falta de cooperação com o uso do aparelho, pela ausência de documentação necessária, ou por mudança de endereço.

Na realização de uma pesquisa clínica, em que uma amostra constitui-se de pacientes tratados por diferentes profissionais, muitas variáveis devem ser consideradas e, entre elas, a dificuldade de uma maior padronização metodológica. Preferencialmente, os casos tratados constituintes da amostra deveriam ter sido conduzidos por apenas um profissional ${ }^{126}$. Porém, em termos de casuística, torna-se muito difícil conseguir uma amostra de tamanho considerável para realizar uma pesquisa desse tipo. KROGMAN"3 já disse: "Em pesquisa, pode-se visar a perfeição, porém a adequação constitui o padrão na maioria das vezes utilizado". Além disso, existem outros trabalhos na literatura realizados com amostras de diferentes procedências, tratadas por diferentes operadores, e que não ressaltam que esse fator possa interferir nos resultados 
obtidos $^{47,63}$. Na pesquisa realizada por BAUMRIND; KORN; BOYD ${ }^{8}$, em 1996, o material foi levantado de 81 pacientes tratados em três clínicas diferentes. REMINGTON et al. ${ }^{116}$, em 1989, por sua vez, proveu o seu material de pesquisa das documentações de pacientes tratados no Departamento de Ortodontia da Universidade de Washington e de várias clínicas particulares na região de Seattle.

Não obstante os pacientes desta pesquisa tenham sido tratados por diferentes profissionais, todos tiveram a mesma procedência, ou seja, foram tratados na mesma instituição, além de o diagnóstico, o planejamento dos casos e a supervisão dos pacientes durante o tratamento serem conduzidos por um único operador. Ademais, as amostras que compuseram os grupos tratados com os dois tipos de aparelhos consistiram em pesquisas já realizadas $^{58,64}$, que se caracterizaram como sendo prospectivas, com um acompanhamento da evolução dos casos por um período mínimo de dois anos, propiciando um protocolo de tratamento similar para todos os componentes dos grupos.

Pela indicação do tratamento ortopédico com aparelhos removíveis ser direcionado a crianças e adolescentes, os incisivos encontravam-se íntegros na maioria das vezes, um ou outro apresentando restaurações por motivo de cárie. Dessa forma não se observou dentes apresentando tratamento endodôntico e, por isso, esse fator não se mostrou uma preocupação para o presente estudo.

Mesmo selecionando os pacientes de ambos os grupos de acordo com os critérios mencionados, há possibilidade dos mesmos apresentarem características diferentes em algumas variáveis. Dessa forma, em relação à idade inicial de tratamento entre os grupos, verificou-se que o grupo 2 apresentou uma média de idade estatisticamente mais baixa que o grupo 1 (Tabela 2). O mesmo ocorreu com o subgrupo 2.1 em relação ao subgrupo 1.1, e na comparação entre os subgrupos 2.2 e 1.2, no período de uso dos aparelhos removíveis. Este fato parece estar relacionado à explicação de que 10 pacientes tratados com os Guias de Erupção iniciaram a terapia numa idade precoce, ao final da dentadura decídua, com os dispositivos pertencentes à série "C" (Nite guide), indicado para corrigir as más oclusões nas dentaduras 
decídua e mista precoce, numa faixa etária entre 5 e 7 anos. Entretanto, como as idades no momento da tomada radiográfica e o tempo de tratamento são semelhantes, a diferença das idades iniciais terá pouca influência nos resultados obtidos. Além disso, como o objetivo do trabalho é avaliar a quantidade de reabsorção radicular proveniente do uso de cada um dos aparelhos, os mesmos devem ser utilizados nas faixas etárias em que produzem um melhor resultado e em que estão preconizados ${ }^{132}$.

Com respeito ao tempo de tratamento, algumas considerações devem ser feitas. Verificou-se compatibilidade estatística entre os dois grupos experimentais com respeito ao tempo médio de tratamento (Tabela 3). 0 mesmo ocorreu quando se compararam os subgrupos de pacientes que fizeram uso dos aparelhos removíveis, exclusivamente. A tendência para um maior tempo de tratamento necessário para a correção da má oclusão com os Guias de Erupção, presente neste trabalho, já foi demonstrada em estudo recente. JANSON et al. ${ }^{59}$ compararam as alterações oclusais promovidas pelos Guias de Erupção e o aparelho de Fränkel, utilizando pacientes da presente investigação. Antecipadamente, os autores verificaram a necessidade de um tempo maior de tratamento para a correção da má oclusão de Classe II com os Guias de Erupção. Salientaram ser este fator uma outra variável a se considerar durante a tomada de decisão sobre qual aparelho removível utilizar para o tratamento. Em relação ao presente trabalho, também se deve reputar o fato de alguns pacientes terem iniciado o tratamento com os Guias de Erupção numa idade média mais precoce, ao final do período da dentadura decídua. No entanto, para ambos os grupos, o final do tratamento ocorreu aproximadamente à mesma idade, com o início da dentadura permanente, ao final do surto de crescimento pubescente ${ }^{106}$ (Tabela 2). O tempo de tratamento nessa idade pode ter se prolongado. Todavia, apesar de suavemente aumentado para o grupo dos Guias de Erupção, no presente trabalho o tempo de tratamento não parece se relacionar com o ao grau de reabsorção radicular, conforme será explicado posteriormente.

De maneira contrária, ao avaliar a compatibilidade do tempo de tratamento entre os subgrupos 1.2 e 2.2, o teste estatístico acusou diferença significante entre os mesmos (Tabela 3). A divisão do tempo de tratamento em 
duas fases para a comparação entre os pacientes que finalizaram o tratamento com aparelhos fixos permitiu determinar a procedência dessa divergência. $A$ segunda fase de tratamento apresentou similaridade estatística entre os subgrupos, eliminando dúvidas quanto ao tempo de tratamento dos aparelhos fixos, considerados os maiores determinantes de reabsorção radicular ${ }^{30,80,115}$. Na observação do período de utilização dos aparelhos removíveis, o subgrupo 1.2 apresentou um tempo estatisticamente reduzido em relação ao subgrupo 2.2. Entretanto, este fator não parece influenciar nos resultados obtidos, conforme será descrito em tópico posterior.

Em estudo prévio realizado ${ }^{59}$, verificou-se um tempo de tratamento de 24 meses necessário para corrigir a má oclusão com o aparelho de Fränkel, e de 28 meses com os Guias de Erupção. Em contraste, a presente investigação apresentou uma tendência para um tempo de tratamento mais longo para as duas formas de abordagens (Tabela 3). O desacordo entre os dois estudos pode se encontrar no critério da estipulação do término do tratamento. Para a avaliação da proporção de sucesso dos dois tipos de aparelhos, os autores consideraram o tratamento finalizado quando da obtenção dos modelos de estudo, após a correção da má oclusão. Entretanto, no presente estudo, como descrito previamente, para a avaliação do grau de reabsorção incluiu-se o período de contenção ativa com o uso do próprio aparelho removível, por também se tratar de um período passível de ocorrer reabsorção radicular.

Ao se compararem os três grupos levando-se em consideração a idade dos pacientes na época da última tomada radiográfica (Tabela 4), foi identificado valores bastante próximos, denotando alta compatibilidade, eliminando dessa forma possíveis influências da idade na quantidade de reabsorção encontrada ${ }^{20}$, apesar de o fator idade, entre 11,5 e 25 anos, segundo LINGE \& LINGE $^{81}$, não parecer refletir um processo de envelhecimento significante para as estruturas radiculares.

No presente estudo optou-se pelo método transversal de pesquisa, compreendendo a realização de um único exame, ou seja, pela comparação entre os grupos formados por pacientes tratados ortodonticamente por duas diferentes técnicas e o grupo de pacientes não submetidos ao tratamento ortodôntico. Isto porque muitas vezes a documentação ortodôntica inicial, 
necessária para a pesquisa, não se apresentava completa, ou as radiografias iniciais não se encontravam padronizadas, não sendo indicadas para avaliação em trabalhos comparativos longitudinais. As radiografias iniciais foram analisadas em relação à reabsorção radicular estabelecida previamente ao tratamento $^{20}$, mas a classificação da magnitude foi determinada apenas nas radiografias finais. GOLDSON \& HENRIKSON ${ }^{48}$ comprovaram que pacientes com reabsorção radicular prévia ao tratamento apresentam grande reabsorção radicular após o término do mesmo. No presente estudo não se verificaram ocorrências desta natureza, e na ficha dos pacientes não houve relatos de problemas desse tipo.

De maneira semelhante deveria ser analisado o grupo controle. Idealmente seria interessante a observação de indivíduos que nunca se submeteram a tratamento ortodôntico pelo mesmo período de tempo médio de tratamento, com o propósito de descartar a possibilidade de que as reabsorções dentárias encontradas durante 0 tratamento não sejam decorrentes do uso normal dos dentes durante um certo período de vida do paciente $^{31,87}$. Essa aproximação, entretanto, se coloca mais na teoria do que na realidade, visto que existe grande limitação do ponto de vista ético.

Na tentativa de estudar a influência do tratamento sobre as estruturas radiculares, a utilização de um grupo controle o mais compatível possível aos grupos experimentais foi considerada no momento da seleção. Observou-se, além das características da má oclusão, a idade e o gênero. Com relação à idade, é possível notar alto grau de compatibilidade entre os três grupos (Tabela 4). O grupo controle apresenta-se bem equilibrado com relação aos gêneros. Entretanto, não foi possível alcançar um equilíbrio, quanto a esse aspecto, nos grupos experimentais, pois isso implicaria em uma redução no tamanho da amostra (Tabela 5). Contudo esse fato não compromete a comparação entre os grupos, pois a diferença na proporção entre os gêneros, para os três grupos analisados, não evidenciou diferença estatisticamente significante. Caso fosse acusada alguma divergência, esta não seria uma limitação para a presente investigação. Alguns trabalhos não encontraram correlação entre a quantidade de reabsorção radicular e a diferença na proporção entre os gêneros ${ }^{66,81,88,94,107}$. Dois estudos, entretanto, concluíram 
que os pacientes do gênero feminino demonstraram maior grau de reabsorção ${ }^{72,97}$; outro encontrou que os pacientes do gênero masculino tiveram maior incidência e severidade ${ }^{133}$. Como os estudos de maior amostragem não evidenciaram diferenças, pode-se assumir que não há diferenças significantes entre os gêneros ${ }^{125}$.

Com relação às características oclusais, os pacientes selecionados para o grupo controle apresentavam má oclusão de Classe II. A possível existência de diferença aos outros grupos não inviabiliza o grupo como parâmetro de comparação $^{95}$. O estudo de VONDERAHE ${ }^{144}$ não encontrou correlação entre reabsorção radicular e a classificação da má oclusão de Angle.

A quantidade de apinhamento suave presente no grupo controle, semelhante aos grupos experimentais, compatibiliza os grupos quanto à morfologia da crista óssea alveolar. As cristas ósseas alveolares de forma triangular, presentes na região dos incisivos, tendem a sofrer maior deflexão óssea e, dessa forma, absorvem parte das forças, diminuindo a chance de lesões na estrutura radicular ${ }^{30}$.

Além do propósito principal do trabalho ter sido comparar o índice de reabsorção dentária entre os dois tipos de aparelhos, e com isso auxiliar na decisão da escolha entre um deles, a comparação com um grupo controle se tornou interessante porque permitiu diferenciar a reabsorção das estruturas radiculares provenientes do uso de aparelhos removíveis em relação a indivíduos que não receberam tratamento algum.

\subsection{A metodologia}

As radiografias periapicais são as mais indicadas para o diagnóstico das reabsorções dentárias, apesar de, em reabsorções linguais e vestibulares, mesmo que médias e largas, em estágios mais avançados também não são apresentadas imagens radiográficas ${ }^{30}$. As radiografias periapicais são muito superiores às panorâmicas, oclusais e cefalométricas laterais, para o estudo de estruturas radiculares, principalmente quando obtidas com a técnica do paralelismo. Vários trabalhos avaliaram o grau de reabsorção radicular apical utilizando a técnica radiográfica do cone longo $5,26,55,77,80,81,94,112$. 
A escolha dos incisivos superiores e inferiores como os dentes alvos para se pesquisar a reabsorção dentária se deve ao fato de ser os dentes que comumente apresentam maior encurtamento e são mais freqüentemente afetados $^{2,3,32,51,66,97,109,125}$, além do padrão monorradiculado e a possibilidade maior de obtenção da imagem radiográfica livre de superposições morfológicas da própria raiz, em decorrência de sua anatomia ${ }^{5,45}$.

A técnica de processamento foi manual, seguindo os critérios do método tempo-temperatura. A análise de radiografias periapicais em imagens tratadas por programas de computador de tratamento de imagens pode ser de grande auxílio no diagnóstico preciso em estágios mais iniciais, pois além de aumentar o tamanho, melhoram determinadas qualidades das imagens radiográficas e permitem visualização de fenômenos menores e mais incipientes ${ }^{30,45}$.

O método de avaliação radiográfica que classifica a reabsorção em 5 escores, de acordo com LEVANDER \& MALMGREN ${ }^{77}$, embora seja pela forma de descrição subjetiva, é utilizado com freqüência no estudo da reabsorção radicular apical subseqüente à movimentação dentária ${ }^{25,26,38,55,78,83,112}$. Sua principal vantagem é o fato de analisar a reabsorção pela sua magnitude, e não depender da padronização da radiografia inicial. LINGE \& LINGE $^{80,81}$ não concordam com esse método e quantificaram a reabsorção por meio da comparação de medidas realizadas nas radiografias pré e pós-tratamento, utilizando um fator de correção para padronização das radiografias. BLAKE; WOODSIDE; PHAROAH ${ }^{16}$ testaram a sua acurácia em crânio seco e verificaram resultados satisfatórios, embora alguns pesquisadores ${ }^{8,94}$ tenham encontrado imprecisões em sua metodologia.

LEVANDER \& MALMGREN ${ }^{77}$, em 1988, ao avaliar o risco de reabsorção radicular apical durante o tratamento ortodôntico, examinaram as radiografias periapicais ao início, depois de 6 a 9 meses e ao final do tratamento, portanto nos períodos em que o processo de reabsorção se encontrava ativo. Nesta situação, quando o dente sofre suave reabsorção, e o seu contorno apical apresenta-se irregular, os autores atribuíram o escore 1, para um sistema classificatório de reabsorção de 0 a 4. Entretanto, quando cessa o fator causal da reabsorção, representado pelo tratamento ortodôntico, a superfície irregular, com áreas delineadas por bordas afiladas e cortantes para os tecidos 
periodontais vizinhos, tende a sofrer uma regularização do ápice. Dessa forma, quando cessa o fator causal da reabsorção e o dente inicia a sua reestruturação apical ele o faz, regularizando as arestas, e com isto ocorre uma perda de tecido dentário apical ${ }^{30,84}$. O período em que a regularidade da superfície se estabelece varia de 5 a 8 semanas da suspensão da força aplicada e pode levar à perda de até $0,1 \mathrm{~mm}$ do comprimento dentário ${ }^{32,104}$. No presente trabalho, o período médio do intervalo entre o término do tratamento ativo e a tomada radiográfica foi de 3,39 anos para o grupo 1 e de 3,95 anos para o grupo 2. Como em alguns pacientes a radiografia periapical foi tomada após um tempo de contenção longo, chegando até ao máximo de 8,91 anos para o subgrupo 1.1 e de até 9,76 anos para o subgrupo 2.1, é de se esperar que ocorra uma remodelação apical. Dessa forma, ao grau 1 de reabsorção, à semelhança de outros pesquisadores ${ }^{25,63,66}$, também se considerou as raízes que apresentavam reabsorção suave, observando-se apenas um arredondamento apical com a raiz apresentando o seu contorno normal, porém, rômbico.

Da mesma forma, cabe uma explicação para o correto significado dos fenômenos biológicos que produziram o abaulamento radicular apical. No presente trabalho, para os incisivos com as raízes totalmente completas, avaliou-se o grau de reabsorção radicular proveniente do tratamento ortodôntico. Entretanto, por se tratar de um grupo de pacientes jovens, com a existência de raízes dentárias que ainda se encontravam em formação, outros mecanismos biológicos também contribuíram para o resultado final da avaliação.

A época de formação final do terço apical da raiz do incisivo central inferior se encontra em torno dos 9 anos de idade. O incisivo lateral inferior apresenta o término da formação radicular aos 10 anos. Já o incisivo central e lateral superior têm suas raízes formadas aos 10 e 11 anos, respectivamente ${ }^{82}$. Pode-se considerar que, aos 11 anos, em média, todos os incisivos permanentes já tiveram a calcificação das raízes completada ${ }^{80}$. A aplicação de forças ortodônticas intensas antes dessa idade, ou seja, em dentes com rizogênese incompleta, pode causar um encurtamento em relação ao que seria o comprimento original do dente, pois a redução do suprimento sangüíneo 
pode levar a uma maturação precoce da papila em polpa dentária e do folículo dentário apical em ligamento periodontal. O término apical se fará mais precocemente $^{56}$. Por esse motivo se recomendam forças aplicadas de baixa ou média intensidade e que visem obter movimentos dentários em tempo adequado $^{29,87}$. Apesar disso, ainda que pouco explorada na literatura ${ }^{112,120}$, sabe-se que o risco de reabsorção dentária apical não é maior em dentes com rizogênese incompleta. Para ROSENBERG ${ }^{120}$, a presença da papila dentária seria um fator de proteção contra a reabsorção dentária apical quando da movimentação dentária induzida.

Com base nestes conhecimentos, a avaliação efetuada nos pacientes ao final da terapia com aparelhos removíveis, considerando-se a idade dos pacientes e a época de rizogênese para cada grupo de incisivos, refere-se à interrupção do seu processo de desenvolvimento, além do grau de reabsorção radicular ${ }^{56}$. De outro modo, a avaliação dos pacientes ao final do tratamento com aparelho fixo refere-se à quantidade de reabsorção radicular, pois todos os incisivos já possuiam as suas raízes formadas ao início do tratamento. Durante o evento biológico, é possível diferenciar morfologicamente a raiz em formação da raiz em reabsorção. Naquela, as bordas apicais são regulares, enquanto que nesta, durante a rizólise, nota-se acentuada irregularidade na superfície de reabsorção da raiz. Não obstante, em termos clínicos, pode-se afirmar que a comparação entre as duas situações é perfeitamente válida, pois ambos tiveram como conseqüência a perda de estrutura dentária.

De forma semelhante, não houve a preocupação em subdividir os grupos pelas características anatômicas ou formas geométricas das raízes dos incisivos $^{45,77}$. É de conhecimento que a morfologia da raiz dentária representa o principal fator na previsibilidade da ocorrência de reabsorções dentárias durante a movimentação dentária ${ }^{30,72,112,126}$. Apesar disso, a morfologia radicular não foi relevada. Não foi o questionamento principal do trabalho correlacionar os tipos de desvios radiculares com a magnitude das reabsorções dentárias ou do encurtamento radicular, mas sim verificar se existe diferença entre a quantidade de perda de estrutura dentária ocasionada pelo uso de dois diferentes aparelhos removíveis em comparação com um grupo controle. 
É de conhecimento que quando os dados de uma pesquisa podem ser adequadamente analisados por uma prova paramétrica, esta prova é a mais poderosa, ou seja, apresenta pequena probabilidade de rejeitar a hipótese nula quando esta é verdadeira, porém grande probabilidade de rejeitar a hipótese nula quando ela é falsa. Apesar de algumas pesquisas adotarem um nível de significância assaz restrito ${ }^{63,112}$, na presente investigação considerou-se um nível de significância de 0,05 , à semelhança de outros trabalhos ${ }^{21,22,77,80,81,87}$, e por ser valor comumente empregado em biologia ${ }^{28,130}$. Entretanto, sabe-se que o processo de se aderir rigidamente a um nível de significância tem sido rejeitado em favor dos processos de decisão em termos de funções de "perdas" ou "ganhos" em determinada pesquisa ${ }^{130}$. Dessa forma, para não correr o risco de recomendar uma técnica clínica em detrimento de outra, a quantidade de encurtamento radicular também foi considerada quanto ao seu significado clínico.

A forma de análise dos resultados foi expressa pela mediana. Segundo SIEGEL ${ }^{130}$, a estatística mais adequada para a descrição da tendência central dos valores de uma escala ordinal é a mediana, pois esta não é afetada por modificações de quaisquer valores abaixo ou acima dela. Se uma prova paramétrica se refere à diferença entre duas médias, seu equivalente nãoparamétrico poderá referir-se à diferença entre as medianas. Entretanto, a mediana, que corresponde ao valor que se localiza no centro da distribuição dos dados após sua ordenação, pode não retratar completamente as características de um grupo ${ }^{28}$. Freqüentemente, escores empatados podem ocorrer. Dessa forma, além dos valores da mediana, determinou-se a média aritmética, para auxiliar na comparação entre os grupos e subgrupos. Embora não forneça valores para os escores de reabsorção dentro das categorias estipuladas inicialmente ${ }^{77}(0,1,2,3$ ou 4), o cálculo da média possibilitou tornar o conjunto de dados da amostra mais representativo. O posto médio, medida comumente empregada para a descrição de mensurações ordinais de um grupo, é dependente dos valores dos outros grupos analisados em uma avaliação, e por isso não pode servir como parâmetro de comparação com outros resultados ${ }^{28}$. 
Para a avaliação do grau de reabsorção radicular apical, os incisivos superiores e inferiores foram os dentes de eleição. Inicialmente considerou-se a avaliação pelo número de pacientes, levando-se em conta o grau de reabsorção radicular dos oito incisivos, separadamente. Apesar de ser menos representativo estatisticamente, dessa forma tornou-se possível fornecer uma idéia mais precisa da diferença na quantidade de reabsorção entre os grupos e subgrupos. Em adição, com o propósito de facilitar a discussão dos resultados, determinou-se a média aritmética dos escores obtidos da avaliação dos incisivos (DM). Como citado anteriormente, a despeito desse procedimento não fornecer os valores estipulados para os escores ${ }^{77}$, dessa forma tornou-se possível fornecer uma melhor estimativa do grau de reabsorção radicular para o grupo analisado ${ }^{116}$.

Como avaliação complementar, os testes estatísticos foram aplicados às amostras considerando-se o grau de reabsorção radicular sem distinção do grupo de dentes ao qual pertence o incisivo, nem separação entre os lados direito e esquerdo. Considerou-se a avaliação pelo número de dentes. Assim, esse procedimento multiplicou o número de dentes da amostra por oito, aumentando o poder da prova estatística e facilitando a explicação dos resultados. A desvantagem para essa forma de avaliação encontra-se na impossibilidade de localizar em qual grupo de incisivos ocorreu maior quantidade de reabsorção. Em adição, os testes estatísticos aplicados no presente trabalho (testes de Kruskal-Wallis e Mann-Withney) são indicados para a comparação de amostras independentes. Alguns autores relatam que existe uma associação no padrão de reabsorção, ou seja, quando ocorre reabsorção em um dente, torna-se possível encontrá-la nos demais, porém, variando quanto ao grau de severidade ${ }^{17,25,149}$. Desse modo, pode existir influência dentro do mesmo indivíduo.

\subsection{0 erro intra-examinador}

Um teste de diagnóstico é preciso quando suas medições são consistentes. A precisão ou reprodutibilidade é avaliada ao compararmos os resultados de repetidos pareceres sobre o mesmo objeto; é a consistência de 
resultados quando a medição ou o exame se repete. Para que os resultados desse trabalho fossem confiáveis, procurou-se minimizar os erros dos métodos de mensuração empregados. As condições de exame foram padronizadas: o equipamento, o ambiente, as informações fornecidas e o período do dia (variáveis extrínsecas ao examinador), foram mantidos constantes em todas as etapas das consecutivas medições ${ }^{146}$.

O fato de o exame radiográfico ser o melhor método de análise entre os acessíveis empregado nas pesquisas sobre reabsorção radicular faz com que a avaliação do erro intra-examinador torne-se extremamente importante. A amostra foi reexaminada em 30 pacientes (34\% do seu total) e foi utilizado o coeficiente Kappa (к) ou Cohen's kappa para a obtenção dos valores de concordância $^{74}$. Este coeficiente verifica a quantidade de concordância entre os dados categóricos em duas avaliações distintas subtraindo deste valor o número de concordâncias que possam ter ocorrido por mero acaso.

No presente trabalho, a segunda medição apresentou um mínimo de porcentagem de concordância de $83,33 \%$ com a primeira medição, o que corresponde a um valor de coeficiente Kappa de 0,71 (Tabela 1). De acordo com LANDIS \& $\mathrm{KOCH}^{74}$ este valor é considerado de fidedignidade substancial em uma avaliação de concordância entre dados categóricos. Não obstante, na avaliação deste trabalho, as diferenças dos valores dos graus de reabsorção radicular nunca excederam a um escore.

LEVANDER; MALMGREN; STENBACK ${ }^{79}$, em 1998, com o objetivo de aumentar a precisão e a confiabilidade da metodologia de sua pesquisa, realizaram novamente a avaliação por postos em todas as radiografias da amostra. Os autores verificaram similaridade das avaliações em 156 das 186 radiografias analisadas, correspondente a 83,87\% de porcentagem de concordância, valor bastante próximo do encontrado na presente investigação.

Pelos resultados, foi verificada como substancial ou quase perfeita a fidedignidade das medições. Estes dados respaldam a variável examinador, sendo esta de baixa influência nos resultados obtidos; ou seja, há confiabilidade no exame. Os resultados foram consistentes quando a avaliação por escores se repetiu. 


\subsection{Os resultados}

\subsubsection{Quantidade de reabsorção}

Os resultados demonstraram que não houve uma diferença estatisticamente significante entre os graus de reabsorção radicular entre os grupos 1 e 2, embora, de modo geral, estes tenham apresentado diferença significante em relação ao grupo controle (Tabela 6). Na avaliação específica para cada tipo de incisivo, em nenhum momento ocorreu diferença estatisticamente significante entre os grupos experimentais. Observando-se a média dos escores obtidos da avaliação dos incisivos (DM), os valores da mediana apresentaram-se idênticos, e bastante próximos para os valores da média aritmética, demonstrando grande similaridade da quantidade de reabsorção ocasionada pelo uso dos dois tipos de aparelho.

Conforme descrito acima, embora não exista diferença estatisticamente significante entre os dois grupos experimentais quanto à quantidade de reabsorção, algumas considerações podem ser feitas com respeito ao protocolo de utilização dos dois aparelhos. Quando se observa a preconização do tempo de uso diário de cada aparelho, as suas diferenças devem ser destacadas. Segundo seu idealizador ${ }^{41}$, o aparelho de Fränkel deve ser utilizado em tempo integral pelo paciente, excetuando apenas o período das refeições. O Guia de Erupção, por sua vez, possui o tempo mínimo recomendado de uso do aparelho de 4 horas ativamente durante o dia e passivamente à noite, sendo que as quatro horas de uso diário devem ser divididas em quatro períodos de uma hora, não consecutivas. Sabe-se que as forças são freqüentemente interrompidas com o uso de aparelhos removíveis. Cada momento de remoção do aparelho corresponde a momentos de desativação dos mecanismos reabsortivos ${ }^{30}$. Este período de repouso propicia melhores condições para a resposta metabólica exigida pelo movimento dentário, permitindo melhor proliferação e atividade celular nos tecidos de suporte e criando condições mais favoráveis a uma nova resposta quando o aparelho for reativado. Além disso, os períodos de repouso permitem o reparo das cavidades reabsortivas dos dentes com cemento secundário. Acredita-se 
que o processo de reparo se inicia no momento da remoção da força ortodôntica ou quando ela é reduzida abaixo de um certo nível ${ }^{115,123}$. Dessa forma, embora se baseie em achados microscópicos e em fundamentos teóricos, deve-se observar com atenção a relação entre o tempo de uso diário do aparelho com a quantidade de reabsorção, na presente investigação.

Nesse sentido, outro fator a se considerar se refere ao grau de colaboração e aceitação dos pacientes com o uso dos dois tipos de aparelhos removíveis. Estes podem ser recomendados a serem utilizados por um número de horas prescrito, entretanto, o paciente pode não se mostrar colaborador com o tratamento. Em relação ao paciente não-colaborador, algumas vezes o tratamento é acompanhado por longos períodos de tempo, mas, no entanto, sem existir pressão sobre os dentes, e por esse motivo o tempo de tratamento algumas vezes pode não ser detectado como fator predisponente à reabsorção ${ }^{112}$. JANSON et al. $^{65}$, em 2003, avaliaram as respostas dos pacientes à utilização do aparelho de Fränkel e os aparelhos Guias de Erupção. Apesar de ser de natureza retrospectiva, sendo os dados angariados das fichas dos pacientes, muitos deles utilizados na presente investigação, esse estudo piloto já possibilitou demonstrar uma tendência da resposta dos pacientes. Na terapia com o aparelho de Fränkel, observou-se que apenas $13,1 \%$ dos pacientes apresentaram "boa colaboração" porque utilizaram o aparelho corretamente conforme o número de horas recomendadas, contrapondo-se aos $42,1 \%$ dos pacientes que utilizaram o aparelho Guia de Erupção. Deve-se ressaltar que o número de horas de uso preconizado é maior para o aparelho de Fränkel, e por isso necessita de maior compromisso do paciente com o tratamento. Evidentemente que respostas diferentes quanto à reabsorção radicular, devido aos diferentes graus de colaboração entre os grupos experimentais, podem ocorrer.

O tempo de tratamento aumentado para o grupo de pacientes tratados com os Guias de Erupção (Tabela 3), apesar de estatisticamente não exibir diferença, pode gerar questionamentos quanto à sua influência nos resultados. Entretanto, quando da comparação do grau de reabsorção entre os três grupos (Tabela 6), evidenciou-se maior perda de estrutura radicular para o grupo 1. Logo, ainda que apresentando um tempo de tratamento menor, o grupo de 
pacientes tratado com o aparelho de Fränkel exibiu maior quantidade de reabsorção. Sendo assim, essa variável parece não se relacionar com os resultados da presente investigação. O mesmo raciocínio se aplica para o período de uso dos aparelhos removíveis, entre os subgrupos 1.2 e 2.2 (Tabela 3). Embora apresente um tempo de tratamento estatisticamente reduzido, 0 subgrupo 1.2 exibiu maior reabsorção radicular (Tabela 8). De outra forma, em relação ao tempo de tratamento da fase de aparelhos fixos, bastante semelhante para ambos os subgrupos, este pode estar relacionado a muitas variáveis, como colaboração do paciente, habilidade do operador, grau de detalhamento oclusal final, e por isso seria arriscado correlacioná-lo diretamente com a extensão da movimentação dentária e, conseqüentemente, ao grau de reabsorção radicular.

Embora o grupo controle tenha sido composto de indivíduos que não receberam qualquer tipo de tratamento, o mesmo também apresentou reabsorção radicular apical, alcançando em alguns casos o escore 2 (reabsorção moderada). Como o critério para a seleção do grupo controle foi o mesmo aplicado aos grupos experimentais no exame radiográfico inicial, excluindo-se os vícios bucais ou o histórico de traumatismo dentário prévio, as reabsorções dentárias encontradas podem ser atribuídas ao uso normal dos dentes até este período de vida do indivíduo ${ }^{31}$ (Tabela 6). Dessa forma, para a análise da quantidade de reabsorção dos grupos de pacientes tratados deve-se considerar, também, a redução fisiológica de estrutura radicular.

O principal objetivo da pesquisa consistiu na comparação entre os pacientes que fizeram uso dos dois tipos de aparelhos removíveis, exclusivamente (Tabela 7), porque hipoteticamente nesta confrontação poderia se encontrar o fator diferencial para a escolha de uma ou outra forma de tratamento. Entre os subgrupos 1.1 e 2.1 verificou-se alta similaridade na quantidade de reabsorção radicular. Novamente, em momento algum houve diferença estatisticamente significante entre os subgrupos experimentais, na avaliação para cada tipo de incisivo. Fato interessante se encontra na ausência de diferença estatisticamente significante para a quantidade de reabsorção dos incisivos laterais superiores, entre os dois subgrupos experimentais e o grupo controle. Como descrito anteriormente, os incisivos laterais superiores são os 
últimos dentes na região anterior a ter a calcificação das raízes completadas $^{82,112}$. Dessa forma, esses dentes estariam menos sujeitos à reabsorção radicular apical por um período mais prolongado durante o uso do aparelho removível, até os 11 anos de idade. LINGE \& LINGE ${ }^{80}$ encontraram um aumento no comprimento radicular de $0,3 \mathrm{~mm}$ nos pacientes que iniciaram o tratamento antes dos 11 anos de idade, comparados com os 0,8mm esperados para os indivíduos não-tratados. Isso representa uma perda de $0,5 \mathrm{~mm}$ de comprimento radicular, em comparação com a perda de comprimento médio de 0,97mm nos pacientes que iniciaram o tratamento após os 11 anos de idade. Esta pode ser a explicação para a igualdade estatística em relação ao grupo controle.

Embora o resultado da comparação entre os subgrupos apresente poucas diferenças, algumas observações podem ser feitas em relação à menor reabsorção encontrada no subgrupo 1.1, observando-se os valores da média dos escores obtidos da avaliação dos incisivos (DM; Tabela 7). Neste estudo houve uma suave tendência de maior biocompatibilidade do subgrupo de pacientes tratados com o aparelho de Fränkel, exclusivamente. Em comparação com o grupo controle, o subgrupo dos pacientes tratados com o Regulador de Função não apresentou diferença estatística significante para todas as avaliações dos tipos de incisivos. Entre os dois subgrupos experimentais, o correspondente aos Guias de Erupção demonstrou maior grau de reabsorção radicular apical. Apesar de estatisticamente não existir diferenças, a explicação para a disparidade dos valores pode se encontrar em algumas diferenças no modo de ação dos dois tipos de aparelhos.

A reabsorção radicular se relaciona intimamente com a extensão do movimento ortodôntico induzido ${ }^{127}$. O Regulador de Função se diferencia da maioria de outros aparelhos ortopédicos funcionais por ser mucosuportado e, como permite um contato mínimo com os dentes, apresenta teoricamente menor efeito dentoalveolar ${ }^{44}$. Segundo seu inventor ${ }^{41}$, este aparelho não é um dispositivo de movimentação dentária e, por isto, sua aplicação é limitada e em muitas ocasiões deve ser utilizado em conjunto com aparelhos fixos ou removíveis $^{65}$. Entretanto, apesar das alegações de FRÄNKEL ${ }^{41,42}$ de que se todos os cuidados com a construção, adaptação e utilização do Regulador de 
Função forem tomados, não ocorre compensação dentoalveolar, a maioria dos trabalhos mostra o contrário ${ }^{50,92,98}$. McNAMARA Jr.; BOOKSTEIN; SHAUGHNESSY ${ }^{91}$ verificaram a ocorrência de movimento para posterior dos incisivos superiores de 2,3 a 2,7mm e uma inclinação para vestibular dos incisivos inferiores, de 0,5 a 1,2mm, sem influência na sua posição vertical. De maneira similar, JANSON et al. ${ }^{58}$, em 2003, avaliaram prospectivamente os efeitos do RF em 18 jovens brasileiros após dois anos de tratamento. Verificaram que os efeitos para a correção das más oclusões de Classe II foram principalmente dentoalveolares, com uma menor participação de alterações esqueléticas. Os autores observaram retrusão significante dos incisivos superiores $(1,93 \mathrm{~mm})$ e protrusão de menor magnitude dos incisivos inferiores $(0,27 \mathrm{~mm})$. Os autores verificaram que a correção da sobremordida profunda somente foi possível devido ao maior desenvolvimento vertical dos molares inferiores, de 2,04mm, considerado estatisticamente significante. Não houve restrição no desenvolvimento vertical dos incisivos. Isso pode ser explicado pela ausência de contato de qualquer componente do aparelho com as bordas incisais desses dentes. Esta é a razão porque McNAMARA Jr. ${ }^{90}$ recomenda o RF-2 nos casos de Classe II, divisão 1: a modificação do aparelho permite o controle da posição vertical dos incisivos superiores.

A aplicação de forças no sentido apical, particularmente as mecânicas de intrusão, são apontadas como grandes causadoras de reabsorção radicular $^{33,37,88,135}$. O aparelho Guia de Erupção constitui-se de um corpo de material borrachóide único que apresenta intercuspidações para os dentes superiores e inferiores, de canino a canino, em oclusão normal. A correção da sobremordida é obtida pela maior espessura do material borrachóide entre os incisivos e pelo espaço que permanece entre os dentes posteriores. A intenção é que o paciente, ao morder efetivamente no aparelho, aplique uma força na região anterior para restringir o desenvolvimento vertical desses dentes, ajudando a corrigir a sobremordida ${ }^{61}$. Observou-se ao final do tratamento que os efeitos decorrentes do aparelho Guia de Erupção são principalmente dentoalveolares ${ }^{64}$. Ocorreu uma lingualização e retrusão dos incisivos superiores, da ordem de 2,21mm, além de inibição do desenvolvimento vertical dos mesmos, conforme observado em dois estudos prévios com períodos de 
tratamento menores ${ }^{60,110}$. Os incisivos inferiores experimentaram protrusão de 1,25mm, conseqüência provável da força induzida pela protrusão mandibular, mas não sofreram alterações significantes no desenvolvimento vertical. A correção da sobremordida profunda foi possível pela participação conjunta da intrusão dos incisivos superiores, de $0,81 \mathrm{~mm}$, considerada estatisticamente significante, e do maior desenvolvimento vertical dos molares inferiores, na quantidade de $2,03 \mathrm{~mm}$.

Dessa forma, a diferença presente da quantidade de reabsorção ao final de tratamento entre o subgrupo 1.1 e o subgrupo 2.1 pode ser explicada principalmente na suposição de que a aplicação de forças no sentido vertical dos incisivos com o Guia de Erupção pode ter causado maior grau de reabsorção radicular. O protocolo de tratamento desse dispositivo se diferencia pela aplicação de forças intrusivas nos dentes anteriores. Como explicado anteriormente, durante a sua utilização, o paciente é recomendado a ocluir intensamente no aparelho, por um minuto, relaxando por trinta segundos, repetidamente, até completar meia hora. Na outra meia hora de uso deverá manter somente ligeira pressão no aparelho ${ }^{11,61}$. Devido ao seu modo de uso, uma das indicações dos Guias de Erupção é também o tratamento da sobremordida profunda. JANSON et al. ${ }^{60}$, com a intenção de avaliar os efeitos cefalométricos do Guia de Erupção Occlus-o-guide, selecionaram 30 pacientes que utilizaram o aparelho durante 10 meses. Da amostra total, vinte e sete pacientes possuíam má oclusão de Classe II, divisão 1 , enquanto que três casos se caracterizavam por apresentar má oclusão de Classe I com trespasse vertical aumentado. Verificaram a ocorrência de inibição do desenvolvimento vertical dos incisivos superiores estatisticamente significante.

Alguns estudos direcionados à movimentação dentária induzida, mas que relacionam hábitos parafuncionais, podem ajudar a explicar a forma de atuação da reabsorção radicular com aplicação de forças verticais. ODENRICK \& BRATISTRÖM ${ }^{100}$, em 1983, encontraram um índice de reabsorção radicular significantemente mais alto nos pacientes com hábito de onicofagia, previamente ao tratamento ortodôntico. HARRIS \& BUTLER ${ }^{52}$, em 1992, observaram que pessoas portadoras de bruxismo tendiam a mostrar 
dentes mais curtos, devido à compressão do ligamento periodontal resultante de uma carga oclusal excessiva. Os resultados não surpreenderam os autores visto que é de conhecimento que, em média, os bruxônomos típicos apresentam episódios de 58 segundos de apertamento dos dentes, gerando uma força substancial sobre estes ${ }^{27}$. ARNOLD ${ }^{7}$, em 1981, já havia relatado que pacientes com bruxismo severo podem, com o passar do tempo, apresentar desaparecimento da lâmina dura dentária, reabsorções radiculares e lesões periapicais ou periodontais.

Além de atuarem no sentido vertical, os Guias de Erupção são também capazes de proporcionar relativa melhora do mau posicionamento dentário, por apresentar intercuspidações para os dentes superiores e inferiores. Em trabalho retrospectivo, JANSON et al. $^{65}$ verificaram a necessidade de finalização do aparelho de Fränkel e o Guia de Erupção com a ortodontia corretiva. Do número de pacientes tratados com o Guia de Erupção, 28,2\% não necessitaram de aparelhos fixos, contra 6,6\% dos casos tratados com 0 aparelho de Fränkel, que não necessitaram de aparelho fixo para a correção e melhora dos detalhes finais. Segundo a literatura ${ }^{92,131}$, o aparelho de Fränkel, quando empregado em pacientes com uma pequena quantidade de apinhamento, não os motivam a utilizá-lo pois, algumas vezes, o resultado não é o desejado. Sendo assim, a quantidade de movimentação dos incisivos no grupo de pacientes tratados com os Guias de Erupção, exclusivamente, foi maior que quando tratado com o Fränkel. A correção da sobremordida profunda, de apinhamentos suaves e giroversões com os Guias de Erupção pode ter contribuído para a maior reabsorção radicular apical.

Na comparação entre os pacientes tratados com o aparelho de Fränkel e aqueles que receberam tratamento com os Guias de Erupção, e que depois finalizaram com aparelho fixo, novamente não se evidenciou diferença estatística para todos os tipos de incisivos, somente em comparação ao grupo controle (Tabela 8). No entanto, ao exame das médias aritméticas, de um modo geral os valores do subgrupo 1.2 foram mais elevados em relação aos valores do subgrupo 2.2. A observação dos valores da média dos escores obtidos da avaliação dos incisivos (DM) demonstra que o subgrupo 1.2 demonstrou um grau de reabsorção radicular suavemente aumentado em relação ao subgrupo 


\section{2 .}

A explicação para essa tendência pode se basear no fato de que, como teoricamente os pacientes tratados inicialmente com os Guias de Erupção possuíam menores correções a serem efetuadas após a primeira fase do tratamento e, portanto, necessitaram de menor quantidade de movimentação, durante a fase de nivelamento e alinhamento dentário o dispêndio para as estruturas radiculares foi menor ${ }^{65}$. De outra forma, os pacientes que se trataram com o Regulador de Função numa primeira fase, apesar de corrigido a relação ântero-posterior dos molares, ainda apresentavam certo grau de sobremordida profunda, apinhamentos e giroversões ao final da terapia com o aparelho funcional. Assim, posteriormente, na terapia com aparelhos fixos, houve a necessidade de maior movimentação dentária para o posicionamento detalhado dos dentes, individualmente.

Os resultados da avaliação dos incisivos laterais superiores exemplificam o exposto acima. Embora não sejam estatisticamente significantes, a observação dos valores da mediana revela que os incisivos do subgrupo 1.2 apresentaram maior quantidade de reabsorção radicular (Tabela 8). Como o Regulador de Função não está indicado para corrigir apinhamentos ou giroversões, a correção do mal posicionamento dos incisivos laterais ocorreu com os aparelhos fixos. Além disso, a correção da sobremordida profunda do sugrupo 2.2 foi possível pela inibição do desenvolvimento vertical dos incisivos superiores, durante o uso dos Guias de Erupção ${ }^{60,64}$. Para o subgrupo 1.2, o movimento de intrusão dos incisivos superiores para a correção do trespasse vertical se tornou possível somente por meio de aparelhos fixos, após o término da rizogênese, período passível de ocorrência de reabsorção radicular ${ }^{29}$. O recurso rotineiramente utilizado nas mecânicas de deslizamento é a acentuação da curva de Spee do arco superior e reversão do inferior, durante as fases de nivelamento e alinhamento dentário.

Como explicado anteriormente, dentes com ápice aberto seriam dentes menos susceptíveis à reabsorção ${ }^{120}$, porque provavelmente sua nutrição é melhor e a celularidade da área apical é maior ${ }^{80}$. Este é um argumento utilizado pelos que advogam o tratamento ortodôntico em duas fases. A abordagem precoce objetivando corrigir as relações maxilo-mandibulares, geralmente mais 
longa, estaria apoiadas em dentes pouco susceptíveis à reabsorção ${ }^{112,120}$. Após, na segunda fase do tratamento, como vantagem adicional, uma menor quantidade de movimento seria exigida das estruturas dentárias.

Com o propósito de verificar a influência dos aparelhos fixos no grau de reabsorção radicular causado pelo uso do aparelho de Fränkel, comparou-se o subgrupo 1.1 com o subgrupo 1.2 (Tabela 9). Para todos os tipos de incisivos o subgrupo 1.2 apresentou os valores das médias mais elevadas. A observação da média dos escores obtidos da avaliação dos incisivos (DM) demonstra a existência de diferença estatisticamente significante entre os dois subgrupos. Sem dúvida, as evidências revelam um índice maior de reabsorção dentária durante o uso de aparelhos fixos ${ }^{17,26,80,112,113}$.

A comparação entre os subgrupos 2.1 e 2.2 revela resultados semelhantes aos citados anteriormente (Tabela 10). Novamente, para todos os tipos de incisivos, os pacientes que finalizaram com aparelhos fixos apresentaram as médias suavemente aumentadas daqueles que utilizaram os Guias de Erupção, exclusivamente, apesar de somente para um tipo de incisivo (D22) o teste estatístico tenha acusado diferença. Na observação da média dos escores obtidos da avaliação dos incisivos (DM), o subgrupo dos Guias de Erupção, exclusivamente, apresentou diferença estatisticamente menor quando comparado com aqueles que finalizaram com aparelhos fixos.

Ao analisar as Tabelas 9 e 10 conjuntamente, o teste estatístico acusou diferença significante para uma maior quantidade de tipos de incisivos na primeira avaliação. Quando se analisam os níveis de significância (p), os valores apresentam-se suavemente menores para a comparação da Tabela 9. A diferença entre a quantidade de reabsorção entre o final de tratamento do subgrupo 1.1 e o subgrupo 1.2, para a média dos escores obtidos da avaliação dos incisivos (DM), foi maior que a diferença entre o final de tratamento dos subgrupos 2.1 e $2.2(0,57$ contra 0,19). Esses valores complementam o raciocínio anterior de que a correção do trespasse vertical exagerado e a quantidade de movimentação dos incisivos no grupo de pacientes tratados com o Guia de Erupção, exclusivamente, foi maior do que quando tratado com o Fränkel. A correção da sobremordida profunda, de apinhamentos suaves e giroversões com a utilização dos Guias de Erupção resultaram em 
encurtamento maior do dente quando comparado com o uso do Fränkel, exclusivamente. Após a finalização com aparelho fixo, ocorreu o oposto. Como teoricamente os pacientes tratados com os Guias de Erupção possuíam menos correções a serem efetuadas e, portanto, menor quantidade de movimentação, apresentaram menor reabsorção radicular após o uso dos aparelhos fixos. Já os pacientes que utilizaram o Fränkel previamente, exibiram maior reabsorção ao final da terapia com aparelhos fixos.

Após os resultados das comparações isoladas pelo tipo de incisivo, considerando-se o número de pacientes das amostras, optou-se por analisar, como avaliação complementar, os graus de reabsorção encontrados pelo número de dentes analisados, sem a discriminação pelo tipo de incisivo, com o objetivo de aumentar o tamanho da amostra conseqüentemente a representatividade dos resultados, e de também facilitar a interpretação dos resultados (Tabelas 11 a 15).

Confirmaram-se, então, os resultados encontrados anteriormente. $\mathrm{Na}$ comparação entre os três grupos, levando-se em consideração a amostra total (Tabela 11), os pacientes que fizeram uso de aparelho removível, exclusivamente (Tabela 12), e os pacientes que necessitaram de aparelhos fixos (Tabela 13), o grau de reabsorção radicular não apresentou diferença estatisticamente significante entre os grupos e subgrupos experimentais. A diferença estatística somente foi encontrada em comparação ao grupo controle.

Da mesma forma, as Tabelas 14 e 15, que comparam os pacientes que fizeram uso de aparelhos removíveis, exclusivamente, daqueles que finalizaram com aparelhos fixos, porém, sem a diferenciação quanto ao tipo de incisivo, corroboram os resultados anteriores. Apesar dos valores das medianas serem iguais, a diferença das médias aritméticas entre os subgrupos 1.2 e $1.1(0,65)$ foi maior que a diferença entre os subgrupos 2.1 e $2.2(0,32)$.

Com essa avaliação complementar, pode-se afirmar, categoricamente, a paridade do grau de reabsorção radicular entre os dois tipos de aparelhos removíveis. 


\subsubsection{Prevalência de reabsorção}

Em comparação com os aparelhos fixos, a literatura atribui menos freqüência de reabsorção radicular ocasionada pelo uso dos aparelhos removíveis ${ }^{2,17,80,115}$.

SHARPE; REED; SUBTELNY129, em 1987, calculou o número de raízes reabsorvidas / número de raízes analisadas em pacientes que utilizaram aparelhos fixos. Os autores encontraram prevalência de 52,7\% para os incisivos centrais superiores e $45,7 \%$ para os incisivos centrais inferiores, valores bastante superiores aos verificados no presente trabalho (Tabela 16).

JANSON et al. ${ }^{63}$, em 2000, ao comparar três técnicas ortodônticas fixas utilizando a mesma metodologia da presente investigação, verificaram que, do total de dentes examinados, somente 2,25\% não apresentaram comprometimento radicular visível radiograficamente (grau 0). AHLGREN ${ }^{2}$ encontrou reabsorção em $100 \%$ dos pacientes tratados com aparelhos fixos, embora em nenhum caso tenha excedido um terço do comprimento radicular. Os autores não verificaram a ocorrência de reabsorção nos casos tratados com aparelhos removíveis. Na presente investigação, considerando-se os dois grupos experimentais conjuntamente, para um total de 512 dentes examinados, 393 apresentaram algum grau de reabsorção. Dessa forma, 23,24\% dos dentes analisados não exibiram indício de comprometimento radicular, valores concordantes com pesquisas previamente publicadas ${ }^{80,112}$. Não foram encontradas raízes com reabsorção de grau extremo (escore 4).

Entre os arcos dentários, constatou-se uma maior freqüência de reabsorção nos dentes do arco superior, corroborando com as pesquisas de JANSON et al. ${ }^{63}$, QUINTELLA ${ }^{112}$, BLAKE; WOODSIDE; PHAROAH $^{16}$ e GOLDSON $^{48}$. SAMESHIMA \& SINCLAIR ${ }^{125}$, em 2001, ao avaliar os registros de 868 pacientes, verificaram que os dentes superiores foram os mais severamente afetados aproximadamente pelo dobro. Entretanto, esses resultados discordam das conclusões de MASSLER \& MALONE ${ }^{85}$ que não encontraram diferenças significantes entre o número de dentes afetados, interarcos. 
Considerando-se os grupos de incisivos, a literatura relata conformidade com os resultados da prevalência de reabsorção ${ }^{2,25,26,97,112}$. Os pacientes tratados com o Regulador de Função manifestaram algum grau de reabsorção na seguinte ordem decrescente: incisivo central superior, incisivo lateral superior, incisivo central inferior e incisivo lateral inferior. Para o grupo tratado com os Guias de Erupção, houve resultados semelhantes: incisivo central superior, incisivo lateral superior e central inferior, e, por último, incisivo lateral inferior. Esses resultados, em concordância com outros estudos, demonstram precisão na metodologia empregada neste trabalho.

Ainda na observação da Tabela 16, comparando-se os dois tipos de aparelhos, o grupo 2 exibiu mais reabsorção que o grupo 1 nos quatro grupos de incisivos analisados. Tira-se por conseqüência, portanto, que o grupo de pacientes tratados com os Guias de Erupção, seguido ou não de aparelhos fixos, apresentaram maior prevalência de reabsorção radicular, de graus leve a moderado (escalas 1 e 2). Entretanto, quando se examina a prevalência de reabsorção de grau acentuado (escala 3; Tabela 17), que denota maior preocupação clínica, se observa que o grupo 1 foi o único que apresentou tal condição. Este fato, associado à diferença encontrada entre os grupos 1 e 2, levantou questionamentos à respeito da origem do desacordo entre as duas formas de tratamento: se foi causada pelo uso dos aparelhos removíveis, ou se pela finalização com aparelhos fixos. Dessa forma, após a avaliação da prevalência de reabsorção radicular nos três grupos, optou-se por analisar, separadamente, a prevalência de reabsorção encontrados nos subgrupos.

$\mathrm{Na}$ análise de reabsorção leve à moderada, a comparação entre os subgrupos 1.1 e 2.1 evidencia que o grupo de pacientes tratados com os Guias de Erupção, exclusivamente, realmente apresentaram valores maiores que o grupo tratado com o aparelho de Fränkel (Tabela 18). A explicação para a maior prevalência promovida pelos Guias de Erupção pode se encontrar na forma de atuação do aparelho, conforme esclarecido no tópico anterior.

A igualdade dos valores para o grupo dos incisivos centrais inferiores e a sua ausência para o grupo dos incisivos centrais superiores pode ser explicada, ao menos parcialmente, pelos resultados do tratamento obtidos com os dois tipos de aparelho (Tabela 18). JANSON et al. ${ }^{58}$, em 2003 , utilizando 
pacientes da amostra da presente investigação, verificou que o aparelho de Fränkel não restringiu o desenvolvimento vertical dos incisivos superiores e inferiores. Isto pôde ser explicado pela ausência de contato de qualquer parte do aparelho sobre as bordas incisais desses dentes. O mesmo autor ${ }^{64}$, em 2000, também analisando pacientes que fazem parte do presente trabalho, de modo semelhante verificou ausência de restrição ao desenvolvimento vertical dos incisivos inferiores. Contudo, os incisivos centrais superiores demonstraram inibição ao desenvolvimento vertical estatisticamente significante. Essa maior restrição aos incisivos centrais superiores promovido pelos Guias de Erupção pode ter contribuído para a maior prevalência de reabsorção neste subgrupo.

Após a distinção entre os pacientes que foram tratados com o Regulador de Função, exclusivamente, e aqueles que complementaram o tratamento com ortodontia fixa, foi possível identificar a que subgrupo pertencia os incisivos que apresentaram maior severidade de reabsorção radicular (Tabela 19). Verificouse reabsorção acentuada somente no subgrupo 1.2, correspondente a dois pacientes. Novamente, esses dados tendem a confirmar a assertiva de que os aparelhos fixos causam mais danos às estruturas radiculares ${ }^{80,115}$, embora não seja possível comprovar se a reabsorção foi originada na primeira ou na segunda fase do tratamento. Embora sejam situações isoladas, por se tratar de casos com reabsorção de grau acentuado, não podem ser considerados irrelevantes. A reabsorção severa, definida como a perda de mais de um quarto do comprimento radicular $^{129}$, se transforma em situação difícil para o ortodontista, entretanto, mesmo nesses pacientes, é difícil demonstrar maiores efeitos adversos ${ }^{66}$. O fenômeno da reabsorção radicular apical, apesar de bastante freqüente ao final do tratamento ortodôntico, raramente acarreta conseqüências clínicas significantes.

PHILLIPS $^{109}$ acredita que a quantidade de reabsorção radicular, na maioria das situações, é clinicamente insignificante, e não coloca em risco a vida ou função da dentadura. Entretanto, quando o prognóstico em longo prazo para as dentaduras com dentes reabsorvidos é analisado, deve-se considerar que os dentes com proporção coroa/raiz desfavorável reduziria dramaticamente as chances de sucesso. Os pacientes que apresentam reabsorção radicular 
com maior preocupação clínica são também vistos na literatura como casos distintos $25,63,66,77,116,119,126$.

$\mathrm{Na}$ edição de setembro de 1996 da revista American Journal of Orthodontics and Dentofacial Orthopedics, devotada exclusivamente aos efeitos iatrogênicos provenientes do tratamento ortodôntico, como a recidiva, redução da crista óssea alveolar, reabsorção radicular, recessão gengival, e acidentes ocorridos durante o manejo clínico do paciente, e que nem sempre terminam de forma esperada, BEHRENTS ${ }^{10}$ já escreveu que: "os insucessos são lembranças sensatas das imperfeições de nosso conhecimento e de que o avanço ainda se faz necessário". 


\subsection{Implicações clínicas}

Os resultados obtidos demonstram uma igual quantidade de reabsorção radicular apical entre os dois tipos de aparelhos investigados, independentemente do tempo de tratamento. Portanto, chega-se à conclusão de que os efeitos deletérios sobre as estruturas radiculares promovidos pelos Guias de Erupção e o aparelho de Fränkel são semelhantes. A comparação da eficácia entre os dois tipos de aparelhos, em investigação previamente realizada ${ }^{59}$, já demonstrou não apresentar diferenças. Dessa forma, os riscos iatrogênicos para as estruturas radiculares e os benefícios oclusais obtidos com o tratamento não podem servir como parâmetros para a escolha entre eles. Pode-se dizer que os aspectos a se considerar na seleção entre um dos dois tipos de aparelhos passam a ser essencialmente clínicos. O aparelho de Fränkel, pelo volume maior, causa um desconforto inicial para o paciente, além de necessitar de maior experiência do clínico com a sua manipulação, durante a moldagem, construção e instalação do aparelho. A necessidade de uso diário do aparelho é maior, e por isso solicita maior colaboração do paciente. Em contrapartida, os Guias de Erupção apresentam volume menor e requer menor número de horas diárias de utilização. A aceitação dos pacientes na sua utilização mostrou-se mais satisfatória, mas, quando se considera o tempo total de tratamento, para os casos avaliados, foi mais longo para os Guias de Erupção ${ }^{59,65}$. O aparelho de Fränkel possui a desvantagem de maior necessidade de refinamento oclusal com aparelhos fixos e, dessa forma, o risco de desenvolver reabsorções radiculares severas, embora pequeno, possui importância. Caberá ao clínico, juntamente com o paciente e seus responsáveis, decidir o tratamento mais vantajoso à sua condição. 


\subsection{Sugestões para pesquisas futuras}

Apesar dos estudos prévios ${ }^{59,58,60,64,65}$ terem sido projetados e conduzidos rigorosamente, os seus resultados, como todos os trabalhos científicos $^{73}$, nem sempre são universalmente aceitos. Isso porque foram realizados por mais de um operador, e os pacientes foram selecionados por um sistema de triagem ${ }^{99}$. Conseqüentemente, essas investigações avaliaram a eficácia do tratamento, que pode ser definida como "o fornecimento de cuidados sob condições ideais"75. Como resultado, embora se encontrem em periódicos de reconhecida sustentação científica, os seus resultados podem ser questionados quanto à prática na clínica ortodôntica. Este problema poderia ser solucionado pela condução de investigações que avaliassem a efetividade do tratamento, que seria "o fornecimento de cuidados sob condições mais relevantes quanto ao ambiente ao qual os cuidados propostos são fornecidos rotineiramente"75. Uma forma de contribuição seria comparar os grupos prospectivamente quanto ao grau de colaboração dos pacientes com o uso de aparelhos removíveis. 
CONCLUSÕES 


\section{CONCLUSÕES}

Após a avaliação dos resultados obtidos neste trabalho e de acordo com a metodologia empregada para a avaliação do grau de reabsorção radicular decorrente do tratamento com o Regulador Funcional de Fränkel e o aparelho Guia de Erupção, julga-se lícito concluir que:

1. os grupos e subgrupos experimentais apresentaram uma reabsorção radicular estatisticamente maior que o grupo controle. Entretanto, o grau de reabsorção foi suave, sem comprometimento clínico;

2. o grau de reabsorção radicular foi semelhante entre os grupos e subgrupos experimentais;

3. os dentes que apresentaram maior prevalência de reabsorção foram, em ordem decrescente: incisivos centrais superiores, incisivos laterais superiores, incisivos centrais inferiores e, por último, os incisivos laterais inferiores. 
REFERÊNCIAS BIBLIOGRÁFICAS 


\section{REFERÊNCIAS BIBLIOGRÁFICAS ${ }^{a}$}

1. ACAR, A. et al. Continuous vs. discontinuous force application and root resorption. Angle Orthod, v.69, n.2, p.159-64, Apr. 1999.

2. AHLGREN, J. A ten-year evaluation of the quality of orthodontic treatment. Swed Dent J, v.17, n.5, p.201-9, 1993.

3. ALEXANDER, S. A. Levels of root resorption associated with continuous arch sectional arch mechanics. Am J Orthod Dentofac Orthop, v.110, n.3, p.321-4, Sep. 1996.

4. AL-QAWASMI, R. A. et al. Genetic predisposition to external apical root resorption. Am J Orthod Dentofac Orthop, v.123, n.3, p.242-52, Mar. 2003.

5. ALVARES, L. C.; TAVANO, D. A. A imagem radiográfica. In: ALVARES, L.; TAVANO, D. Curso de radiologia em odontologia. 2.ed. São Paulo, Ed. Santos, 1990. p.17-36.

6. ARNESEN, F. A. Avaliação da reabsorção radicular externa, consecutiva ao tratamento ortodôntico. Piracicaba, 1984. 1984p. Dissertação (Mestrado) - Faculdade de Odontologia de Piracicaba, Universidade Estadual de Campinas.

7. ARNOLD, B. Bruxism and occlusion. Dent Clin Norh Am, v.35, n.3, p.395407, July 1981.

8. BAUMRIND, S.; KORN, E. L.; BOYD, R. L. Apical root resorption in orthodontic treated adults. Am J Orthod Dentofac Orthop, v.110, n.3, p.311-20, Sep. 1996.

\footnotetext{
${ }^{a}$ Normas recomendadas para uso no âmbito da Universidade de São Paulo, com base no documento "Referências Bibliográficas: exemplos", emanado do Conselho Supervisor do Sistema Integrado de Bibliotecas, em reunião de 20 de setembro de 1990.
} 
9. BECK, B. W.; HARRIS, E. F. Apical root resorption in orthodontically treated subjects: analysis of edgewises and light wire mechanics. Am J Orthod Dentofac Orthop, v.105, n.4, p.350-61, Apr. 1994.

10. BEHRENTS, R. G. Iatrogenics in orthodontics. Am J Orthod Dentofac Orthop, v.110, n.3, p.1-7, Sep. 1996.

11. BERGERSEN, E. O. The eruption myofunctional appliance: how it works, how to use it. Funct Orthod, v.1, n.3, p.28-35, Sep./Oct. 1984.

12. BERGERSEN, E. O. The eruption guidance myofuncional appliance: case selection, timing, motivation, indications and contraindications. Funct Orthod, v.2, n.1, p.17-33, Jan./Feb. 1985.

13. BERGERSEN, E. O. The eruption guidance myofunctional appliance in the consecutive treatment of malocclusion. J Acad Gen Dent, v.34, n.1, p.24-9, Jan./Feb. 1986.

14. BERGERSEN, E. O. Preventive and interceptive orthodontics in the mixed dentition with the myofuncion eruption guidance appliance: correction of overbite and overjet. J Pedod, v.12, n.3, p.292-324, Sum. 1988.

15. BISHARA, S. E.; ZIAJA, R. R. Functional appliances: a review. Am J Orthod Dentofac Orthop, v.95, n.3, p.250-8, Mar. 1989.

16. BLAKE, M.; WOODSIDE, D. G.; PHAROAH, M. J. A radiographic comparation of apical root resorption after orthodontic treatment with the edgewise and Speed appliances. Am J Orthod Dentofac Orthop, v.108, n.1, p.76-84, July 1995.

17. BREZNIAK, N.; WASSERTSTEIN, A. Root resorption after orthodontic treatment: part 2. Literature review. Am J Orthod Dentofac Orthop, v.103, n.2, p.138-46, Feb. 1993. 
18. BREZNIAK, N.; WASSERTSTEIN, A. Root resorption after orthodontic treatment: part 1. Literature review. Am J Orthod Dentofac Orthop, v.103, n.1, p.62-6, Jan. 1993.

19. BREZNIAK, N.; WASSERSTEIN, A. Orthodontically induced inflammatory root resorption. Part I: the basic science aspects. Angle Orthod, v.72, n.2, p.175-9, Apr. 2002.

20. BREZNIAK, N.; WASSERSTEIN, A. Orthodontically induced inflammatory root resorption. Part II: the clinical aspects. Angle Orthod, v.72, n.2, p.180-4, Apr. 2002.

21. BRIN, I. et al. The influence of orthodontic treatment on previously traumatized permanent incisors. Eur J Orthod, v.13, n.5, p.372-7, Oct. 1991.

22. BRIN, I. et al. External apical root resorption in Class II malocclusion: a retrospective review of 1 - versus 2-phase treatment. Am J Orthod Dentofac Orthop, v.124, n.2, p.151-6, Aug. 2003.

23. BROWN, R. J. The Fränkel appliance: indication for use and explanation of function. Int J Orofacial Myology, v.8, n.3, p.4-10, Nov. 1982.

24. BRUDVIK, P.; RYGH, P. The repair of orthodontic root resorption: an ultrastructural study. Eur J Orthod, v.17, n.3, p.189-98, June 1995.

25. CANSANÇÃO, J. M. Avaliação radiográfica da reabsorção radicular, consecutiva ao tratamento ortodôntico, pela técnica do arco de canto, relacionada com o sexo, a idade, a duração do tratamento, o período de uso do arco retangular e do aparelho extrabucal. Bauru, 1980. 68p. Dissertação (Mestrado) - Faculdade de Odontologia de Bauru, Universidade de São Paulo. 
26. CANTO, G. L. Estudo comparativo da reabsorção radicular apical, decorrente do tratamento ortodôntico, em pacientes tratados com a técnica do arco de canto simplificada, do arco reto e com a terapia bioeficiente. Bauru, 1997. 162p. Dissertação (Mestrado) - Faculdade de Odontologia de Bauru, Universidade de São Paulo.

27. CLARKE, N. G.; TOWNSEND, G. C.; CAREY, S. E. Bruxism patterns in man during sleep. J Oral Rehabil, v.11, p.198-208, 1979.

28. CONOVER, W. J. Practical non parametric estatistic. New York, John Wiley and Suns, 1991.

29. CONSOLARO, A.; MARTINS-ORTIZ, M. F.; VELLOSO, T. R. G. Dentes com rizogênese incompleta e movimento ortodôntico: bases biológicas. Rev Dental Press Ortodon Ortop Facial, v.6, n.2, p.25-30, mar./abr. 2001.

30. CONSOLARO, A. Reabsorções dentárias nas especialidades clínicas. Maringá, Dental Press, 2002.

31. CONSOLARO, A. Sobre alguns aspectos metodológicos de pesquisas em movimentação dentária induzida e das reabsorções dentárias: uma proposta de guia e cuidados para análise de trabalhos. Rev Dental Press Ortodon Ortop Facial, v.9, n.2, p.104-9, mar./abr. 2004.

32. COPELAND, S.; GREEN, L. J. Root resorption in maxillary central incisors following active orthodontic treatment. Am J Orthod, v.89, n.1, p.51-5, Jan. 1986.

33. COSTOPOULOS, G.; NANDA, R. An evaluation of root resorption incident to orthodontic intrusion. Am J Orthod Dentofac Orthop, v.109, n.5, p.543-8, May 1996. 
34. COURTNEY, M.; HARKNESS, M.; HERBISON, P. Maxillary and cranial base changes during treatment with functional appliances. Am J Orthod Dentofac Orthop, v.109, n.6, p.616-24, Jun. 1996.

35. CREEKMORE, T. D.; RADNEY, L. J. Fränkel appliance: orthopedic or orthodontic? Am J Orthod, v.83, n.2, p.89-108, Feb. 1983.

36. CUOGHI, O. A. Avaliação macro e microscópica dos primeiros momentos da movimentação dentária induzida em macacos da espécie Cebus apella. Bauru, 1995. 138p. Tese (Doutorado) Faculdade de Odontologia de Bauru, Universidade de São Paulo.

37. DERMAUT, L. R.; DE MUNCK, A. Apical root resorption of upper incisors caused by intrusive tooth movement: a radiographic study. Am J Orthod Dentofac Orthop, v.90, n.4, p.321-6, Oct. 1986.

38. DESHIELDS, R. W. A study of root resorption in the treated Class II, division 1 malocclusion. Angle Orthod, v.39, n.4, p.231-45, Oct. 1969.

39. DOUGHERTY, H. I. The effect of mechanical forces upon the mandibular bucal segments during orthodontic treatment. Part I. Am J Orthod, v.54, n.1, p.29-49, Jan. 1968.

40. FRÄNKEL, R. The theoretical concept underlying the treatment with funcional correctors. Eur Orthod Soc Trans, v.42, p.233-54, 1966.

41. FRÄNKEL, R. The treatment of Class II, div. 1 malocclusion with funcional correctors. Am J Orthod, v.55, n.3, p.265-75, Mar. 1969.

42. FRÄNKEL, R.; REISS, W. Sur problematk der unterkiefernachentwicklung bei distalbissfallen. Fortschr Kieferorthop, v.31, p.345-55, 1970. 
43. FRÄNKEL, R. Concerning recent articles on Fränkel appliance therapy (a letter). Am J Orthod, v.85, p.442-4, 1984.

44. FRÄNKEL, R.; FRÄNKEL, C. Ortopedia orofacial com o regulador de função. São Paulo, Ed. Santos, 1990.

45. FURQUIM, L. Z. Perfil endocrinológico de pacientes ortodônticos com e sem reabsorções dentárias: correlação com a morfologia radicular e da crista óssea alveolar. Bauru, 2002. 123p. Tese (Doutorado) - Faculdade de Odontologia de Bauru, Universidade de São Paulo.

46. GHAFARI, J. et al. Headgear versus function regulator in the early treatment of Class II, division 1 malocclusion: a randomized clinical trial. Am J Orthod Dentofac Orthop, v.113, n.1, p.51-61, Jan. 1998.

47. GOLDIN, B. Labial root torque: effect on the maxilla and incisor root apex. Am J Orthod Dentofac Orthop, v.95, n.3, p.208-19, Mar. 1989.

48. GOLDSON, R.; HENRIKSON, C. O. Root resorption during Begg treatment: a longitudinal roentgenologic study. Am J Orthod, v.68, n.1, p.55-66, July 1975.

49. GRABER, T. M.; NEUMANN, B. Aparelhos ortodônticos removíveis. $2^{a}$.ed. São Paulo, Médica Panamericana, 1987.

50. HAMILTON, S. D.; SINCLAIR, P. M.; HAMILTON, R. H. A cephalometric, tomographic, and dental cast evaluation of the Fränkel therapy. Am $\mathbf{J}$ Orthod Dentofac Orthop, v.92, n.4, p.427-36, Nov. 1987.

51. HARRIS, E. F.; BAKER, W. C. Loss of root length and crestal bone height before and during treatment in adolescent and adult orthodontic patients. Am J Orthod, v.98, n.5, p.463-9, Nov. 1990. 
52. HARRIS, E. F.; BUTLER, M. L. Patterns of incisor root resorption before and after orthodontic correction in cases with anterior open bites. Am J Orthod Dentofac Orthop, v.101, n.2, p.112-9, Feb. 1992.

53. HARRIS, E. F.; KINERET, S. E.; TOLLEY, E. A. A heritable component for external apical root resorption in patients treated orthodontically. Am J Orthod Dentofac Orthop, v.111, n.3, p.301-9, Mar. 1997.

54. HARRIS, E. F. Root resorption during orthodontic therapy. Semin Orthod, v.6, p.183-94, 2000.

55. HEMLEY, S. The incidence of root resorption of vital permanent teeth. $\mathbf{J}$ Dent Res, v.20, p.133-41, 1941.

56. HENDRIX, I. et al. A radiographic study of posterior apical root resorption in orthodontic patients. Am J Orthod, v.105, n.4, p.345-9, Apr. 1994.

57. HIRZEL, H.; GREWE, J. M. Activators: a practical approach. Am J Orthod, v.66, n.5, p.557-70, Nov. 1974.

58. JANSON, G. et al. Class II treatment effects of the Fränkel appliance. Eur $\mathbf{J}$ Orthod, v.25, n.3, p.301-9, Jun. 2003.

59. JANSON, G. et al. Occlusal changes of Class II malocclusion treatment between Fränkel and the eruption guidance appliance. Angle Orthod, v.74, n.4, p.521-5, Apr. 2004.

60. JANSON, G. R. P. et al. Cephalometric evaluation of the eruption guidance appliance in Class II, division 1 treatment. J Clin Orthod, v.31, n.5, p.299-306, May 1997. 
61. JANSON, G. R. P. et al. Correção da sobremordida com o aparelho guia de erupção: apresentação de dois casos clínicos. Rev Dental Press Ortodon Ortop Facial, v.3, n.1, p.32-46, jan./fev. 1998.

62. JANSON, G. R. P. Influência do padrão facial no tratamento ortodôntico da Classe III. In: SAKAI, E.et al. Nova visão em ortodontia-ortopedia facial. São Paulo, Ed. Santos, 2000. p.371-8.

63. JANSON, G. R. P. et al. A radiographic comparison of apical root resorption after orthodontic treatment with 3 different fixed appliance techniques. Am J Orthod Dentofac Orthop, v.118, n.3, p.262-73, Sep. 1999.

64. JANSON, G. R. P. et al. Eruption guidance appliance effects in the treatment of Class II, division 1 malocclusions. Am J Orthod Dentofac Orthop, v.117, n.2, p.119-29, Feb. 2000.

65. JANSON, G. R. P. et al. Avaliação do grau de colaboração e aceitação dos pacientes na utilização de dois diferentes tipos de aparelhos removíveis. Rev Dental Press Ortodon Ortop Facial, v.8, n.2, p.31-40, mar./abr. 2003.

66. KALEY, J.; PHILLIPS, C. Factors related to root resorption in edgewise practice. Angle Orthod, v.61, n.2, p.125-32, Sum. 1991.

67. KALKWARF, K. L.; KREJCI, R. F.; PAO, Y. C. Effect of apical root resorption on periodontal support. J Prosth Dent, v.56, n.3, p.317-9, Sep. 1986.

68. KESLING, H. D. The tooth positioner as the means of final positioning of teeth to a predetermining pattern. J Dent Child, v.11, n.4, p.103-5, Oct. 1944. 
69. KESLING, H. D. The philosophy of the tooth positioning appliance. Am J Orthod, v.31, n.6, p.297-304, June 1945.

70. KETCHAM, A. H. A preliminary report of investigation of apical root resorption of permanent teeth. Int J Orthod Oral Surg Radiog, v.18, n.2, p.97-127, Feb. 1927.

71. KILLIANY, D. M. Root resorption caused by orthodontic treatment: an evidence-based review of literature. Semin Orthod, v.5, p.128-33, 1999.

72. KJAER, I. Morphological characteristics of dentitions developing excessive root resorption during orthodontic treatment. Eur J Orthod, v.17, n.1, p.25-34, Feb. 1995.

73. KROGMAN, W. M. Craniometry and cephalometry as research tools in growth of head and face. Am J Orthod, v.37, p.406-14, June 1951.

74. LANDIS, J. R.; KOCH, G. G. The measurement of observer agreement for categorical data. Biometrics, v.33, n.1, p.159-74, Mar. 1977.

75. LAST, J. H. A dictionary of epidemiology. New York, Oxford University Press, 1995.

76. LEE, R. T. The Fränkel appliance. Dent Update, v.2, n.4, p.239-40, 1984.

77. LEVANDER, E.; MALMGREN, O. Evaluation of the risk of root resorption during orthodontic treatment: a study of upper incisors. Eur J Orthod, v.10, n.1, p.30-8, Feb. 1988.

78. LEVANDER, E.; BAIJKA, R.; MALMGREN, O. Early radiographic diagnosis of apical root resorption during orthodontic treatment: a study of maxillary incisors. Eur J Orthod, v.20, n.1, p.57-63, Feb. 1998. 
79. LEVANDER, E.; MALMGREN, O.; STENBACK, K. Apical root resoption during orthodontic treatment of patients with multiple aplasia: a study of maxillary incisors. Eur J Orthod, v.20, n.4, p.427-34, Aug. 1998.

80. LINGE, B. O.; LINGE, L. Apical root resorption in upper anterior teeth. Eur J Orthod, v.5, n.3, p.173-83, Aug. 1983.

81. LINGE, L.; LINGE, B. O. Patients characteristics and treatment variables associated with apical root resorption during orthodontic treatment. Am J Orthod Dentofac Orthop, v.99, n.1, p.35-43, Jan. 1991.

82. LOGAN, W. H. G.; KRONFELD, R. Development of the human jaws and surrounding structures from birth to the age of fifteen years. J Am Dent Ass, v.20, n.3, p.372-427, Mar. 1933.

83. MALMGREN, O. et al. Root resorption after orthodontic treatment of traumatized teeth. Am J Orthod Dentofac Orthop, v.82, n.6, p.487-91, Dec. 1982.

84. MARTINS, D. R.; CANSANÇÃO, J. M.; SANCHEZ, J. F. Avaliação radiográfica da reabsorção radicular consecutiva ao tratamento ortodôntico. Ortodontia, v.27, n.3, p.4-8, set./dez. 1994.

85. MASSLER, M.; MALONE, A. J. Root resorption in human permanent teeth: a roentgenographic study. Am J Orthod, v.40, n.8, p.619-33, Aug. 1954.

86. MAVRAGANI, M. et al. A radiographic comparison of apical root resorption after orthodontic treatment with a standard edgewise and a straight-wire edgewise technique. Eur J Orthod, v.22, n.6, p.665-74, Dec. 2000.

87. MAVRAGANI, M. et al. Changes in root length during orthodontic treatment: advantages for immature teeth. Eur J Orthod, v.24, n.1, p.91-7, Feb. 2002. 
88. MCFADEN, W. M. et al. A study of the relationship between incisor intrusion and root shortening. Am J Orthod Dentofac Orthop, v.96, n.5, p.390-6, Nov. 1989.

89. MCNAMARA JR, J. A. The Fränkel appliance. I. Biological basis and appliance design. J Clin Orthod, v.16, n.5, p.320-37, May 1982.

90. MCNAMARA JR, J. A. The Fränkel appliance. II. Clinical management. J Clin Orthod, v.16, n.6, p.390-407, Jun. 1982.

91. MCNAMARA JR, J. A.; BOOKSTEIN, F. L.; SHAUGHNESSY, T. G. Skeletal and dental changes following functional regulator therapy on Class II patients. Am J Orthod, v.88, n.2, p.91-110, Aug. 1985.

92. MCNAMARA JR, J. A.; HOWE, R. P.; DISCHINGER, T. G. A comparison of the Herbst and Fränkel appliances in the treatment of Class II malocclusions. Am J Orthod Dentofac Orthop, v.98, n.2, p.134-44, Aug. 1990.

93. METHENITOU, S. et al. The prevention of overbite and overjet development in the 3 to 8 years old by Nighttime Guidance of incisal eruption: a study of 43 individuals. J Pedod, v.14, n.4, p.218-30, Sum. 1990.

94. MIRABELLA, A. D.; ARTUN, J. Prevalence and severity of apical root resorption of maxillary anterior teeth in adult orthodontic patients. Eur $\mathbf{J}$ Orthod, v.17, n.2, p.93-9, Apr. 1995.

95. MIRABELLA, A. D.; ARTUN, J. Risks factors for apical root resorption of maxillary anterior teeth in adult orthodontic patients. Am J Orthod Dentofac Orthop, v.108, n.1, p.48-55, July 1995.

96. MOYERS, R. E. Ortodontia. 4.ed. Rio de Janeiro, Guanabara, 1988. 
97. NEWMAN, W. G. Possible etiologic factors in external root resorption. Am J Orthod, v.67, n.5, p.522-39, May 1975.

98. NIELSEN, I. L. Facial growth during treatment with the function regulator appliance. Am J Orthod, v.85, n.2, p.401-10, May 1984.

99. O'BRIEN, K. et al. Effectiveness of early orthodontic treatment with the Twin-block appliance: a multicenter, randomized, controlled trial. Part 1: dental and skeletal effects. Am J Orthod Dentofac Orthop, v.124, n.3, p.234-43, Sep. 2003.

100. ODENRICK, I.; BRATISTRÖM, V. The effect of nailbiting on resorption during orthodontic treatment. Eur J Orthod, v.5, n.3, p.185-8, Aug. 1983.

101. OPPENHEIM, A. A possibility for physiologic orthodontic movement: theoretical part. Am J Orthod Oral Surg, v.30, n.6, p.277-32, June 1944.

102. OWEN, A. H. Maxillary incisolabial responses in Class II, div. 1 treatment with the Fränkel and Edgewise. Angle Orthod, v.56, n.1, p.67-78, Jan. 1986.

103. OWMAN-MOLL, P. Orthodontic tooth movement and root resorption with special reference to force magnitude and duration: a clinical and histological investigation adolescents. Swed Dent J Suppl, v.105, p.145, 1995.

104. OWMAN-MOLL, P.; KUROL, J.; LUNDGREN, D. Repair of orthodontically induced root resorption in adolescents. Angle Orthod, v.65, n.6, p.40310, 1995. 
105. OWMAN-MOLL, P.; KUROL, J.; LUNDGREN, D. Continuous versus interrupted continuous orthodontic force related to early tooth movement and root resorption. Angle Orthod, v.65, n.6, p.395-402, 1995.

106. PANCHERZ, H.; HÄGG, U. Dentofacial orthopedics in relation to somatic maturation: an analysis of 70 consecutive cases treated with the Herbst appliance. Am J Orthod, v.88, n.4, p.273-87, Oct. 1985.

107. PARKER, R. J.; HARRIS, E. F. Directions of orthodontic tooth movements associated with external apical root resorption of the maxillary central incisor. Am J Orthod Dentofac Orthop, v.114, n.6, p.673-83, Dec. 1998.

108. PEREIRA, A. C. J. Avaliação cefalométrica dos efeitos do guia de erupção no tratamento da má oclusão de Classe II, 1a divisão, após 10 meses, em jovens brasileiros, com idade média de 9 anos. Bauru, 1995. 151p. Dissertação (Mestrado) - Faculdade de Odontologia de Bauru, Universidade de São Paulo.

109. PHILLIPS, J. R. Apical root resorption under orthodontic therapy. Angle Orthod, v.25, n.1, p.1-22, Jan. 1955.

110. POURRAHIMI, P. Cephalometric evaluation of the correction of overbite and overjet with the eruption guidance appliance. Chicago, Illinois, 1982. 89p. Master Thesis - Northwestern University.

111. PROFFIT, W. R.; SELLERS, K. T. The effect of intermittent forces on eruption of the rabbit incisor. J Dent Res, v.65, n.22, p.118-22, Feb. 1986. 
112. QUINTELLA, C. G. Avaliação da influência do guia de erupção "Occlus-o-Guide", nos incisivos superiores e inferiores, com rizogênese incompleta. Bauru, 2001. 94p. Dissertação (Mestrado) Faculdade de Odontologia de Bauru, Universidade de São Paulo.

113. REITAN, K. Some factors determining the evaluation of forces in orthodontics. Am J Orthod, v.43, n.1, p.32-45, Jan. 1957.

114. REITAN, K. Initial tissue behavior during apical root resorption. Angle Orthod, v.44, n.1, p.68-82, Jan. 1974.

115. REITAN, K. Biochemical principles and reactions. In: GRABER, T.; SWAIN, B. Orthodontics principles and technics. St. Louis, Mosby, 1985. p.102-92.

116. REMINGTON, D. N. et al. Long-term evaluation of root resorption occurring during orthodontic treatment. Am J Orthod Dentofac Orthop, v.96, n.1, p.43-6, July 1989.

117. RIGHELLIS, E. G. Treatment effect of Fränkel, activator and extraoral traction appliances. Angle Orthod, v.33, n.2, p.107-21, Apr. 1983.

118. ROBERTSON, N. R. E. An examination of treatment changes in children treated with the funcion regulator of Fränkel. Am J Orthod, v.83, n.4, p.299-310, Apr. 1983.

119. RÖNNERMAN, A.; LARSSON, E. Overjet, overbite, intercanine distance and root resorption in orthodontically treated patients. Swed Dent J, v.5, n.1, p.21-7, Aug. 1981. 
120. ROSENBERG, M. N. An evaluation of the incidence and amount of apical root resorption and dilaceration occurring in orthodontically treated teeth having incompletely formed roots at the beginning of Begg treatment. Am J Orthod, v.61, n.5, p.524-5, May 1972.

121. RUDOLPH, C. E. A comparative study in root resorption in permanent teeth. J Am Dent Ass, v.23, n.5, p.822-6, May 1936.

122. RUDOLPH, C. E. An evaluation of root resorption ocurring during orthodontic treatment. J Dent Res, v.19, p.367-71, 1940.

123. RYGH, P. Orthodontic tooth resorption studied by electron microscopy. Angle Orthod, v.47, n.1, p.1-16, Jan. 1977.

124. SADOWSKY, P. L. Risk assessment and management in clinical orthodontics. Semin Orthod, v.8, n.4, p.185-260, 2002.

125. SAMESHIMA, G. T.; SINCLAIR, P. M. Predicting and preventing root resorption: part I. Diagnostic factors. Am J Orthod Dentofac Orthop, v.119, n.5, p.505-15, May 2001.

126. SAMESHIMA, G. T.; SINCLAIR, P. M. Predicting and preventing root resorption: part II. Treatment factors. Am J Orthod Dentofac Orthop, v.119, n.5, p.511-5, May 2001.

127. SEGAL, G. R.; SCHIFFMAN, P. H.; TUNCAY, O. C. Meta analysis of the treatment-related factors of external apical root resorption. Orthod Craniofacial Res, v.7, p.71-8, May 2004.

128. SERGL, H. G.; ZENTNER, A. A comparative assessment of acceptance os different types of functional appliances. Eur J Orthod, v.20, n.5, p.51724, Oct. 1998. 
129. SHARPE, W.; REED, B.; SUBTELNY, J. D. Orthodontic relapse, apical root resorption, and crestal alveolar bone levels. Am J Orthod Dentofac Orthop, v.91, n.3, p.252-8, Mar. 1987.

130. SIEGEL, S. Estatística não-paramétrica para as ciências do comportamento. Rio de Janeiro, McGraw-Hill do Brasil, 1975.

131. SLAKTER, M. J. et al. Reliability and stability of the orthodontic patient cooperation scale. Am J Orthod, v.78, n.5, p.559-63, Nov. 1980.

132. SOUZA, J. E. P. Comparação da proporção de sucesso de três modalidades de tratamento ortodôntico: Fränkel, Occlus-o-Guide e fixo, na correção da Classe II. Bauru, 2001. 156p. Dissertação (Mestrado) - Faculdade de Odontologia de Bauru, Universidade de São Paulo.

133. SPURRIER, S. W. et al. A comparison of apical root resorption during orthodontic treatment in endodontically treated and vital teeth. Am J Orthod Dentofac Orthop, v.97, n.2, p.130-4, Feb. 1990.

134. STEINER, C. C. The use of cephalometrics as an aid to planning and assessing orthodontic treatment. Am J Orthod, v.46, n.10, p.721-35, Oct. 1960.

135. STENVIK, A.; MJÖRK, I. A. Pulp and dentine reactions to experimental tooth intrusion. Am J Orthod, v.57, n.4, p.370-85, Apr. 1970.

136. STUTEVILLE, O. H. Injuries to the teeth and supporting structures caused by various orthodontic appliances and methods of preventing these injuries. J Am Dent Ass, v.14, p.1494-507, Sep. 1937. 
137. STUTEVILLE, O. H. Injuries caused by orthodontic forces and the ultimate results of these injuries. Am J Orthod Oral Surg, v.24, n.2, Feb. 1938.

138. TORUÑO, J. L. A. Alterações cefalométricas em jovens brasileiros, com Clase II, $1^{a}$ e $2^{a}$ divisões, tratados com o regulador de função de Fränkel. Avaliação após um ano de tratamento. Bauru, 1995. 112p. Dissertação (Mestrado) - Faculdade de Odontologia de Bauru, Universidade de São Paulo.

139. TULLOCH, J. F. C. et al. The effect of early intervention on skeletal pattern in Class II malocclusion: a randomized clinical trial. Am J Orthod Dentofac Orthop, v.111, n.4, p.391-400, Apr. 1997.

140. TULLOCH, J. F. C.; PHILLIPS, C.; PROFFIT, W. R. Benefit of early Class II treatment: progress report of a two-phase randomized clinical trial. Am J Orthod Dentofac Orthop, v.113, n.1, p.62-72, Jan. 1998.

141. ÜLGEN, M.; FIRATLI, S. The effects of the Frankel's function regulator on the class III malocclusion. Am J Orthod Dentofac Orthop, v.105, n.6, p.561-7, June 1994.

142. URSI, W. J. S. Alteração clínica da face em crescimento: uma comparação cefalométrica entre os aparelhos extrabucal cervical, Fränkel (FR2) e Herbst, no tratamento das más oclusões de Classe II, primeira divisão de Angle. Bauru, 1993. 168p. Tese (Doutorado) Faculdade de Odontologia de Bauru, Universidade de São Paulo.

143. VLASKALIC, V.; BOYD, R. L.; BAUMRIND, S. Etiology and sequelae of root resorption. Semin Orthod, v.4, n.2, p.124-31, Jun. 1998.

144. VONDERAHE, G. Postretention status of maxillary incisors with root-end resorption. Angle Orthod, v.43, n.3, p.247-55, July 1973. 
145. WEBSTER, T.; HARKNESS, M.; HERBISON, P. Associations between changes in selected facial dimensions and the outcome of orthodontic treatment. Am J Orthod Dentofac Orthop, v.110, n.1, p.46-53, July 1996.

146. WENZEL, A.; VERDONSCHOT, E. H. Some considerations in the evaluation of diagnostic tests in dentistry. Dentomaxillofac Radiol, v.23, n.4, p.179-82, Nov. 1994.

147. WOODSIDE, D. G. Do functional appliances have an orthopedic effect? Am J Orthod Dentofac Orthop, v.113, n.1, p.11-4, Jan. 1998.

148. YOSHII, O. New orthodontic device dynamic positioner (DP). I Approach to the proposal of DP and transparent silicone rubber. Nippon Dent Res, v.452, p.61-74, June 1980.

149. YUSOF, W. Z.; GHAZALI, M. N. Multiple external root resorption. J Am Dent Ass, v.118, n.4, p.453-5, Apr. 1989. 


\section{ABSTRACT}

A radiographic comparison of apical root resorption after treatment with Fränkel and Eruption Guidance appliances

The objective of this research was to comparatively evaluate the amount of apical root resorption of treatment conducted with two different removable appliances: the Fränkel Function Regulator and the Eruption Guidance Appliance, in relation to an untreated control group. Periapical radiographs were obtained after the end of treatment for the maxillary and mandibular incisors, with the long cone paralleling technique from 88 patients, divided into three groups. Group 1 consisted of 24 patients treated with the Fränkel appliance, group 2 consisted of 40 patients treated with the Eruption Guidance Appliance and group 3 comprised 24 untreated subjects. Root resorption was ranked by scores, according to the method of Levander \& Malmgren. The intraexaminer error was considered substantial or almost perfect by Kappa evaluation. Results of the Kuskal-Wallis test demonstrated statistically significant differences between the experimental groups and subgroups in relation to the control group. However, there was no statistically difference between the Fränkel and the Eruption Guidance Appliance. In the comparison between subgroups treated exclusively with removable appliances, and those that complemented treatment with fixed appliances, the Mann-Whitney test indicated greater resorption for the second. Considering the prevalence in the whole treated patients sample there was no root resorption in $23,25 \%$ of the analyzed teeth. Group 2 presented higher prevalence of resorption with slight to moderate degree, and group 1 presented accentuated root resorption in only 7,30\% of the analyzed teeth, corresponding to two patients. The prevalence of resorption for each incisor group indicated, in decreasing order, a larger resorption for the maxillary central, followed by the maxillary lateral, mandibular central and lastly, the mandibular lateral incisor. 
APÊNDICE 


\section{APÊNDICE}

Para uma melhor compreensão deste apêndice, sugere-se uma consulta à LISTA DE ABREVIATURAS, localizada na página xvi.

\section{TABELA 20}

Características gerais dos pacientes submetidos ao tratamento com o aparelho de Fränkel, exclusivamente

\begin{tabular}{|c|c|c|c|c|c|}
\hline $\begin{array}{c}\text { PACIENTES } \\
(\mathrm{n}=12)\end{array}$ & $\begin{array}{c}\text { GÊNERO } \\
(\mathrm{M}=8 ; \mathrm{F}=4)\end{array}$ & $\begin{array}{c}\text { IDADE } \\
\text { INICIAL }\end{array}$ & $\begin{array}{c}\text { IDADE } \\
\text { FINAL }\end{array}$ & $\begin{array}{c}\text { TEMPO } \\
\text { TRAT. }\end{array}$ & $\begin{array}{r}\text { PÓS- } \\
\text { TRAT }\end{array}$ \\
\hline A.G.S. & $\mathrm{M}$ & 11,52 & 14,26 & 2,75 & 0,00 \\
\hline A.C.G. & $\mathrm{F}$ & 10,11 & 12,04 & 1,93 & 0,00 \\
\hline A.S.C. & $\mathrm{M}$ & 10,19 & 12,13 & 1,93 & 8,92 \\
\hline C.N.G. & $\mathrm{F}$ & 8,55 & 11,68 & 3,13 & 0,04 \\
\hline F.H.P.M. & $\mathrm{M}$ & 7,79 & 12,54 & 4,75 & 6,14 \\
\hline H.C.R. & $\mathrm{M}$ & 8,40 & 13,56 & 5,16 & 0,00 \\
\hline H.O.F.S. & $\mathrm{M}$ & 10,95 & 13,96 & 3,01 & 0,00 \\
\hline J.C.G. & $\mathrm{F}$ & 10,11 & 13,87 & 3,76 & 7,15 \\
\hline L.R.Z. & $\mathrm{M}$ & 9,82 & 12,55 & 2,72 & 0,04 \\
\hline M.S.S. & $\mathrm{M}$ & 9,56 & 12,57 & 3,01 & 0,39 \\
\hline R.S.M. & $\mathrm{M}$ & 9,88 & 12,87 & 2,99 & 0,00 \\
\hline S.F.P. & $\mathrm{F}$ & 9,18 & 12,30 & 3,12 & 7,90 \\
\hline MÉDIA & & 9,67 & 12,86 & 3,18 & 2,54 \\
\hline DP $( \pm)$ & & 1,06 & 0,84 & 0,96 & 3,72 \\
\hline Mín./Máx. & & $7,78 / 11,51$ & $11,68 / 14,26$ & $1,93 / 5,15$ & $0,00 / 8,91$ \\
\hline
\end{tabular}




\section{TABELA 21}

Características gerais dos pacientes submetidos ao tratamento com o aparelho de Fränkel e o aparelho fixo

\begin{tabular}{|c|c|c|c|c|c|c|}
\hline $\begin{array}{l}\text { PACIENTES } \\
(n=12)\end{array}$ & $\begin{array}{l}\text { GÊNERO } \\
(\mathrm{M}=6 ; \mathrm{F}=6)\end{array}$ & $\begin{array}{l}\text { IDADE } \\
\text { INICIAL } \\
\text { (FR) }\end{array}$ & $\begin{array}{l}\text { IDADE } \\
\text { FINAL } \\
(F R)\end{array}$ & $\begin{array}{c}\text { TEMPO } \\
\text { TRAT. } \\
\text { (FR) }\end{array}$ & $\begin{array}{l}\text { TEMPO } \\
\text { TRAT. } \\
\text { (FIXO) }\end{array}$ & $\begin{array}{l}\text { PÓS- } \\
\text { TRAT. }\end{array}$ \\
\hline A.C.C. & $F$ & 10,39 & 13,64 & 3,25 & 1,38 & 6,61 \\
\hline C.T.V. & $\mathrm{F}$ & 9,66 & 12,86 & 3,20 & 0,88 & 3,79 \\
\hline I.P.G. & $F$ & 10,02 & 13,22 & 3,20 & 4,11 & 0,01 \\
\hline J.T. & $F$ & 10,67 & 12,46 & 1,79 & 1,26 & 3,55 \\
\hline L.L.M. & M & 7,56 & 9,40 & 1,84 & 1,61 & 2,71 \\
\hline O.Z.M. & $M$ & 9,93 & 12,72 & 2,79 & 1,05 & 3,79 \\
\hline R.M.C. & M & 8,81 & 11,49 & 2,68 & 1,74 & 6,15 \\
\hline R.M.A. & M & 10,31 & 11,33 & 1,01 & 1,23 & 0,19 \\
\hline S.R.L. & $\mathrm{F}$ & 11,17 & 13,65 & 2,48 & 1,58 & 5,79 \\
\hline S.P.C. & $F$ & 12,01 & 14,96 & 2,95 & 2,33 & 5,10 \\
\hline V.C. & M & 6,32 & 8,15 & 1,84 & 0,67 & 7,47 \\
\hline Y.Y. & M & 9,88 & 10,81 & 0,92 & 2,26 & 5,72 \\
\hline MÉDIA & & 9,72 & 12,05 & 2,32 & 1,67 & 4,23 \\
\hline $\mathrm{DP}( \pm)$ & & 1,54 & 1,92 & 0,83 & 0,91 & 2,38 \\
\hline Mín./Máx. & & $6,31 / 12,00$ & $8,15 / 14,95$ & $0,92 / 3,25$ & $0,67 / 4,10$ & $0,01 / 7,46$ \\
\hline
\end{tabular}


TABELA 22

Características gerais dos pacientes submetidos ao tratamento com os Guias de Erupção, exclusivamente

\begin{tabular}{|c|c|c|c|c|c|}
\hline $\begin{array}{l}\text { PACIENTES } \\
(n=28)\end{array}$ & $\begin{array}{c}\text { GÊNERO } \\
(\mathrm{M}=15 ; \mathrm{F}=13)\end{array}$ & $\begin{array}{l}\text { IDADE } \\
\text { INICIAL }\end{array}$ & $\begin{array}{l}\text { IDADE } \\
\text { FINAL }\end{array}$ & $\begin{array}{l}\text { TEMPO } \\
\text { TRAT. }\end{array}$ & $\begin{array}{l}\text { PÓS- } \\
\text { TRAT. }\end{array}$ \\
\hline A.R.S.J. & M & 9,88 & 11,61 & 1,73 & 5,28 \\
\hline A.C.M.M. & $\mathrm{F}$ & 9,90 & 12,76 & 2,86 & 7,62 \\
\hline C.S.M. & $\mathrm{F}$ & 6,62 & 9,01 & 2,39 & 4,76 \\
\hline G.R.C. & M & 8,65 & 9,53 & 0,88 & 9,62 \\
\hline G.M.G. & $\mathrm{F}$ & 8,18 & 14,69 & 6,51 & 0,64 \\
\hline G.D.S. & M & 6,72 & 12,54 & 5,82 & 1,33 \\
\hline K.L.P. & $\mathrm{F}$ & 9,09 & 14,32 & 5,23 & 5,24 \\
\hline M.R.G. & M & 10,09 & 13,42 & 3,33 & 7,12 \\
\hline O.M.J. & M & 9,78 & 11,84 & 2,06 & 8,46 \\
\hline R.A.B. & M & 8,46 & 10,15 & 1,69 & 5,29 \\
\hline R.J.G. & M & 9,92 & 17,07 & 7,15 & 0,00 \\
\hline T.C.B. & $M$ & 9,33 & 10,94 & 1,61 & 5,56 \\
\hline V.F.S. & M & 7,51 & 12,29 & 4,78 & 2,27 \\
\hline Y.B.A. & M & 9,20 & 13,78 & 4,58 & 2,57 \\
\hline A.D.B.C. & M & 6,24 & 11,73 & 5,50 & 1,42 \\
\hline B.C.A. & $\mathrm{F}$ & 6,38 & 9,16 & 2,78 & 7,86 \\
\hline C.P.O. & $\mathrm{F}$ & 7,35 & 9,01 & 1,67 & 5,29 \\
\hline D.V.S. & $\mathrm{F}$ & 9,64 & 10,50 & 0,86 & 9,77 \\
\hline D.C.P. & M & 7,80 & 12,59 & 4,79 & 5,66 \\
\hline J.C.L. & $\mathrm{F}$ & 7,65 & 14,39 & 6,74 & 0,28 \\
\hline K.M.M. & F & 8,39 & 12,70 & 4,32 & 1,87 \\
\hline L.B.A. & $\mathrm{F}$ & 7,31 & 10,16 & 2,85 & 7,66 \\
\hline N.C.F. & F & 8,68 & 9,53 & 0,84 & 9,63 \\
\hline T.C.Z. & $\mathrm{F}$ & 6,23 & 13,85 & 7,62 & 3,01 \\
\hline V.G.P. & M & 6,65 & 11,23 & 4,58 & 2,57 \\
\hline M.A.M. & $F$ & 8,59 & 14,26 & 5,67 & 1,33 \\
\hline P.A.O. & M & 6,51 & 11,75 & 5,23 & 1,77 \\
\hline T.M. & M & 5,93 & 13,08 & 7,15 & 0,00 \\
\hline MÉDIA & & 8,09 & 12,06 & 3,97 & 4,42 \\
\hline $\mathrm{DP}( \pm)$ & & 1,34 & 2,01 & 2,12 & 3,16 \\
\hline Mín./Máx. & & $5,93 / 10,08$ & $9,01 / 17,06$ & & $0,00 / 9,76$ \\
\hline
\end{tabular}




\section{TABELA 23}

Características gerais dos pacientes submetidos ao tratamento com os Guias de Erupção e o aparelho fixo

\begin{tabular}{|c|c|c|c|c|c|c|}
\hline $\begin{array}{l}\text { PACIENTES } \\
(n=12)\end{array}$ & $\begin{array}{l}\text { GÊNERO } \\
(\mathrm{M}=3 ; \mathrm{F}=9)\end{array}$ & $\begin{array}{l}\text { IDADE } \\
\text { INICIAL } \\
(\mathrm{OG})\end{array}$ & $\begin{array}{l}\text { IDADE } \\
\text { FINAL } \\
(\mathrm{OG})\end{array}$ & $\begin{array}{c}\text { TEMPO } \\
\text { TRAT. } \\
\text { (OG) }\end{array}$ & $\begin{array}{l}\text { TEMPO } \\
\text { TRAT. } \\
\text { (FIXO) }\end{array}$ & $\begin{array}{l}\text { PÓS- } \\
\text { TRAT. }\end{array}$ \\
\hline A.L.L. & $F$ & 8,41 & 12,03 & 3,62 & 3,67 & 1,63 \\
\hline B.G.A. & $F$ & 8,61 & 12,42 & 3,82 & 1,60 & 0,00 \\
\hline C.C.M. & $F$ & 9,24 & 11,48 & 2,24 & 0,92 & 4,85 \\
\hline F.R.S. & $F$ & 11,06 & 14,95 & 3,89 & 3,83 & 2,45 \\
\hline L.G.R. & M & 9,82 & 13,41 & 3,58 & 1,51 & 3,89 \\
\hline M.S.C. & $F$ & 8,62 & 13,92 & 5,31 & 0,59 & 4,64 \\
\hline P.Z. & $F$ & 8,55 & 10,95 & 2,39 & 1,51 & 3,89 \\
\hline R.C.C. & M & 8,23 & 14,51 & 6,28 & 0,56 & 4,35 \\
\hline F.H.P. & $M$ & 8,96 & 14,24 & 5,28 & 2,11 & 3,07 \\
\hline G.C.R. & $F$ & 6,07 & 11,17 & 5,10 & 1,37 & 0,52 \\
\hline G.B.F. & $F$ & 5,84 & 8,23 & 2,39 & 0,67 & 5,14 \\
\hline L.R.G. & $F$ & 7,07 & 12,12 & 5,05 & 1,90 & 0,00 \\
\hline MÉDIA & & 8,37 & 12,45 & 4,07 & 1,68 & 2,87 \\
\hline $\mathrm{DP}( \pm)$ & & 1,47 & 1,90 & 1,32 & 1,08 & 1,91 \\
\hline Mín./Máx. & & $5,84 / 11,05$ & $8,23 / 14,95$ & $2,24 / 6,28$ & $0,55 / 3,83$ & $0,00 / 5,13$ \\
\hline
\end{tabular}


TABELA 24

Características gerais do grupo controle

\begin{tabular}{|c|c|c|}
\hline $\begin{array}{c}\text { PACIENTES } \\
(\mathrm{n}=24)\end{array}$ & $\begin{array}{c}\text { GÊNERO } \\
(\mathrm{M}=12 ; \mathrm{F}=12)\end{array}$ & IDADE RX \\
\hline A.A. & $\mathrm{F}$ & 14 \\
\hline E.A.T. & $\mathrm{F}$ & 14 \\
\hline E.F.C. & $\mathrm{M}$ & 14 \\
\hline E.F.S.R. & $\mathrm{M}$ & 19 \\
\hline F.H.G. & $\mathrm{F}$ & 15 \\
\hline G.A.P.B. & $\mathrm{M}$ & 14 \\
\hline J.A.A.E. & $\mathrm{M}$ & 16 \\
\hline J.V.S.V. & $\mathrm{M}$ & 14 \\
\hline M.F. & $\mathrm{F}$ & 13 \\
\hline M.F.D.D.F. & $\mathrm{M}$ & 18 \\
\hline M.G.B.Z. & $\mathrm{M}$ & 15 \\
\hline M.N.J. & $\mathrm{F}$ & 15 \\
\hline M.S.C. & $\mathrm{M}$ & 15 \\
\hline N.I.A.Jr. & $\mathrm{M}$ & 17 \\
\hline R.I. & $\mathrm{F}$ & 15 \\
\hline V.J. & $\mathrm{F}$ & 19 \\
\hline A.M.P. & $\mathrm{F}$ & 26,07 \\
\hline D.D.M. & $\mathrm{F}$ & 16,18 \\
\hline G.A.B. & $\mathrm{F}$ & 18,73 \\
\hline N.L.A. & $\mathrm{F}$ & 18,03 \\
\hline R.S.M. & $\mathrm{M}$ & 20,69 \\
\hline R.A.R. & $\mathrm{M}$ & 19,15 \\
\hline R.R.R. & $\mathrm{M}$ & 21,19 \\
\hline M.C.N.C.M. & $\mathrm{F}$ & \\
\hline DP & & \\
\hline M. & & $13,00 / 26,07$ \\
\hline
\end{tabular}




\section{TABELA 25}

Escores de reabsorção radicular encontrado no grupo 1

\begin{tabular}{|c|c|c|c|c|c|c|c|c|c|}
\hline $\begin{array}{l}\text { PACIENTES } \\
(n=24)\end{array}$ & D12 & D11 & D21 & D22 & D42 & D41 & D31 & D32 & DM \\
\hline A.G.S. & 0 & 0 & 0 & 0 & 0 & 1 & 1 & 0 & 0,250 \\
\hline A.C.G. & 2 & 2 & 2 & 2 & 1 & 0 & 1 & 1 & 1,375 \\
\hline A.S.C. & 2 & 1 & 1 & 1 & 1 & 1 & 1 & 1 & 1,125 \\
\hline C.N.G. & 1 & 1 & 1 & 1 & 0 & 1 & 1 & 0 & 0,750 \\
\hline F.H.P.M. & 1 & 1 & 1 & 1 & 0 & 1 & 2 & 0 & 0,875 \\
\hline H.C.R. & 0 & 0 & 1 & 0 & 1 & 0 & 0 & 1 & 0,375 \\
\hline H.O.F.S. & 0 & 0 & 0 & 0 & 0 & 1 & 1 & 0 & 0,250 \\
\hline J.C.G. & 2 & 0 & 0 & 0 & 0 & 0 & 2 & 0 & 0,500 \\
\hline L.R.Z. & 0 & 0 & 0 & 0 & 1 & 0 & 0 & 0 & 0,125 \\
\hline M.S.S. & 1 & 1 & 1 & 1 & 1 & 1 & 1 & 1 & 1,000 \\
\hline R.S.M. & 1 & 1 & 1 & 0 & 1 & 1 & 1 & 0 & 0,750 \\
\hline S.F.P. & 1 & 1 & 1 & 1 & 1 & 0 & 0 & 0 & 0,625 \\
\hline A.C.C. & 2 & 2 & 2 & 2 & 1 & 1 & 2 & 1 & 1,625 \\
\hline C.T.V. & 1 & 1 & 1 & 1 & 1 & 0 & 0 & 0 & 0,625 \\
\hline I.P.G. & 3 & 3 & 2 & 3 & 1 & 0 & 0 & 2 & 1,750 \\
\hline J.T. & 2 & 2 & 2 & 2 & 1 & 2 & 2 & 2 & 1,875 \\
\hline L.L.M. & 1 & 1 & 1 & 0 & 0 & 0 & 0 & 1 & 0,500 \\
\hline O.Z.M. & 2 & 1 & 1 & 2 & 1 & 0 & 0 & 0 & 0,875 \\
\hline R.M.C. & 1 & 1 & 1 & 1 & 1 & 1 & 1 & 1 & 1,000 \\
\hline R.M.A. & 1 & 1 & 1 & 2 & 2 & 2 & 1 & 1 & 1,375 \\
\hline S.R.L. & 2 & 2 & 2 & 2 & 1 & 2 & 2 & 1 & 1,750 \\
\hline S.P.C. & 1 & 1 & 1 & 1 & 1 & 2 & 1 & 1 & 1,125 \\
\hline V.C. & 1 & 1 & 1 & 1 & 0 & 1 & 1 & 0 & 0,750 \\
\hline Y.Y. & 2 & 3 & 3 & 3 & 2 & 2 & 2 & 3 & 2,500 \\
\hline
\end{tabular}


TABELA 26

Escores de reabsorção radicular encontrado no grupo 2

\begin{tabular}{|c|c|c|c|c|c|c|c|c|c|}
\hline $\begin{array}{l}\text { PACIENTES } \\
(n=40)\end{array}$ & D12 & D11 & D21 & D22 & D42 & D41 & D31 & D32 & DM \\
\hline A.R.S.J. & 2 & 1 & 1 & 1 & 1 & 1 & 1 & 1 & 1,125 \\
\hline A.C.M.M. & 1 & 1 & 1 & 1 & 0 & 1 & 1 & 0 & 0,750 \\
\hline C.S.M. & 0 & 1 & 1 & 0 & 0 & 1 & 1 & 1 & 0,625 \\
\hline G.R.C. & 1 & 1 & 1 & 1 & 0 & 1 & 1 & 1 & 0,875 \\
\hline G.M.G. & 0 & 1 & 1 & 0 & 1 & 1 & 1 & 1 & 0,750 \\
\hline G.D.S. & 1 & 2 & 1 & 1 & 1 & 0 & 0 & 1 & 0,875 \\
\hline K.L.P. & 1 & 1 & 1 & 1 & 1 & 2 & 1 & 1 & 1,125 \\
\hline M.R.G. & 1 & 1 & 1 & 0 & 1 & 1 & 1 & 1 & 0,875 \\
\hline O.M.J. & 1 & 1 & 1 & 1 & 1 & 2 & 2 & 1 & 1,250 \\
\hline R.A.B. & 1 & 1 & 1 & 1 & 0 & 1 & 1 & 1 & 0,875 \\
\hline R.J.G. & 0 & 1 & 0 & 0 & 0 & 1 & 0 & 0 & 0,250 \\
\hline T.C.B. & 1 & 1 & 1 & 1 & 0 & 1 & 1 & 1 & 0,875 \\
\hline V.F.S. & 1 & 1 & 1 & 1 & 1 & 1 & 1 & 1 & 1,000 \\
\hline Y.B.A. & 1 & 1 & 1 & 1 & 0 & 0 & 0 & 0 & 0,500 \\
\hline A.D.B.C. & 1 & 2 & 1 & 1 & 1 & 1 & 1 & 1 & 1,125 \\
\hline B.C.A. & 1 & 1 & 1 & 2 & 0 & 1 & 1 & 1 & 1,000 \\
\hline C.P.O. & 0 & 0 & 0 & 1 & 0 & 0 & 0 & 0 & 0,125 \\
\hline D.V.S. & 1 & 1 & 1 & 1 & 1 & 1 & 1 & 1 & 1,000 \\
\hline D.C.P. & 1 & 1 & 1 & 2 & 1 & 2 & 2 & 1 & 1,375 \\
\hline J.C.L. & 1 & 1 & 1 & 1 & 1 & 1 & 1 & 1 & 1,000 \\
\hline K.M.M. & 1 & 1 & 1 & 1 & 1 & 2 & 1 & 2 & 1,250 \\
\hline L.B.A. & 1 & 2 & 1 & 1 & 1 & 0 & 1 & 1 & 1,000 \\
\hline N.C.F. & 2 & 1 & 1 & 1 & 1 & 0 & 1 & 1 & 1,000 \\
\hline T.C.Z. & 1 & 1 & 1 & 1 & 1 & 1 & 1 & 1 & 1,000 \\
\hline V.G.P. & 1 & 1 & 1 & 1 & 0 & 1 & 1 & 0 & 0,750 \\
\hline M.A.M. & 0 & 1 & 1 & 0 & 1 & 1 & 1 & 0 & 0,625 \\
\hline P.A.O. & 1 & 1 & 1 & 1 & 1 & 0 & 0 & 0 & 0,625 \\
\hline T.M. & 1 & 1 & 0 & 1 & 1 & 1 & 1 & 0 & 0,750 \\
\hline A.L.L. & 1 & 1 & 1 & 1 & 1 & 1 & 1 & 1 & 1,000 \\
\hline B.G.A. & 0 & 1 & 0 & 0 & 0 & 0 & 1 & 0 & 0,250 \\
\hline C.C.M. & 1 & 1 & 1 & 1 & 1 & 1 & 1 & 1 & 1,000 \\
\hline F.R.S. & 1 & 2 & 1 & 1 & 1 & 2 & 2 & 1 & 1,375 \\
\hline L.G.R. & 1 & 0 & 0 & 1 & 0 & 2 & 0 & 0 & 0,500 \\
\hline M.S.C. & 2 & 2 & 2 & 2 & 1 & 1 & 1 & 1 & 1,500 \\
\hline P.Z. & 1 & 1 & 1 & 1 & 1 & 1 & 1 & 0 & 0,875 \\
\hline R.C.C. & 1 & 2 & 2 & 2 & 1 & 2 & 2 & 1 & 1,625 \\
\hline F.H.P. & 2 & 1 & 1 & 2 & 1 & 1 & 2 & 2 & 1,500 \\
\hline G.C.R. & 1 & 1 & 1 & 1 & 0 & 1 & 1 & 1 & 0,875 \\
\hline G.B.F. & 0 & 0 & 0 & 0 & 1 & 0 & 0 & 1 & 0,250 \\
\hline L.R.G. & 1 & 1 & 1 & 0 & 0 & 1 & 1 & 0 & 0,625 \\
\hline
\end{tabular}




\section{TABELA 27}

Escores de reabsorção radicular encontrado no grupo 3

\begin{tabular}{|c|c|c|c|c|c|c|c|c|c|}
\hline $\begin{array}{l}\text { PACIENTES } \\
(n=24)\end{array}$ & D12 & D11 & D21 & D22 & D42 & D41 & D31 & D32 & DM \\
\hline A.A. & 0 & 0 & 0 & 0 & 0 & 0 & 0 & 0 & 0,000 \\
\hline E.A.T. & 1 & 1 & 1 & 1 & 1 & 1 & 1 & 0 & 0,875 \\
\hline E.F.C. & 0 & 0 & 0 & 0 & 0 & 0 & 0 & 0 & 0,000 \\
\hline E.F.S.R. & 1 & 1 & 2 & 1 & 1 & 1 & 1 & 1 & 1,125 \\
\hline F.H.G. & 1 & 0 & 0 & 1 & 0 & 1 & 0 & 0 & 0,375 \\
\hline G.A.P.B. & 1 & 1 & 1 & 0 & 1 & 0 & 0 & 1 & 0,625 \\
\hline J.A.A.E. & 1 & 1 & 1 & 1 & 1 & 1 & 1 & 1 & 1,000 \\
\hline J.V.S.V. & 0 & 0 & 0 & 0 & 0 & 1 & 1 & 0 & 0,250 \\
\hline M.F. & 0 & 0 & 0 & 1 & 0 & 0 & 0 & 0 & 0,125 \\
\hline M.F.D.D.F. & 0 & 0 & 0 & 0 & 1 & 0 & 0 & 2 & 0,375 \\
\hline M.G.B.Z. & 0 & 0 & 0 & 0 & 0 & 0 & 1 & 0 & 0,125 \\
\hline M.N.J. & 0 & 0 & 0 & 0 & 0 & 0 & 0 & 0 & 0,000 \\
\hline M.S.C. & 0 & 0 & 0 & 0 & 0 & 0 & 0 & 0 & 0,000 \\
\hline N.I.A.Jr. & 0 & 0 & 0 & 0 & 0 & 0 & 0 & 0 & 0,000 \\
\hline R.I. & 0 & 1 & 0 & 0 & 0 & 0 & 0 & 0 & 0,125 \\
\hline V.J. & 1 & 0 & 0 & 0 & 1 & 1 & 1 & 1 & 0,625 \\
\hline A.M.P. & 0 & 1 & 0 & 1 & 0 & 0 & 0 & 0 & 0,250 \\
\hline D.D.M. & 1 & 2 & 2 & 1 & 0 & 1 & 1 & 0 & 1,000 \\
\hline G.A.B. & 0 & 0 & 0 & 0 & 0 & 0 & 0 & 0 & 0,000 \\
\hline N.L.A. & 0 & 0 & 0 & 0 & 0 & 0 & 0 & 0 & 0,000 \\
\hline R.S.M. & 1 & 1 & 2 & 1 & 0 & 0 & 0 & 0 & 0,625 \\
\hline R.A.R. & 2 & 0 & 0 & 1 & 0 & 1 & 0 & 0 & 0,500 \\
\hline R.R.R. & 1 & 0 & 0 & 2 & 0 & 1 & 0 & 0 & 0,500 \\
\hline S.C.N.C.M. & 1 & 1 & 1 & 0 & 0 & 1 & 1 & 0 & 0,625 \\
\hline
\end{tabular}




\section{TABELA 28}

Repetições da avaliação de reabsorção radicular nos incisivos superiores, em escores, de 30 pacientes escolhidos aleatoriamente

\begin{tabular}{|c|c|c|c|c|c|c|c|c|}
\hline \multirow{2}{*}{$\begin{array}{l}\text { PACIENTES } \\
(n=30)\end{array}$} & \multicolumn{2}{|c|}{ D12 } & \multicolumn{2}{|c|}{ D11 } & \multicolumn{2}{|c|}{ D21 } & \multicolumn{2}{|c|}{ D22 } \\
\hline & $1^{\mathrm{a}}{ }_{\text {medição }}$ & $\begin{array}{c}2^{\mathrm{a}} \\
\text { medição }\end{array}$ & $\begin{array}{c}1^{\mathrm{a}} \\
\text { medição }\end{array}$ & $\begin{array}{c}2^{\mathrm{a}} \\
\text { medição }\end{array}$ & $1^{\mathrm{a}}$ & $\begin{array}{c}2^{\mathrm{a}} \\
\text { medição }\end{array}$ & $\begin{array}{c}1^{\mathrm{a}} \\
\text { medição }\end{array}$ & $\begin{array}{c}2^{\mathrm{a}} \\
\text { medição }\end{array}$ \\
\hline A.A. & 0 & 0 & 0 & 0 & 0 & 0 & 0 & 0 \\
\hline E.F.C. & 0 & 1 & 0 & 0 & 0 & 0 & 0 & 0 \\
\hline E.F.S.R. & 1 & 1 & 1 & 1 & 2 & 2 & 1 & 1 \\
\hline F.H.G. & 1 & 1 & 0 & 0 & 0 & 0 & 1 & 0 \\
\hline M.G.B.Z. & 0 & 0 & 0 & 0 & 0 & 0 & 0 & 0 \\
\hline M.N.J. & 0 & 0 & 0 & 0 & 0 & 1 & 0 & 0 \\
\hline M.S.C. & 0 & 0 & 0 & 0 & 0 & 0 & 0 & 0 \\
\hline R.C.F. & 0 & 0 & 1 & 1 & 1 & 1 & 0 & 1 \\
\hline R.I. & 0 & 0 & 1 & 0 & 0 & 1 & 0 & 0 \\
\hline V.J. & 1 & 1 & 0 & 1 & 0 & 1 & 0 & 1 \\
\hline A.S.C. & 2 & 3 & 1 & 1 & 1 & 1 & 1 & 1 \\
\hline H.C.R. & 0 & 0 & 0 & 0 & 1 & 1 & 0 & 0 \\
\hline H.O.F.S. & 0 & 0 & 0 & 0 & 0 & 0 & 0 & 0 \\
\hline I.P.G. & 3 & 3 & 3 & 3 & 2 & 2 & 3 & 3 \\
\hline J.T. & 2 & 2 & 2 & 2 & 2 & 2 & 2 & 2 \\
\hline L.L.M. & 1 & 1 & 1 & 1 & 1 & 1 & 0 & 0 \\
\hline O.Z.M. & 2 & 2 & 1 & 1 & 1 & 1 & 2 & 2 \\
\hline R.M.C. & 1 & 1 & 1 & 1 & 1 & 1 & 1 & 1 \\
\hline R.M.A. & 1 & 1 & 1 & 1 & 1 & 1 & 2 & 2 \\
\hline S.R.L. & 2 & 2 & 2 & 2 & 2 & 2 & 2 & 2 \\
\hline A.R.S.J. & 2 & 2 & 1 & 1 & 1 & 1 & 1 & 1 \\
\hline A.C.M.M. & 1 & 1 & 1 & 1 & 1 & 1 & 1 & 1 \\
\hline A.L.L. & 1 & 1 & 2 & 2 & 1 & 2 & 1 & 1 \\
\hline B.G.A. & 1 & 1 & 1 & 1 & 1 & 1 & 2 & 2 \\
\hline B.C.A. & 1 & 1 & 1 & 1 & 1 & 1 & 1 & 1 \\
\hline C.P.O. & 1 & 1 & 1 & 1 & 1 & 1 & 1 & 1 \\
\hline D.V.S. & 0 & 1 & 1 & 2 & 1 & 1 & 0 & 1 \\
\hline T.C.Z. & 1 & 1 & 2 & 2 & 1 & 1 & 1 & 1 \\
\hline V.G.P. & 1 & 1 & 0 & 1 & 0 & 1 & 1 & 1 \\
\hline G.C.R. & 1 & 1 & 1 & 2 & 1 & 1 & 1 & 1 \\
\hline
\end{tabular}




\section{TABELA 29}

Repetições da avaliação de reabsorção radicular nos incisivos inferiores, em escores, de 30 pacientes escolhidos aleatoriamente

\begin{tabular}{|c|c|c|c|c|c|c|c|c|}
\hline \multirow{2}{*}{$\begin{array}{l}\text { PACIENTES } \\
(n=30)\end{array}$} & \multicolumn{2}{|c|}{ D42 } & \multicolumn{2}{|c|}{ D41 } & \multicolumn{2}{|c|}{ D31 } & \multicolumn{2}{|c|}{ D32 } \\
\hline & $\begin{array}{c}1^{\mathrm{a}} \\
\text { medição }\end{array}$ & $\begin{array}{c}2^{\mathrm{a}} \\
\text { medição }\end{array}$ & $\begin{array}{c}1^{\mathrm{a}} \\
\text { medição }\end{array}$ & $\begin{array}{c}2^{\mathrm{a}} \\
\text { medição }\end{array}$ & $\stackrel{1}{\mathrm{a}}_{\text {medição }}$ & $\begin{array}{c}2^{\mathrm{a}} \\
\text { medição }\end{array}$ & $\begin{array}{c}1^{\mathrm{a}} \\
\text { medição }\end{array}$ & $\begin{array}{c}2^{\mathrm{a}} \\
\text { medição }\end{array}$ \\
\hline A.A. & 0 & 0 & 0 & 0 & 0 & 0 & 0 & 0 \\
\hline E.F.C. & 0 & 1 & 0 & 0 & 0 & 0 & 0 & 0 \\
\hline E.F.S.R. & 1 & 1 & 1 & 1 & 1 & 0 & 1 & 1 \\
\hline F.H.G. & 0 & 0 & 1 & 0 & 0 & 0 & 0 & 0 \\
\hline M.G.B.Z. & 0 & 0 & 0 & 0 & 1 & 1 & 0 & 0 \\
\hline M.N.J. & 0 & 0 & 0 & 0 & 0 & 0 & 0 & 0 \\
\hline M.S.C. & 0 & 0 & 0 & 0 & 0 & 0 & 0 & 0 \\
\hline R.C.F. & 1 & 1 & 1 & 1 & 1 & 1 & 1 & 1 \\
\hline R.I. & 0 & 0 & 0 & 0 & 0 & 0 & 0 & 0 \\
\hline V.J. & 1 & 1 & 1 & 1 & 1 & 1 & 1 & 0 \\
\hline A.S.C. & 1 & 1 & 1 & 1 & 1 & 1 & 1 & 2 \\
\hline H.C.R. & 1 & 1 & 0 & 1 & 0 & 0 & 1 & 0 \\
\hline H.O.F.S. & 0 & 0 & 1 & 1 & 1 & 0 & 0 & 0 \\
\hline I.P.G. & 1 & 1 & 0 & 0 & 0 & 0 & 2 & 2 \\
\hline J.T. & 1 & 1 & 2 & 2 & 2 & 2 & 2 & 2 \\
\hline L.L.M. & 0 & 0 & 0 & 0 & 0 & 0 & 1 & 0 \\
\hline O.Z.M. & 1 & 1 & 0 & 0 & 0 & 0 & 0 & 0 \\
\hline R.M.C. & 1 & 1 & 1 & 1 & 1 & 1 & 1 & 1 \\
\hline R.M.A. & 2 & 2 & 2 & 2 & 1 & 1 & 1 & 1 \\
\hline S.R.L. & 1 & 2 & 2 & 2 & 2 & 2 & 1 & 1 \\
\hline A.R.S.J. & 1 & 1 & 1 & 2 & 1 & 1 & 1 & 1 \\
\hline A.C.M.M. & 0 & 1 & 1 & 1 & 1 & 1 & 0 & 1 \\
\hline A.L.L. & 1 & 1 & 1 & 1 & 1 & 1 & 1 & 1 \\
\hline B.G.A. & 0 & 1 & 1 & 1 & 1 & 1 & 1 & 1 \\
\hline B.C.A. & 1 & 1 & 1 & 1 & 1 & 1 & 1 & 1 \\
\hline C.P.O. & 0 & 0 & 1 & 1 & 1 & 1 & 0 & 0 \\
\hline D.V.S. & 1 & 1 & 1 & 1 & 1 & 1 & 0 & 0 \\
\hline T.C.Z. & 1 & 1 & 2 & 2 & 2 & 2 & 1 & 1 \\
\hline V.G.P. & 0 & 0 & 2 & 1 & 0 & 1 & 0 & 0 \\
\hline G.C.R. & 1 & 1 & 1 & 1 & 1 & 1 & 0 & 0 \\
\hline
\end{tabular}




\section{Universidade de São Paulo \\ Faculdade de Odontologia de Bauru \\ Al. Dr. Octávio Pinheiro Brisolla, 9-75 - Bauru-SP - CEP 17012-901 - C.P. 73 \\ PABX (0XX14)3235-8000 - FAX (0XX14)3223-4679 \\ Comitê de Ética em Pesquisa}

Processo n ${ }^{\circ} 100 / 2004$

Bauru, 09 de agosto de 2004.

Senhor Professor,

O projeto de pesquisa encaminhado a este Comitê de Ética em Pesquisa em Seres Humanos, denominado "Avaliação comparativa da reabsorção radicular apical em pacientes tratados com 0 regulador funcional de Fränkel e 0 aparelho guia de erupção", de autoria de Alexandre Yudy Nakamura, que será desenvolvido sob sua orientação, foi enviado ao relator para avaliação.

Na reunião de 05 de agosto de 2004 o parecer do relator, aprovando o projeto, foi aceito pelo Comitê, considerando que não existem infrações éticas pendentes.

Informamos que após o envio do trabalho concluido, este Comitê enviará o parecer final, que será utilizado para publicação do trabalho.

Atenciosamente,

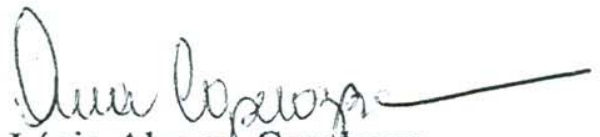

Prof ${ }^{a} r^{a}$ Ana Lúcia Alvares Capelozza

Coordenadora 